Analysis of local livelihoods from past to present in the Central Kalimantan ex-mega rice project area

Suyanto, Noviana Khususiyah, Idris Sardi,

Yana Buana and Meine van Noordwijk 



\section{Analysis of local livelihoods from past to present in the Central Kalimantan ex-mega rice project area}

Suyanto, Noviana Khususiyah, Idris Sardi, Yana Buana and Meine van Noordwijk 


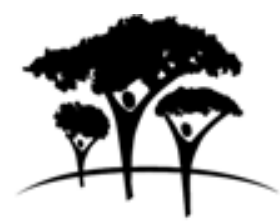

World Agroforestry Centre

TRANSFORMING LIVES AND LANDSCAPES

\section{Correct citation:}

Suyanto, Noviana Khususiyah, Idris Sardi, Yana Buana and Meine van Noordwijk. 2009. Analysis of local livelihoods from past to present in the Central Kalimantan ex-mega rice project area. Working paper 94. World Agroforestry Centre. Bogor, Indonesia. 70p

Titles in the Working Paper Series aim to disseminate interim results on agroforestry research and practices and stimulate feedback from the scientific community. Other publication series from the World Agroforestry Centre include: Agroforestry Perspectives, Technical Manuals and Occasional Papers.

Published by

World Agroforestry Centre

ICRAF Southeast Asia Regional Office

PO Box 161, Bogor 16001, Indonesia

Tel: +622518625415

Fax: +622518625416

Email: icraf-indonesia@cgiar.org

http://www.worldagroforestrycentre.org/sea

(C) World Agroforestry Centre 2009

Working Paper nr 94

The views expressed in this publication are those of the author(s) and not necessarily those of the World Agroforestry Centre.

Articles appearing in this publication may be quoted or reproduced without charge, provided the source is acknowledged.

All images remain the sole property of their source and may not be used for any purpose without written permission of the source. 


\section{Summary}

Indonesia is a prime target for international efforts to reduce greenhouse gas emissions from land use and land use change sectors, since the country is known to be a global leader in such emissions, ranking third in overall greenhouse gas emissions (fossil fuels plus land use sectors), if assumptions about peatland emissions are correct. Current international negotiations on incentive systems for reducing emissions from deforestation and forest degradation in developing countries (REDD) have yet to clarify the scope of the intended rules and the relationship with other types of land use change emissions (previously deforested peatlands, agriculture and trees outside forest). However, the landscape-scale relationships between rural livelihoods, economic development and conservation and enhancement of above- and belowground carbon stocks need to be understood for any of the institutional mechanisms currently discussed.

Within Indonesia, the peatlands of Central Kalimantan are a recognized hotspot of emissions, with a complex history of planned and spontaneous land use change as their cause, within a peat dome environment that provides strong linkages between water tables and associated fire risk and requires the integration of management on a scale considerably above the village level. This report details a livelihood assessment that included an analysis of land management, poverty, gender, the role of fire and drainage practices for the area known as the 'Ex-Mega Rice Project' in Central Kalimantan, focussing on Block A (strongly affected by the Rice Project) and Block E (relatively intact) that cover parts of the major peat dome and adjacent rivers. This site was selected as a demonstration site for REDD under the Kalimantan Forest and Climate Partnership (KFCP) supported by the Governments of Australia and Indonesia.

\section{The study found:}

A. Livelihood strategies differed between the villages and between the blocks, alongside the condition of the remaining forest:

In the lower parts of Block A, the villages of Mentangai Hulu and Kalumpang were found to depend primarily on rubber and a rice/fallow rotation, with fishing and forest extraction of secondary importance. The importance of gold mining (in Mentangai Hulu) and extraction of rattan (in Kalumpang) differentiated the two villages in this zone.

In the Sei Ahas and Katunjung villages in the upper parts of Block A, agriculture (rubber and paddy) and forest extraction were of similar importance as a livelihood source. Logging of timber was the second most important source of livelihood in Sei Ahas village, while bark extraction of Alseodaphne coriacea (gemor) for mosquito repellent coils was the most important source of income in Katunjung village.

In block E, livelihoods primarily depended on fishing and forest extraction of gemor. Agriculture (rice as part of a swidden fallow system) and smallholder tree plantations were less important.

B. Dynamics of livelihood patterns could be understood in the light of policies in four periods of analysis: prior to 1970, before the Mega Rice Project (1970-1995), after the Mega Rice Project (1996-2006) and recent (2007-2008). The patterns alternated between six main 
activities: (i) rice cultivation (swiddening/fallow rotations), (ii) smallholder tree crop plantations (mostly rubber), (iii) forest timber extraction, (iv) collection of non-timber forest products, (v) fishing and (vi) other employment.

Prior to 1970, there was no commercial-scale logging in the area. Timber was used for local consumption and construction. Non-timber forest products such as rattan (Calamus spp.), damar (Shorea sp.), jelutung (Dyera costulata), eaglewood = gaharu (Aquilaria malaccensis), katiau (Ganua motleyana), kalanis (a tree root that gave rise to the toponym Tanjung Kalanis), ehang, nyatu (Palaquium javense) and animals (snake, bird and deer) were very important sources of livelihood. The swidden system with upland rice was practiced in both Block A and Block E. Fishing for local consumption was a very important source of livelihood. Smallholder tree crop plantations were not yet well developed.

Before the Mega Rice Project (1970-1996), commercial logging became an important determinant of local livelihoods. The timber concession companies (PT. Mangkatib Raya I, PT. Mangkatib Raya II, PT. Jayanti Jaya, PT. Sumber Alam and PT Sumber Usaha) operated in this region in the early 1970's, employing local people as laborers to log commercial timber species from the original mature high forests. Jobs linked to logging commercial timber became the most important source of local livelihood. Logging was supposedly selective and based on sustainable yield calculations, but in fact was more intensive than that.

During and after the Mega Rice Project (1997-2006): The Mega Rice Project was based on deep drainage, 'salvage logging', land clearing, transmigration of villages involving farmers from outside the area and irrigated rice. The few independent experts who had advised against the Project were correct; it provided economic benefits through logging and for the suppliers of the heavy equipment needed, but not for the rice farmers, many of whom started looking for other types of employment. After the 'reformasi', the Mega Rice Project was declared to be a "mega disaster" and efforts started to focus on rehabilitation of the area. After the Mega Rice Project, the relative importance of logging timber began to decline. Smallholder plantations (mostly rubber and rattan) and swidden-rice cultivation (rather than the permanent systems intended by the project) were very important in Block A, while in Block E, non timber forest product collection and fishing resumed their primary livelihood roles. Smallscale gold mining emerged as an important employment opportunity in Tumbang Muroi village in Block E.

Current Situation (since 2007): The current spatial pattern, described above, is related to the continued presence of forest in Block A with primary access from the river, and the transformed landscape in Block $\mathrm{E}$ with its transport pathways provided by the primary drainage canals. Fishing systems have adapted to the canals. Smallholder rubber plantations, stimulated by the high rubber prices after 2005 and adapted to peat soils, emerged as a livelihood component. Extraction of gemor continued in the forest, although the resources were locally depleted already; no domestication of the trees for cultivation closer to the villages has emerged as yet.

C. Various poverty indicators for the study area showed that the area was poor relative to the provincial baseline, while livelihood activities were differentiated by relative wealth and gender. Qualitative poverty indicators used locally included not only income, but also the level of education, health, employment opportunities and quality of housing. Dropout rates 
from schools for students aged 13-15 years were very high (24\%), indicating a problem in education at junior high school level.

The share of expenditure for primary food supplies in the study site was high (75-79\%) and above the provincial average. Protein consumption relative to carbohydrate was low. Using the national poverty line expenditure, $8.3 \%$ of the population was below the poverty line. The percentage of respondents living below the international poverty line of USD \$1 per capita per day was high (33-53\%, depending on the village).

The composition of income sources differed strongly between Block A and Block E. As described above, villagers in Block A were more dependent on agriculture (rubber), while villagers in Block E were very dependent on natural resources (forests and fish). Fishing provides income for everyone, especially for the poorer households. Income from fishing reduced the overall inequality of income distribution at both sites, as the concentration coefficients were less than one. Income from fishing was thus relatively high for the poorer segments of society, while about $97 \%$ of respondents engaged (part time) in fishing.

Forest extraction reduced the inequality of income in Block A but it increased the inequality of income in Block E. Since forest area was less available in Block A and accessing forest far away was costly, not many villagers in block A were interested in forest extraction work. However, forest remained an important resource for poor people who had limited access to other income sources. In contrast, the forest areas in Block E were more available and accessible. Gemor was an important source of income. About $35.5 \%$ of income in Block E came from gemor and about $57 \%$ of respondents engaged in gemor collection.

D. Gender differentiation in decision making. The involvement of women in production activities was quite prominent. For example, in every village, women influenced decisions on what type of plants were to be cultivated on agricultural land. However, there were differences in the level of involvement. The role of women in decision making was stronger in Block A than in Block E

The level of participation by women in livelihood activities varied. In some livelihood activities like fishing, rubber tapping, swidden-rice cultivation, rattan and kalanis root harvesting; women participated at a higher level than men.

The most specific role for women in household economic activities was found to be in marketing products. According to the respondents, women had a greater bargaining position in the transactions and had greater market knowledge than the men. Although, in general, women participated less in income-generating livelihood activities than men, they still contributed substantially to household income. This contribution was often hidden. Household income was often seen as income solely acquired by men, rather than as a joint effort, while the non-financial components remained hidden from the discussions held.

E. Profitability of swidden-rice cultivation, rubber and gemor. The swidden-rice cultivation was not profitable when opportunity cost of labour is calculated at going market prices. On the other hand, smallholder rubber plantation and gemor collection are profitable.

In the study area, the practice of swidden rice cultivation has declined over the years. However, swidden- rice cultivation is still considered to be important as part of the overall livelihood portfolio because of the importance of rice for food security, under uncertain 
income and price conditions. It was still attractive for some villagers since the return to family labor (income) was positive (IDR 24 038), although it was lower than the daily wage for agriculture (IDR 30 000.- per day). The swidden cultivation is very labor extensive, especially absorbing family labor, with less dependence on financial capital for external inputs. Labor cost accounted for $90 \%$ of total cost, the rest on expenditure for fertilizer and seed. Fertilizer and pesticide was applied to $25 \%$ of plots.

The total cost of rubber production in the first year was high as a cost for establishment, which consist for $61 \%$ of labor cost and $39 \%$ of external input cost. After the first year, investment is low during the immature period. Labor is needed for partial clearing to make tapping paths, and subsequently for tapping. Most trees, if not all, can be tapped before they reach the age of ten years, and gradually a net profit is derived, are investment was paid off. The time needed to positive cash flow depends on fluctuating rubber prices. At current prices, a net profit per hectare of IDR 3.3 million when wage rates were used for family labor inputs and total revenue of IDR 6.4 million per ha without accounting for the family labor inputs. Since rubber trees are established and managed primarily by family labor, the income from mature trees was high close to the total revenue. When total revenue is allocated to labout (at a net present value of zero for land), income or return to family labor for mature trees was IDR $65365 /$ day, which is higher than the wage rate for agriculture in this site.

Every villager was found to have free access to harvest gemor trees in the forest. No local ownership have yet emerged for gemor trees. Farmers usually go to the forest for a 7-14 day expedition to harvest the bark. Non-labor cost for such an expedition are around IDR 525 000/person for food, levy to enter tatah and gasoline for 13 person-days in the forest. In one trip a farmer could harvest $430 \mathrm{~kg}$ of gemor bark and transport it back to the village by boat ('kelotok'). The current price for dry gemor in the study site was IDR $4000 \mathrm{~kg}^{-1}$. The price for dry gemor in area close to Palangkalaraya was reported to be $6500 / \mathrm{kg}$ (Kompas, July 13,2009). The calculated return to labor was high (IDR 89 179/ day), three times the daily wage for agriculture (IDR $30000 /$ day), and $50 \%$ above the return to labor for smallholder rubber (IDR 65 365/ day)

F. Role of Fire. Fire in peat soils has frequently recurred in Block A area since 1997, when the peat areas were opened up for the Mega Rice Project Similar events occurred in 2005/2006 in Block E. In addition to economic loss, fires also caused smoke/haze that hampered village activities and affected people's health (particularly eye and respiratory problems, including breathing difficulties and coughing). Smoke/haze also affected transportation systems due to limited visibility that increased the risk of accidents.

In most villages, local fire regulations only involved sanctions if the fire had spread to neighbouring land. However, Desa Katunjung initiated Village Regulations (PERDES = Peraturan Desa), but these have not yet been implemented as they await approval at the Kabupaten level.

In some villages, such as Mantangai Hulu, Kalumpang, Sei Ahas, and Katunjung, fire teams (Regu Pemadam Kebakaran $=$ RPK) or community groups for fire management (Kelompok Masyarakat Pengendali Kebakaran $=\mathrm{KMPK}^{1}$ ) already exist. In these villages, people are

${ }^{1}$ RPKs (Regu Pemadam Kebakaran = Fire Extinguishing Team ) were formed in cooperation with the CARE
organization. Each RPK consisted of a team of $15-21$ people who had been trained in fire prevention and 
urged to inform the RPK, village head and local authorities when they planned to open up land using fire.

Villagers in Blocks $\mathrm{A}$ and $\mathrm{E}$ confirmed that there are regulations on using fire for land clearing. However, their understanding of the regulations varied. Some mentioned that the regulations prohibited the use of fire, while others said that the regulations included a procedure to obtain permission prior to land clearing. This lack of understanding showed that the land clearing regulations had not been successfully promulgated among village. In managing fire, farmers reported that they follow traditional rules/local laws inherited from their elders on sanctions/penalties when the fire spread to neighbouring land.

Farmers reported that they use 'slash and burn' techniques for land clearing for food as well as tree crops. They said they did not know a cheaper or more practical way to clear land for planting. They also felt that they did not need permission to do anything on their own land, except to inform their neighbours, so they could help in the activity and prevent the fire from spreading.

There were three main uses of fire by local farmers: to start a swidden, to clear for planting rubber and to create access for fishing activities. Slash and burn activity to open up land normally took place at the end of dry season, so the plot was ready for planting at the start of the rainy season. Fishing was also often carried out during the dry season, at baruh/lutu' and luwau by burning plants and bushes. These three activities potentially could cause escape of fires to surrounding vegetation.

G. Multiple functions of drainage canals. The community strongly felt that blockage of tatahs would result in the loss of their livelihood options to harvest non-timber forest products.

In the study areas, three types of man-made ditch were found that functioned as drainage systems: (i) canals, (ii) handil and (iii) tatah.

Canals were found in the Mega Rice Project at four levels (primary, secondary, tertiary, and quarternary). The canals were established to drain water from peat areas so that the land could be cultivated.

A Handil is a ditch that has been built voluntarily by locals as a drainage system in addition to providing transportation to support their agricultural activities (for annual crops as well as tree-based systems). Traditional use of handil as part as agricultural management was only found in the villlages of Block A that had been in existence since before 1970. According to the locals, the idea to established handil came when they could not find any more available land close to the river; all land had already been opened up and was owned by others. Consequently, farmers formed a group to establish handil so that they could open up land for cultivation that was far away from their settlement. Most handil were built from the end of $\mathrm{saka}^{2}$ together (Handap hapakat) with prior agreement on land allotment based on the number of people in a group.

management, including how to put out fires. Each team had one spray unit. KMPK (Kelompok Masyarakat Pengendali Kebakaran Hutan = Community Group for Forest Fire Management) had a similar function to the RPKs. KMPKs were formed by the government with 9-10 people in each team, with each KMPK having one spray unit.

${ }^{2} \mathrm{~A}$ saka is a river tributary with length less than $2.5 \mathrm{~km}$ 
A Tatah is a ditch that originally functioned to connect the river with forest areas, making it easy to access timber in the forests. Recently, with the dimunition of timber haresting in the forests, tatah were used to access non-timber forest products such as gemor, rattan and damar resin.

The community strongly felt that blockage of tatahs would result in the loss of their livelihood options to harvest non-timber forest products. Nevertheless, they could accept the construction of water gates and changes to make the tatah into small reservoir systems which the community could still use to access forest. Similarly, the community also opposed any program that planned to block any handil. According to locals, blockage of the handil would cause difficulties in accessing their agricultural land and their land would be flooded, resulting in reduced crop production.

\section{H. Opportunities and challenges for emission reduction}

Emission reduction strategies need to deal with the hydrological integrity of the peatdome and deal with drainage.

The deep drainage channels of the mega-rice program need to be closed as a first step (ongoing efforts), as its impacts can reach across the dome as a whole. The more superficial drainage of handil and tatah type canals probably does not extend beyond the village scale, but reducing their local impacts is still a priority for emission reduction. As these canals provide a transport function that is important for local livelihoods as well as drain the peat, water management systems for the canals that allow transport but reduce drainage are needed. Avoiding dry conditions in the canals actually is important for the transport function as well as the objective of reducing drainage, so some new solutions may be found.

A major challenge for effective emission reduction in the area is the need for an integrated approach across the peat dome, while the riparian edges of the dome are in the traditional sphere of influence of the villages and temporary settlements. Voluntary approaches to canal management are needed that recognize the opportunity costs for local livelihoods. Given the importance of fisheries in the local livelihoods, especially for the poorer households, interactions between canal management and fish production need to be considered. The levels of financial compensation needed to achieve canal management on an outcome-basis ("no new canals + modification of existing ones to reduce their drainage effects'), shall be a priority topic for REDD implementation in the area.

Beyond the drainage issue, landscape level management to control fires to reduce emissions also need attention, as the village institutions and scope for fire control are effective close by the village, but not further out in the landscape. Such efforts, beyond providing employment opportunities, will benefit the local livelihood systems as the smoke episodes are very unhealthy and may affect forest productivity (phenological data of the orang-utan research station suggest low levels of forest fruit production half a year after the last smoke/haze episode).

The initial ideas for the KFCP also include reforestation or tree planting in degraded peat area in block A, as third component beyond drainage reduction and fire control. The types of trees to be planted will need to take the livelihood strategies into account, as well the specific objectives of $\mathrm{C}$ storage. Tree $\mathrm{C}$ sequestration rates will be small relative to drainage and fire 
effects, so the interactions with those two processes can be important. Among the local tree resources, Gemor appears a logical candidate for planting and more intensive management. The study tree-based land use option will provide further analysis of this opportunity.

The livelihood data have revealed that a relatively large fraction of the population is poor and has few resources to invest and little opportunity to take risk. Villagers' response to initial canal blocking efforts have been negative and new options need to be discussed at local level and/or stimulated by outcome-based rules and incentives, rather than prescriptions of activities.

\section{Keywords}

Livelihoods, peatlands, gas emissions, Central Kalimantan, ex-mega rice project area, REDD 


\section{Acknowledgements}

This study is being conducted with the financial contribution of the Kalimantan Forests and Climate Partnership - Australia Indonesia Partnership as well as the World Agroforestry Center - The authors are solely for all the opinions in this document that does not necessarily reflect the Kalimantan Forests and Climate Partnership - Australia Indonesia Partnership and ICRAF. The authors would convey their gratitude to the enumerators; Laode Samsul Barani, Swandi and Martono who administered the survey and assisted with data management, also to the farmers of Mentangai Sub-District and Timpa Sub-District in Kapuas Regency, Kalimantan Timur. 


\section{Contents}

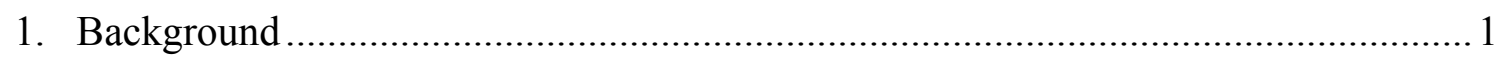

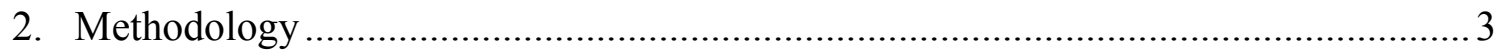

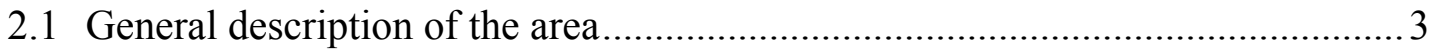

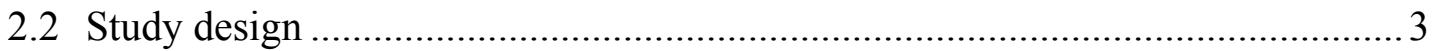

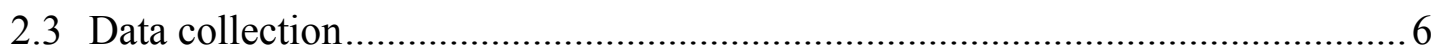

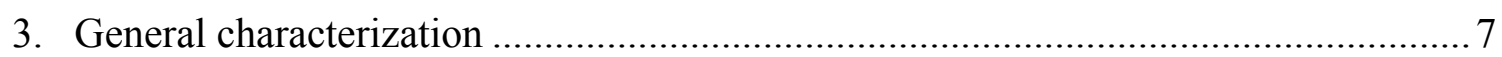

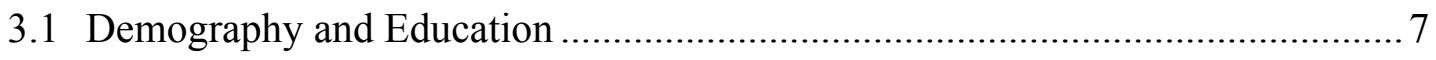

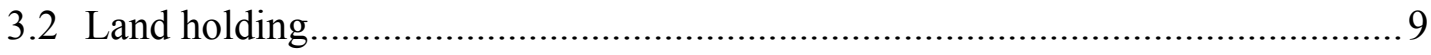

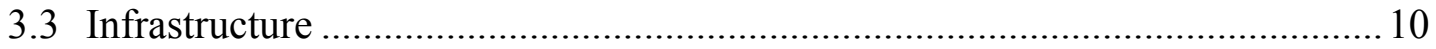

4. Livelihoods and peat management: from past to present....................................... 12

4.1 Community Peat Land Practices .................................................................... 12

4.2 Relative importance of components of the livelihood portfolio.........................22

4.3 Change in the relative importance of livelihood source over time..................... 24

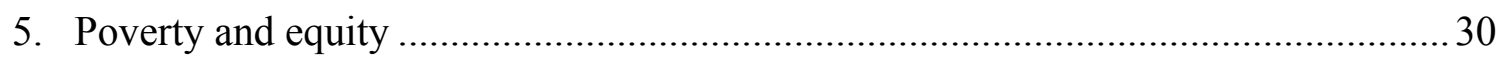

5.1 Poverty indicators: participatory assessment................................................... 30

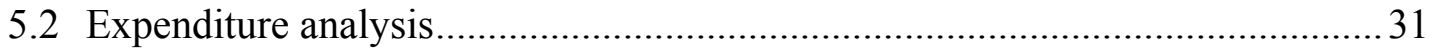

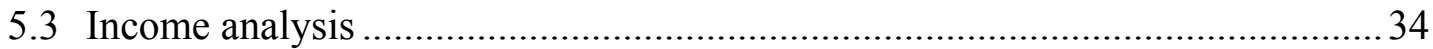

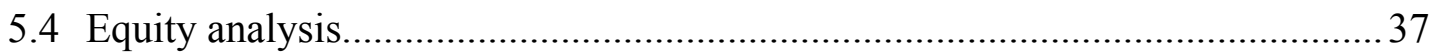

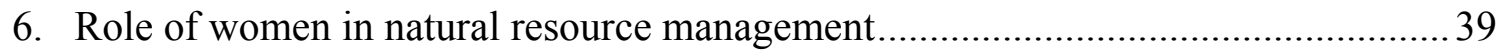

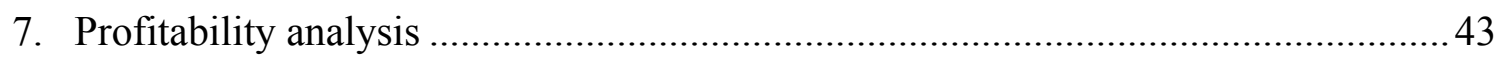

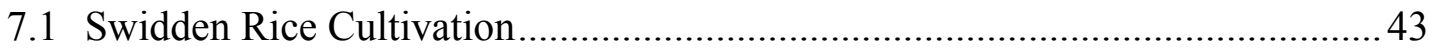

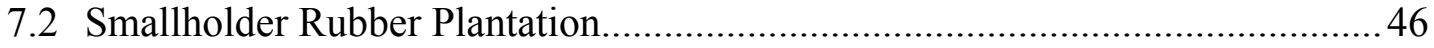

7.3 Opportunity Cost of Emission Reduction based on Profitability of Smallholder Rubber on Peat Land .............................................................. 48

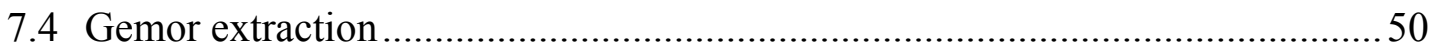

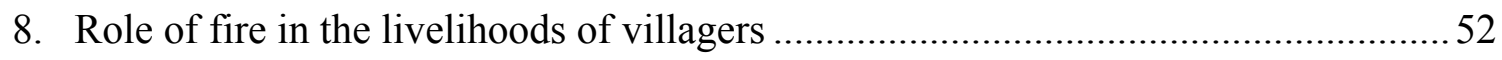

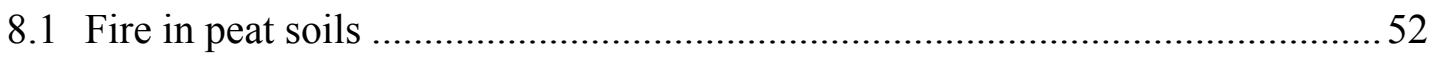

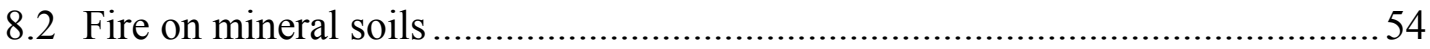

8.3 Regulations for the use of fire in land clearing activities .................................55

8.4 Local participation in preventing and tackling fires........................................56

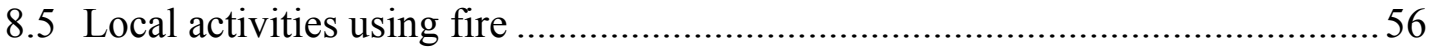




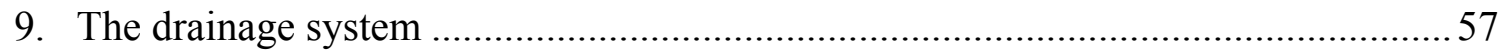

10. Opportunities and challenges for emission reduction ............................................6 60

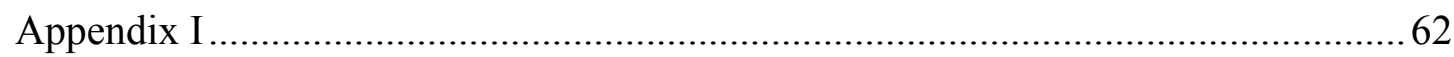

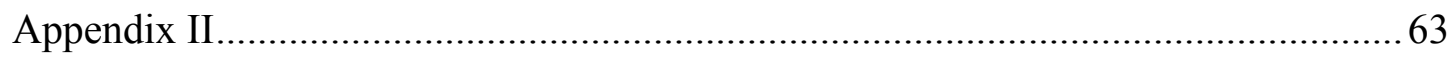

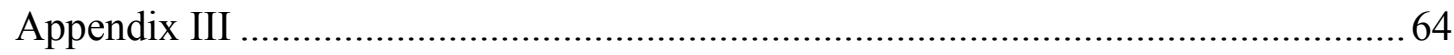

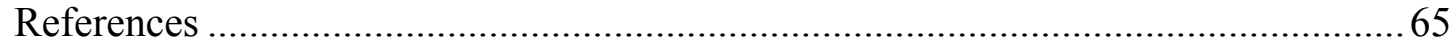




\section{List of Figures}

\begin{tabular}{|c|c|}
\hline Figure 1 & Location of study area in Central Kalimantan \\
\hline Figure 2 & Drying of Gemor \\
\hline Figure 3 & Qualitative trends in fish production over different periods in Block A \\
\hline Figure 4 & Qualitative trends in fish production over different periods in Block $\mathrm{E}$ \\
\hline Figure 5 & Floating Gold Mining in Kapuas River \\
\hline Figure 6 & Top five components of livelihood strategies In Block A villages \\
\hline Figure 7 & Top five components of livelihood strategies In Block E villages \\
\hline Figure 8 & Importance ranking of livelihoods in Mantangai Hulu Block A \\
\hline Figure 9 & Importance ranking of livelihoods in in Kalumpang Block A \\
\hline Figure 10 & Importance ranking of livelihoods in in Sei Ahas Block A \\
\hline Figure 11 & Importance ranking of livelihoods in Katunjung Block A \\
\hline Figure 12 & Importance ranking of livelihoods in Tanjung Kalanis Block E \\
\hline Figure 13 & Importance ranking of livelihoods in Tumbang Muroi Block E \\
\hline Figure 14 & Importance ranking of livelihoods in Kanjarau Block E \\
\hline Figure 15 & Importance ranking of livelihoods in Petak Puti Block E \\
\hline Figure 16 & Household expenditure by commodity group (\%) \\
\hline Figure 17 & Household income by activity type (\%) \\
\hline Figure 18 & $\begin{array}{l}\text { Participation by women in livelihood options of villages in Block } A \text {. } \\
\text { (Y axis refers to ranking) }\end{array}$ \\
\hline Figure 19 & $\begin{array}{l}\text { Participation by women in livelihood options of villages in Block E. } \\
Y \text { axis refers to ranking }\end{array}$ \\
\hline
\end{tabular}




\section{List of Tables}

\begin{tabular}{|c|c|}
\hline Table 1 & $\begin{array}{l}\text { Village/hamlet population and number of households in the study area } \\
2008 / 2009 \text { (village arranged in a south-to-north gradient) }\end{array}$ \\
\hline Table 2 & Population distribution by ethnic identity in the study area \\
\hline Table 3 & Population distribution by education level in the study area \\
\hline Table 4 & Average land holding by land use in study site \\
\hline Table 5 & $\begin{array}{l}\text { Availability of eduaction, health, road and market facilities in the study } \\
\text { area }\end{array}$ \\
\hline Table 6 & $\begin{array}{l}\text { Constraint faced in the management of paddy-swidden rice } \\
\text { cultivation over time }\end{array}$ \\
\hline Table 7 & Constraint faced in the management of smallholder plantations \\
\hline Table 8 & $\begin{array}{l}\text { Main forest products used by the residents in the villages in } \\
\text { Blocks } A \text { and } E\end{array}$ \\
\hline Table 9 & $\begin{array}{l}\text { Qualitative estimation of forest area reduction relative to the forest within } \\
\text { the village domain in } 1970 \text { and main causes mentioned }\end{array}$ \\
\hline Table 10 & $\begin{array}{l}\text { Description of livelihood options for migrating resident in } \\
\text { Blok A villages }\end{array}$ \\
\hline Table 11 & $\begin{array}{l}\text { Description of livelihood options for migrating resident in } \\
\text { Blok E villages }\end{array}$ \\
\hline Table 12 & Poverty indicators in education \\
\hline Table 13 & Number of households receiving BLT and Raskin in 2008 \\
\hline Table 14 & Monthly average expenditure per capita (IDR) by commodity group \\
\hline Table 15 & $\begin{array}{l}\text { Poverty line data and number of people below poverty line for regions in } \\
\text { Indonesia }\end{array}$ \\
\hline Table 16 & Sources of income in Block A and Block E in 2008 \\
\hline Table 17 & Income inequality in Block A and Block E in 2008 \\
\hline Table 18 & $\begin{array}{l}\text { Participation by women in deciding type of plants to cultivate in } \\
\text { Block A villages }\end{array}$ \\
\hline Table 19 & $\begin{array}{l}\text { Participation by women in deciding type of plants to cultivate in } \\
\text { Block E villages }\end{array}$ \\
\hline Table 20 & Participation by women in various livelihood options in Block A \\
\hline Table 21 & Participation by women in various livelihood options in Block E \\
\hline Table 22 & Participation by women in sale products in villages of Block $A$ \\
\hline Table 23 & Participation by women in sale products in villages of Block $\mathrm{E}$ \\
\hline Table 24 & $\begin{array}{l}\text { Gross revenue, production cost, residual profit and income of swidden-rice } \\
\text { cultivation }\end{array}$ \\
\hline Table 25 & Labor use per ha for paddy shifting cultivation by activities and gender \\
\hline Table 26 & $\begin{array}{l}\text { Labor used per hectare of smallholder rubber by activities and age of trees } \\
\text { in study site }\end{array}$ \\
\hline Table 27 & $\begin{array}{l}\text { Gross revenue, production cost, profit and income of smallholder rubber in } \\
\text { study site }\end{array}$ \\
\hline Table 28 & Regression of profit function of smallholder rubber in KFCP site \\
\hline Table 29 & Opportunity cost of smallholder rubber in 2009 \\
\hline Table 30 & Real carbon prices \\
\hline
\end{tabular}




\begin{tabular}{|l|l|}
\hline Table 31 & Revenue, cost and return to labor of gemor collection \\
\hline Table 32 & Large scale fire events in peat soils of Block A \\
\hline Table 33 & Large scale fire events in peat soils of Block E \\
\hline Table 34 & Fire events in mineral soils of Block A \\
\hline Table 35 & Fire events in mineral soils of Block E \\
\hline Table 36 & Type and number of drainage systems in villages of Block A \\
\hline Table 37 & Type and number of drainage systems in villages of Block E \\
\hline
\end{tabular}

-xiii- 
List of Appendixes

\begin{tabular}{l|l} 
Appendix 1 & The Gini index calculation
\end{tabular}

Appendix 2 Sketch map of Kalumpang village in Block A

\begin{tabular}{l|l} 
Appendix 3 & Sketch map of Tumbang Muroi village in Block E
\end{tabular}

-xiv- 


\section{Background}

Indonesia is now known as a country with very high carbondioxide and other greenhouse gas emissions from land use and land cover change, ranking third in overall emissions and with per capita emissions in between the levels of North America and Europe. A two-year window of enhanced learning on Reducing Emissions from Deforestation and Degradation (REDD) was agreed to in the Bali Roadmap of December 2007. This is expected to lead to international agreements on a comprehensive post-2012 implementation regime for the UNFCCC targets of emission reductions that will include the land use sector in non-Annex I countries. Indonesia is a prime target for international REDD efforts, although a substantial part of the emissions from peatlands will require a broader interpretation of the term 'forest' than is used in the current internationally accepted definition. The high level of emissions and large diversity of islands, situations and stakeholders provide specific challenges. Emissions in Indonesia are at least partly due to overlapping regulations and weak law enforcement, requiring a strengthening of feedback systems between the center and the regions through government and civil society. In part, past emissions have been due to 'planned' change, while part is considered 'illegal' or 'unplanned', and the distinctions between these categories are not easy due to interactions. A focus on areas with high emission baselines may be 'efficient', but stakeholders who are committed to long-term forest protection may not perceive this as 'fair'. Fair, efficient and sustainable emission reduction in Indonesia will require support for tree-based livelihoods that minimizes tradeoffs between rural livelihoods and the preservation of carbon (C) stocks. Institutionally, this will require transparent carbon accounting and negotiation support for local communities, NGO's and government agencies.

The Kalimantan Forests and Climate Partnership (KFCP) is a new initiative in the form of pilot projects to establish and demonstrate effective ways of reducing emissions from peatlands through the emerging REDD and associated schemes ${ }^{3}$. The goal of KFCP is “ ... to demonstrate a credible, equitable, and effective approach to reducing greenhouse gas emissions from deforestation and forest degradation, including from the degradation of peatlands that can inform a post-2012 global climate change agreement and enable Indonesia's meaningful participation in future international carbon markets."

The Australian Government has provided major investment (AUS \$30 million) to underpin the operation of the scheme, but further investments are likely needed. While the international rules on REDD are not yet clear and emissions from peatland may or may not be covered, there is widespread consensus that this type of emission reduction is feasible, urgent (high emissions) and probably cost effective. As the emissions from peatlands come from a relatively small area with a small local population, the social aspects may be manageable. However, they are not trivial and deserve full attention.

For the purpose of future monitoring and impact assessment, the project needs to conduct a baseline survey including the socioeconomic aspects. This report is complementary to the socioeconomic baseline survey that was conducted by CARE in all villages of the KFCP

\footnotetext{
${ }^{3}$ At the international level a range of options is still discussed: RED, REDD, REDD+, REDD++...
} 
target area. The ICRAF survey provided further depth on the livelihood assessment, land management practices, poverty, gender, role of fire and drainage in selected villages that are considered representative of the range of conditions in the target area. Beyond providing a baseline for future monitoring and evaluation, the study also provided insights into how fire and drainage, the two primary threats to peatland $\mathrm{C}$ stocks, are currently interacting with livelihood strategies in the area. These insights can be used to fine tune the design of interventions targeting emission reduction. 


\section{Methodology}

\subsection{General description of the area}

The KFCP target area consists of peat domes, rivers and riparian zones with sedimentation zones that enrich the natural vegetation with nutrients. The rivers provide the primary access for people, who use the river banks as places for temporary settlement and the surrounding area for a swidden (shifting cultivation) system. Throughout history, the people in the area have associated with the river rather than the land and moved upstream or downstream in response to security threats and trading opportunities. Along with the advance of more permanent public services (health care and schooling) and administrative/governance systems, the villages became permanent centers of habitation. Extended family networks and ethnic identity, however, continued to refer to larger areas that are constantly scanned for economic opportunities. With the rise and fall of legal and illegal logging operations, employment opportunities continue to shift. Further description of how the land use rights and tenure systems interact with land use is provided in a companion report.

With the construction of roads and drainage canals, transport and associated economic opportunities have provided a re-orientation of the landscape in the past two decades, although the river is still the major transport route connecting to the roads and to the capital and ports. This is partly due to the low suitability of land outside the riparian mineral soils for permananet structures such as roads or buildings. The spatial pattern thus contratsts with areas where new access roads have created development axes away from the river. The large drainage canal that was cur across the peat dome, forming the boundary od 'Block A' and 'Block E' has effectively opened up the peat dome.

Land use intensification has generally progressed from more accessible peat sites to more remote ones and from downstream (south) to upstream (north) in this peat land ecosystem. The Block A site was settled and logged out much earlier than the Block E site. The Block A site has been subjected to substantial development activities, which have included the Mega Rice Project and oil palm plantations. The Block E site is still largely under forest vegetation closely allied to the conservation of the orangutan.

\subsection{Study design}

This livelihood study was designed planned in parallel with studies of the tenure system, the institutional development around REDD and options for treebased livelihood improvement (see companion reports). It was designed as part of the socioeconomic baseline study that was carried out by CARE (see separate report). The study sites in Block A (south) and Block E (north) in the ex Mega Rice Project area, Kapuas District, Central Kalimantan were chosen to represent degraded forest and forested areas (Figure 1, Appendix 2 and 3). The area represents a demonstration site for REDD under the Kalimantan Forest and Climate Partnership supported by the Australian Government. Administratively, these villages belong to two sub- 
districts (Kecamatan) of the District (Kabupaten) Kapuas: Kecamatan Mantangai and Kecamatan Timpa. Overall, there are 14 settlements along the Kapuas River.

For the in-depth study, eight settlements were selected, involving six villages and two hamlets. Block A contained Desa Mantangai Hulu, Desa Kalumpang, Desa Sei Ahas and Desa Katunjung. Block E contained Desa Tumbang Muroi, and Dusun Tanjung Kalanis (Kecamatan Mantangai); Desa Petak Puti and Dusun Kanjarau (Kecamatan Timpa). Sample villages were purposefully selected based on size of settlement area. Consequently, villages rather than hamlets were selected in order to sample a larger population spread over a greater area. 


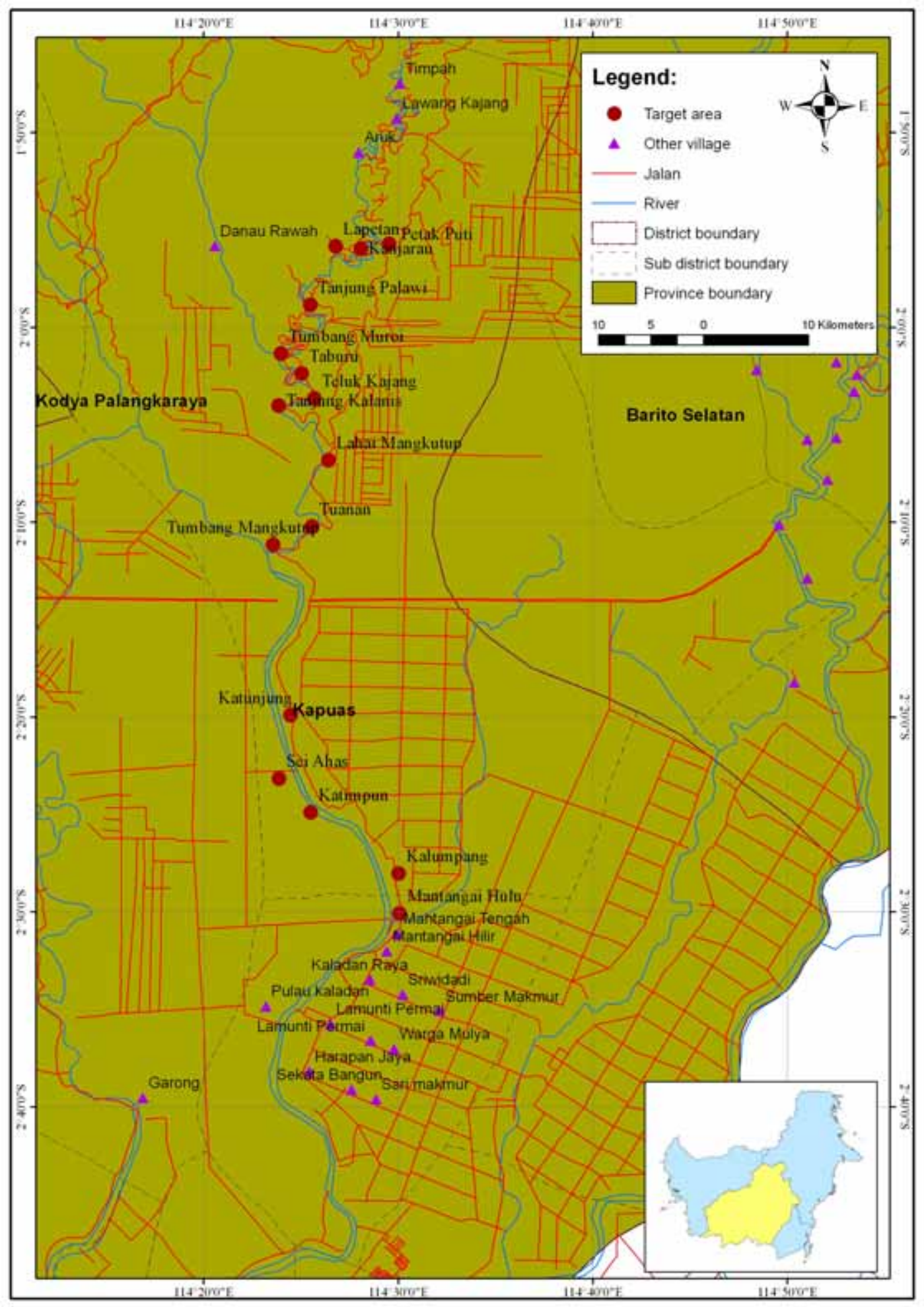

Figure 1. Location of study area in Central Kalimantan. 


\subsection{Data collection}

Focus group discussions were used to gather information on sources of livelihood, land management practices, demography, poverty, the role of gender, land tenure, major development or commercial activities, the condition of ecological resources, fire patterns and the drainage system. Focus groups discussions were conducted in four settlements/villages in each block. Around eight people representing the formal and informal leaders were invited to attend two days of discussion from 8 am to $5 \mathrm{pm}$.

Following up on issues raised at the focus group discussions, more quantitative data were collected through a survey at household level. A total of 30 respondents for each block ( 60 for the whole study) was randomly selected from the larger sample (1 000 respondents) used for the socioeconomic baseline survey carried out by CARE.

The questionnaires were written in Bahasa Indonesia in order to ease the process of data collection and improve communication between enumerators and respondents; team members from the University of Palangkaraya spoke the local language and provided translation where needed. As much as possible, both the husband and wife in each household were interviewed together, when data was being sought on family characteristics, such as: the number of family members; age and schooling of the household head; modes and years of land acquisition; land use before acquisition and at present; plot size for all crops; costs, family labor use, and revenue of land use types, such as rubber and swidden rice cultivation. Income and expenditure data for each household were used to assess the poverty level of respondents. 


\section{General characterization}

\subsection{Demography and Education}

Among the villages surveyed, Desa Mantangai Hulu was the most populous village (510 households, 1952 individuals). There were three other villages with a population of more than 1000: Kalumpang, Katunjung, and Tumbang Muroi (Table 1).

Table 1. Village/hamlet population and number of households in the study area 2008/2009 (village arranged in a south-to-north gradient)

\begin{tabular}{|l|c|c|c|c|}
\hline Village/hamlet & $\begin{array}{c}\text { Number of } \\
\text { households }\end{array}$ & Men & Women & Total \\
\hline Mantangai Hulu & 510 & 1,015 & 937 & 1,952 \\
\hline Kalumpang & 291 & 551 & 503 & 1,054 \\
\hline Sei Ahas & 231 & 440 & 436 & 876 \\
\hline Katunjung & 595 & 688 & 630 & 1,218 \\
\hline Tanjung Kalanis & 110 & 223 & 213 & 436 \\
\hline Tumbang Muroi & 414 & 884 & 862 & 1,746 \\
\hline Kanjarau & 112 & 192 & 161 & 353 \\
\hline Petak Puti & 238 & 394 & 414 & 808 \\
\hline
\end{tabular}

Source: Monograph and village profiles 2008 and 2009

There were three main ethnic groups living in the study area: Dayak, Banjar, and Javanese (Table 2). Other ethnic groups, such as Flores and Toraja, were identified in villages with smaller populations; most had intermarried with Dayak. All dayak refer to themselves as Dajak Ngaju, the group on the Kapuas and Kahayan river; no subdivisions were reported and all see groups upstream as well as downstream as close akin. 
Table 2. Population distribution by ethnic identity in the study area.

\begin{tabular}{|c|c|c|c|c|}
\hline \multirow[t]{2}{*}{ Village/Hamlet } & \multicolumn{4}{|c|}{ Ethnic Group (\%) } \\
\hline & Dayak & Banjar & Java & Others \\
\hline Mantangai Hulu & 98.3 & 1.6 & 1.0 & 0.2 \\
\hline Kalumpang & 95.0 & 3.0 & 2.0 & 0.0 \\
\hline Sei Ahas & 95.3 & 2.6 & 2.7 & 0.0 \\
\hline Katunjung & 95.5 & 2.5 & 1.0 & 1.0 \\
\hline Tanjung Kalanis & 98.0 & 0.0 & 2.0 & 0.0 \\
\hline Tumbang Muroi & 100.0 & 0.0 & 0.0 & 0.0 \\
\hline Kanjarau & 94.4 & 2.8 & 2.8 & 0.0 \\
\hline Petak Puti & 95.0 & 2.0 & 3.0 & 0.0 \\
\hline
\end{tabular}

Source: Estimation by village leaders

The people who identify themselves as Javanese are spontaneous migrants, arriving at different time periods and integrated through intermarriage. The study villages have contact with the transmigration villages, but little intermarriage has occurred so far. The Banjar people are the main traders of the area, and relate to Banjar Masin (the capital of S. Kalimantan) as their centre of economic connections (rather than Palangkaraya, the capital of C. Kalimantan).

Less than $50 \%$ of the population in each village had an education lasting more than six years (in order to reach the higher levels of education of secondary school, high school or university), except for Desa Kalumpang where $60 \%$ of the population had an education lasting more than six years. Table 3 summarizes the levels of education in the study area. 
Table 3. Distribution of population by education level in the study area.

\begin{tabular}{|c|c|c|c|c|}
\hline \multirow[t]{2}{*}{ Village/Hamlet } & \multicolumn{4}{|c|}{ Education level (\%) } \\
\hline & $\begin{array}{c}\text { Primary } \\
\text { school/non- } \\
\text { educated }\end{array}$ & $\begin{array}{l}\text { Secondary } \\
\text { School }\end{array}$ & $\begin{array}{r}\text { High } \\
\text { School }\end{array}$ & University \\
\hline Mantangai Hulu & 63.4 & 25.0 & 10.0 & 1.6 \\
\hline Kalumpang & 40.0 & 30.0 & 28.1 & 1.9 \\
\hline Sei Ahas & 75.0 & 15.0 & 10.0 & 0.0 \\
\hline Katunjung & n.a & n.a & n.a & n.a \\
\hline Tanjung Kalanis & 90.0 & 7.0 & 3.0 & 0.0 \\
\hline Tumbang Muroi & 85.0 & 10.0 & 4.7 & 0.3 \\
\hline Kanjarau & 93.6 & 5.6 & 0.8 & 0.0 \\
\hline Petak Puti & 75.0 & 15.0 & 9.0 & 1.0 \\
\hline
\end{tabular}

n.a $=$ not available

Source: Estimation by village leaders

\subsection{Land holding}

Based on our survey of 60 households and within the local concept of land tenure (see companion report), the average land holding of Block A villagers was larger (10.73 ha) than that of Block E villagers (4.14 ha). Villagers in Block A were more dependent on agriculture land especially on rubber plantation. The average rubber plantation land in Block $\mathrm{A}$ and $\mathrm{E}$ were 5.49 ha and 2.37 ha per household, respectively. This accounted for more than $50 \%$ from total land holding in both blocks; this does not include the fallow parts of the swidden cycle and other forest areas that the villagers consider as under their control. Currently cropped swiddens with rice in Block A were 0.7 ha/household, while in Block E it was almost none (0.03 ha). Bush fallow Rubber accounted for 3.9 ha/ household for Block A farmers and 2.2 ha/ household for Block E farmers (table 4). 
Table 4. Average land holding by land use in study site

Land Use

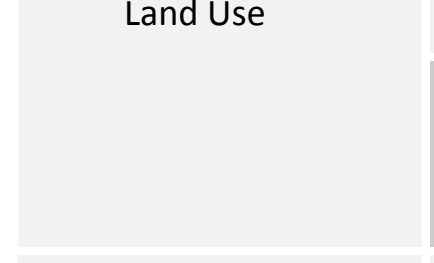

Swidden-rice

\begin{tabular}{|l|r|r|r|r|r|r|}
\hline cultivation & 0.7 & 0.86 & 0.1 & 0.03 & 0.7 & 0.45 \\
\hline Rubber plantation & 2.2 & 5.49 & 1.5 & 2.37 & 3.7 & 3.94 \\
\hline Rattan plantation & 0.2 & 0.48 & 0.1 & 0.25 & 0.3 & 0.36 \\
\hline Bush fallow & 1.5 & 3.90 & 0.7 & 1.49 & 2.2 & 2.69 \\
\hline Total & 4.6 & 10.73 & 2.4 & 4.14 & 6.9 & 7.44 \\
\hline Number of Respondent & 30 & & 30 & & 60 & \\
\hline
\end{tabular}

Block E

\begin{tabular}{c|c} 
Average & Average \\
Plot per & land \\
Househol & holding \\
d & $(\mathrm{Ha})$
\end{tabular}

Average
Plot per
Househol
d

Total

Average
land
holding
(Ha)

\section{Average} Plot per Househol d
Average land holding (Ha)

\subsection{Infrastructure}

School types within the study area could be divided into: kindergarten, primary school, secondary school, high school and Moslem school (madrasah) (Table 5). The availability of these schools provides the communities with the opportunity to receive an education at least until primary school level, because not every village had a secondary school or high school.

The health system in the area was relatively undeveloped. In some villages, health clinics were reported not to function well, as medical staff (a nurse or maternity nurse $=$ bidan) rarely stayed in the village, causing difficulties for sick villagers who need treatment.

Most villages are connected by paved (cemented) roads 1-1.5 m wide, except in Tanjung Kalanis, where the road still consists of bare earth and in Desa Mantangai Hulu, where the roads are made from sand and stone. Access to the markets in the villages was relatively good. There was a weekly market where villagers could obtain their daily needs, though not every village holds a weekly market. Villagers could go to the closest weekly market or wait for the merchant boat to stop by their village. The 'floating market' boats from Banjarese merchants pass by almost every day and offer a variety of goods. 
Table 5. Availability of education, health, road and market facilities in the study area.

\begin{tabular}{|c|c|c|c|c|c|c|c|c|}
\hline \multirow[t]{2}{*}{ Infrastructure } & \multicolumn{8}{|c|}{ Name of Villages } \\
\hline & $\begin{array}{l}\text { Mantang } \\
\text { ai Hulu }\end{array}$ & $\begin{array}{l}\text { Kalumpan } \\
\text { g }\end{array}$ & $\begin{array}{c}\text { Sei } \\
\text { Ahas }\end{array}$ & $\begin{array}{l}\text { Katunjun } \\
\mathrm{g}\end{array}$ & $\begin{array}{l}\text { Tanjun } \\
\text { g } \\
\text { Kalanis }\end{array}$ & $\begin{array}{l}\text { Tumbang } \\
\text { Muroi }\end{array}$ & Kanjarau & $\begin{array}{l}\text { Petak } \\
\text { Puti }\end{array}$ \\
\hline $\begin{array}{l}\text { Population } \\
\text { size }\end{array}$ & 1952 & 1054 & 876 & 1218 & 436 & 1746 & 353 & 808 \\
\hline $\begin{array}{l}\text { Education } \\
\text { Kindergarten } \\
\text { Primary } \\
\text { Secondary } \\
\text { High } \\
\text { Madrasah }\end{array}$ & $\begin{array}{l}1 \\
1 \\
0 \\
1 \\
0\end{array}$ & $\begin{array}{l}2 \\
1 \\
0 \\
0 \\
0\end{array}$ & $\begin{array}{l}0 \\
1 \\
0 \\
0 \\
0\end{array}$ & $\begin{array}{l}0 \\
1 \\
1 \\
0 \\
1\end{array}$ & $\begin{array}{l}0 \\
1 \\
0 \\
0 \\
0\end{array}$ & $\begin{array}{l}0 \\
1 \\
0 \\
0 \\
0\end{array}$ & $\begin{array}{l}0 \\
1 \\
0 \\
0 \\
0\end{array}$ & $\begin{array}{l}0 \\
1 \\
1 \\
0 \\
0\end{array}$ \\
\hline $\begin{array}{l}\text { Health } \\
\text { Puskemas } \\
\text { pembantu }\end{array}$ & 0 & 0 & 0 & 0 & 0 & 0 & 0 & 1 \\
\hline $\begin{array}{l}\text { Health clinic } \\
\text { Child center } \\
(\text { Posyandu) }\end{array}$ & $\begin{array}{l}1 \\
1\end{array}$ & $\begin{array}{l}1 \\
1\end{array}$ & $\begin{array}{l}1 \\
1\end{array}$ & $\begin{array}{l}1 \\
1\end{array}$ & $\begin{array}{l}0 \\
0\end{array}$ & $\begin{array}{l}1 \\
1\end{array}$ & $\begin{array}{l}0 \\
0\end{array}$ & $\begin{array}{l}0 \\
1\end{array}$ \\
\hline Nurse & 1 & 1 & 1 & 1 & 0 & 1 & 0 & 0 \\
\hline Doctors & 0 & 0 & 0 & 0 & 0 & 0 & 0 & 0 \\
\hline $\begin{array}{l}\text { Assistant } \\
\text { doctor }\end{array}$ & 0 & 0 & 0 & 0 & 0 & 0 & 0 & 1 \\
\hline Village road & $\begin{array}{l}\text { Stone and } \\
\text { Sand }\end{array}$ & Paved & Paved & Paved & Paved & Soil & Paved & Paved \\
\hline Market & None & Weekly & Weekly & None & None & None & $\begin{array}{c}\text { Occasiona } \\
\text { lly }\end{array}$ & $\begin{array}{c}\text { Week } \\
\text { ly }\end{array}$ \\
\hline $\begin{array}{l}\text { Nearest market } \\
\text { option }\end{array}$ & $\begin{array}{l}\text { Mantanga } \\
\text { i Tengah }\end{array}$ & & & Sei Ahas & $\begin{array}{l}\text { Floatir } \\
\text { me }\end{array}$ & $\begin{array}{l}\text { g market } \\
\text { chants }\end{array}$ & $\begin{array}{l}\text { Petak } \\
\text { Putih }\end{array}$ & \\
\hline
\end{tabular}

Source: Estimation by village leaders 


\section{Livelihoods and peat management: from past to present}

\subsection{Community Peat Land Practices}

\subsubsection{Swidden-Rice Cultivation}

Swiddening as a form of shifting cultivation is the oldest type of agriculture in Borneo. The Dayak "Ngaju" in Central Kalimantan have been practicing a swidden rice cultivation system for many generations (De Jong, 1994). The swidden fallow system or slash and burn practice is an agricultural cultivation system that is characterized by the use of fire to prepare fields for cultivation and the subsequent fallow of those fields as productivity declines due to the depletion of soil fertility. In the past, an average fallow period of 15 to 20 years was sufficient to restore soil fertility (Gouyon et al., 1993; Van Noordwijk et al., 2008). However, the average fallow period in the study area was now five years, which was much shorter.

Land clearing and land preparation occurred from July to October. There were four activities:

- Mahimbak (clearing the forest) or Mandirik (clearing the bush-fallow).

- Manalenteng (slashing and cutting the vegetation).

- Manusul (burning the biomass).

- Ma'akal (clearing the unburnt vegetation).

These activities were followed by seed planting from October to November. Local paddy varieties were usually used, such as: Garagai, Nampui, Manyahi, Lawa Kantur, Siam Kalanis, Pare Pudak and Kawung that could be harvested five to six months after planting. On average, 30 to $40 \mathrm{~kg} \mathrm{ha}^{-1}$ of seed was used. Planting activity is called Manugal in the local languange. Swidden-rice cultivation was very extensive, with the main crop care activity being weeding (Mambawau). Little or no fertilizer was used. Harvesting (Mangetam) occurred from March to April.

The number of constraints faced in swidden-rice cultivation has increased (Table 6). Prior to 1970, the constraints were only pests, lack of capital and lack of technology. Those constraints still remain. However, new constraints have arisen associated with environmental problems, such as flooding, fire, climate change, and declining soil fertility. The villagers found it difficult to predict the rainy and dry seasons, resulting in uncertainty on when to plant and when to avoid harvesting in the rainy season, which have resulted in the failure of rice crops in several recent years. Recently, government policy to ban the use fire for land clearing has reduced the practice of swidden rice cultivation in the study area. There are indications that the Mega Rice project has increased pest pressure for rice in the area, but this issue needs further exploration. 
Table 6. Constraints faced in the management of paddy-swidden rice cultivation over time.

\begin{tabular}{|l|l|}
\hline \multicolumn{1}{|c|}{ Time Period } & \multicolumn{1}{c|}{ Constraints } \\
\hline Prior 1970 & $\begin{array}{l}\text { Pest (pig, mouse, bird, monkey, brown plant hopper, green } \\
\text { leafhopper and rice), Capital, Technology }\end{array}$ \\
\hline $\begin{array}{l}\text { Before mega rice project } \\
\text { (1970-1995) }\end{array}$ & $\begin{array}{l}\text { Pest (pig, mouse, bird, monkey, brown plant hopper, green } \\
\text { leafhopper and rice bug), Capital, Technology, Manpower, Flooding }\end{array}$ \\
\hline $\begin{array}{l}\text { After mega rice project (1996- } \\
2006)\end{array}$ & $\begin{array}{l}\text { Pest (pig, mouse, bird, monkey, brown plant hopper, green } \\
\text { leafhopper and rice bug), Weeds (coarse grass), Fire, Climate change, }\end{array}$ \\
\hline Flooding
\end{tabular}

\subsubsection{Smallholder Tree Plantations}

The change from traditional swidden-rice cultivation to smallholder plantations began in the 1920s, when the Dutch colonial government and Chinese traders in the coastal cities introduced rubber as a commodity with global market demand (Dove, 1993). Since that time, farmers started planting rubber in their swiddens and/or in the fallow phase. Slash and burn was still practiced but rice was planted in the first or second year to pay for the cost of establishment. Since the 1960's, when the economic value of rattan was high, farmers started to cultivate rattan or mixed it in with the rubber agroforests, using native timber trees as support. Nearly all rubber planting material is derived from seed and refers back to the early introduction of rubber to the area. Only some farmers have started the use of grafting and clonal selections.

\subsubsection{Rubber}

Rubber was usually planted in mineral soils (tanah pematang), but recently farmers had also planted in peat soils on sites formerly in Mega Rice Project, where it can also grow well. There were two types of rubber garden in the study area: (i) mixed systems of rubber, rattan and other trees; and (ii) monoculture rubber.

\section{(i) Mixed Systems ('agroforests')}

Most of the mixed systems were in old rubber gardens that had not been established using any specific spacing of the plants. While more than $50 \%$ of the total tree basal area is rubber, tree diversity is high for the remainder of trees. All derive from the native forest vegetation and are selectively maintained from spontaneous establishment, rather than (trans)planted. Fruit trees found in the agroforest include: durian (Durio zibethinus), cempedak (Artocarpus champeden), mangga asam (Mangifera indica L.), rambutan (Nephelium lappaceum L.), kecapi (Sandoricum koecape), manggis (Garcinia hombroniana Pierre), duku (Lansium domesticum Corr), nangka (Artocarpus heterophyllus Lam), petai (Parkia sp.), rambai (Baccaurea angulata Merr), jambu (Psidium guajava L.), jeruk, ramunia, pinang (Areca catech $u$ L.) and asam kandis. The timber trees that could be found in the systems included: sengon (Paraserianthes falcataria; bamboo (bambu) (Dendrocalamus asper), mahang (Macaranga triloba), tumih (Combretocarpus rotundatus), tarantang (a timber tree with 
medicinal value and used by Orangutan as mosquito repellent - van Schaik, pers. Comm..), belangiran (Shorea belangiran), galam (Palaquium walsurifolium), tabuluh, marambung, kampua, kambasira, bungur (Lagerstroemia speciosa), kajak, rangas (Gluta wallichii), and bayur (Pterospermum javanicum. These trees were well maintained. As well as providing additional income, these trees could be used as poles for growing rattan.

\section{(ii) Monoculture rubber}

Monocultures of rubber plantations in the area had been recently planted and were not yet productive. Farmers used a monoculture to ensure improved growth of the rubber trees. Based on their experience, when rubber was mixed with rattan, the tapping started late (only after 10 years) and it was difficult to tap (because of the rattan). Therefore, they preferred to plant rubber as a monoculture. Farmers planted monoculture rubber at a spacing of $3 \times 3$ or $5 \times 5$ $\mathrm{m}$. The spacing depended on the capital available to buy seedlings, so that ideally, with enough capital, they would plant at a spacing of $3 \times 3$. Farmers preferred to use local rubber seedlings (Indonesian Rupiah [IDR] 500/seedling ) rather than clonal seedlings (IDR 5000/seedling).

Farmers did not tap their rubber trees continuously throughout the year. They reported to stop tapping when high tides inundated rubber gardens, usually from October to November and from March to April. Farmers expressed that rubber still is the most promising and reliable system available to them, reflected in the many newly planted rubber gardens found in Block A as well as in Block E. The period from September to October was the preferred time to plant rubber to ensure water availability and avoid droughts.

According to farmers, the yield per day of tapping latex depended on the climate and the condition of both the rubber trees and the rubber garden. Productivity of rubber decreased as the trees grew older. Good maintenance included weeding to make the rubber trees grow well and produce more latex. A long rainy season would reduce production as farmers would not tap during this season.

\subsubsection{Rattan}

Rattan was the second-most important commodity (after rubber) managed by farmers in the (forest) gardens. Planting rattan had been practiced by farmers prior to 1970. Rattan cultivation was boosted for two reasons: (i) good prices and (ii) local household needs (for fishing tools, storing rice and mats). Two main varieties of rattan were cultivated by farmers: irit rattan and sigit rattan. Both varieties were cultivated because they were not available from the forest around the village. Sigit rattan was considered to be of better quality than irit rattan. Irit rattan growth is, according to the farmers, similar to taro (cocoyam) growth, as its root continuously forms new shoot. Sigit rattan is reported to grow like bamboo, forming a substantial cluster of stems. Both varieties can be harvested after 10 years; the rattan will rejuvenate and form new shoots after harvest. The second generation rattan can be harvested after three to five years, although the best quality is harvested at five years of age. Rattan plants currently growing in gardens were planted before 1990. At the time of the study, farmers were no longer interested in managing their rattan gardens; they felt that rubber was more profitable and reliable. Maintaining rattan in a rubber garden was considered more tedious, particularly due to the weeding required. 
The number of constraints reported by smallholder plantations (rubber and rattan) had increased over the years (Table 7). The current major constraints were: flooding, fire, declining soil fertility, and pests. In addition, the lack of investment capital, low intensity of management and price uncertainty are also constraints.

Table 7. Constraints faced in the management of smallholder plantations.

\begin{tabular}{|l|l|}
\multicolumn{1}{c|}{ Time Period } & \multicolumn{1}{c}{ Constraints } \\
\hline Prior 1970 & $\begin{array}{l}\text { Seed, Capital, Pest (deer, pig, termites, monkey), Flooding, } \\
\text { Knowledge and technology }\end{array}$ \\
\hline $\begin{array}{l}\text { Before mega rice project } \\
\text { (1970-1995) }\end{array}$ & $\begin{array}{l}\text { Seed, Manpower, Pest (deer, wild boar), Knowledge and } \\
\text { technology }\end{array}$ \\
\hline $\begin{array}{l}\text { After mega rice project } \\
(1996-2006)\end{array}$ & $\begin{array}{l}\text { Capital, Fire, Flooding, Pest (termites, deer, wild boar), } \\
\text { Knowledge and technology, Weeds (coarse grass) }\end{array}$ \\
\hline $2007-2008$ & $\begin{array}{l}\text { Flooding, Fire, Pest (termites, deer, wild boar), Capital, Declining } \\
\text { of soil fertility, High cost of using pesticide and fertilizer, } \\
\text { Knowledge and technology, Weeds (coarse grass), Price } \\
\text { uncertainty }\end{array}$ \\
\hline
\end{tabular}

\subsubsection{Forest Extraction}

\subsubsection{Logging}

In the study area, the Dayak people perceived up to this day that forest are an open access resource, implying that anyone from their community along the river can access the forest without being restricted by any territorial ties. People from the study area currently look for gemor in areas upstream, for example, as more accessible supplies are depleted. As further detailed in the tenure report, the Dayak claim on forest access is not accepted by forestry authorities. Rules for forest access or management defined externally are not accepted by the Dayak villages. The Dayak people stated that the forest was occupied by a mystic spirit. To access and exploit the forest, the villagers needed to ask for the permission of the spirit (rather than obtaining government permits).

Table 8 shows the main forest products used by villagers sorted by ranking over time. Before the 1970s, people used timber for their own consumption, such as for housing and boat (Klotok) construction. In this period the non-timber forest products, such as getah jelutung (Dyera costulata), getah hangkang (Palaquium leiocarpum Bl.), getah nyatu (Palaquium javense), getah katiau (Ganua motleyana), dammar (Shorea sp.) and rattan were more important. Since the 1970s, timber commercialization commenced and reached a peak in the period 1990-1995. Local people called that period "Jaman Ramin" (the ramin era). Ramin (Gonystylus bancanus) was the most sought after species. Others valuable timbers were kayu ulin (Eusideroxylon zwageri), meranti (Shorea sp.), jelutung (Dyera costulata), belangiran (Shorea belangiran), kemedang (Litsea spp.), and kruing (Dipterocarpus sp.). The commercialization of timber was triggered by three factors:

(i) The entrance of timber concessions such as PT. Mangkatib Raya I, PT. Mangkatib Raya II, PT. Jayanti Jaya, PT. Sumber Alam and PT Sumber; 
(ii) Local investors from Banjarmasin recruiting villagers to log the timber.

(iii) The income from farming and fishing were lower than daily wage rates obtained from logging.

Since the Mega Rice Project in 1995, it became difficult to source valuable timber species. Thus, non-timber forest products, such as rattan and gemor (markets emerged in the 1970's, see below) became more dominant than timber. In recent years (2007-2008), logging of timber species such as meranti, kruing, benuas, and kemedang has occurred again, but it is of lower importance than the non-timber forest products.

The amount of forest area and forest products has each continued to decline because of several causes:

(i) Forest exploitation by timber concessions.

(ii) Illegal logging.

(iii) The Mega Rice Project.

(iv) Agricultural clearing by the local people.

(v) Conversion of forest area into palm oil plantation area (PT RASR based in Sei Ahas village).

(vi) Forest fires, which occur regularly during the dry season.

Table 8. Main forest products used by the residents in the villages in Blocks A and E.

\begin{tabular}{|c|c|c|c|}
\hline Prior 1970 & $\begin{array}{c}\text { Before Mega Rice } \\
\text { Project (1970-1995) }\end{array}$ & $\begin{array}{c}\text { After Mega Rice } \\
\text { Project (1996-2006) }\end{array}$ & 2007-2008 \\
\hline Getah jelutung & Ramin & Meranti & Gemor \\
\hline Getah hangkang & Meranti & Gemor & Rattan \\
\hline Getah Katiau & Jelutung & Rattan & Damar \\
\hline Hetah Nyatu & Ulin & Kemedang & Honey \\
\hline Rattan & Belangiran & Belangiran & Kalanis Root \\
\hline Damar & Kemedang & Kruing & Deer \\
\hline Ulin & Kruing & & Snake \\
\hline Meranti & Gemor & & Meranti \\
\hline Animals & Rattan & & Kruing \\
\hline Bird, etc) & Animals & & Benuas \\
\hline & Bird, etc) & & Kemedang \\
\hline
\end{tabular}

Note: sorted by ranking of importance 
Table 9. Qualitative estimation of forest area reduction relative to the forest within the village domain in 1970 and main causes mentioned

\begin{tabular}{|c|c|c|c|c|c|}
\hline \multirow[t]{2}{*}{ Village } & \multicolumn{4}{|c|}{ Qualitative estimation of forest area reduction (\%) } & \multirow[b]{2}{*}{ Remaining } \\
\hline & $\begin{array}{l}1970- \\
1995\end{array}$ & Causes & $\begin{array}{l}1996- \\
2009\end{array}$ & Causes & \\
\hline $\begin{array}{l}\text { Mantangai } \\
\text { Hulu }\end{array}$ & 10 & Illegal logging & 80 & $\begin{array}{l}\text { Mega Rice Project } \\
\text { and oil palm } \\
\text { plantation }\end{array}$ & 10 \\
\hline Kalumpang & 20 & $\begin{array}{l}\text { Illegal logging and } \\
\text { establishment }\end{array}$ & 80 & $\begin{array}{l}\text { Mega Rice Project } \\
\text { and oil palm } \\
\text { plantation }\end{array}$ & 0 \\
\hline Sei Ahas & 10 & Illegal logging & 70 & $\begin{array}{l}\text { Fire, Mega Rice } \\
\text { Project and oil } \\
\text { palm plantation }\end{array}$ & 20 \\
\hline Katunjung & 30 & $\begin{array}{l}\text { Illegal logging and } \\
\text { establishment }\end{array}$ & 60 & $\begin{array}{l}\text { Mega Rice Project } \\
\text { and Fire }\end{array}$ & 10 \\
\hline Tanjung Kalanis & 40 & $\begin{array}{l}\text { Forest concession } \\
\text { and Illegal logging }\end{array}$ & 10 & Fire & 50 \\
\hline $\begin{array}{l}\text { Tumbang } \\
\text { Muroi }\end{array}$ & 10 & Illegal logging & 20 & $\begin{array}{l}\text { Fire and } \\
\text { Establishment of } \\
\text { agriculture }\end{array}$ & 70 \\
\hline Kanjarau & 25 & $\begin{array}{l}\text { Fire and } \\
\text { Establishment of } \\
\text { agriculture }\end{array}$ & 25 & $\begin{array}{l}\text { Fire and } \\
\text { Establishment of } \\
\text { agriculture }\end{array}$ & 50 \\
\hline Petak Puti & 30 & $\begin{array}{l}\text { Fire and } \\
\text { Establishment of } \\
\text { agriculture }\end{array}$ & 10 & $\begin{array}{l}\text { Fire and } \\
\text { Establishment of } \\
\text { agriculture }\end{array}$ & 60 \\
\hline
\end{tabular}

Table 9 indicates that the reduction in forest area in the period 1970 - 1995 was due mostly to illegal logging, agricultural land clearing and logging activities by concession companies. In the period 1996 - 2009, the Mega Rice Project, forest fires, land clearing for agriculture, and establishment of oil palm were the main causes of a reduction in forest area. Continuous deforestation caused the forest to become more distant from the villages. The distance to the forest in Block A is farther than in Block E.

\subsubsection{Gemor (Alseodaphne coriacea)}

Farmers became aware of the value of the bark of gemor (Alseodaphne coriacea) in the 1970 's from traders from the Banjar, where the bark had an established commercial value. The bark of gemor plants can be used to effectively repel mosquitoes (Zulnely and Martono, 2003) The traders asked farmers to collect gemor bark, which the traders then purchased. Initially, not many farmers were involved in collecting gemor. However, now gemor collection has become important in many livelihoods, especially for villagers around Block E. 


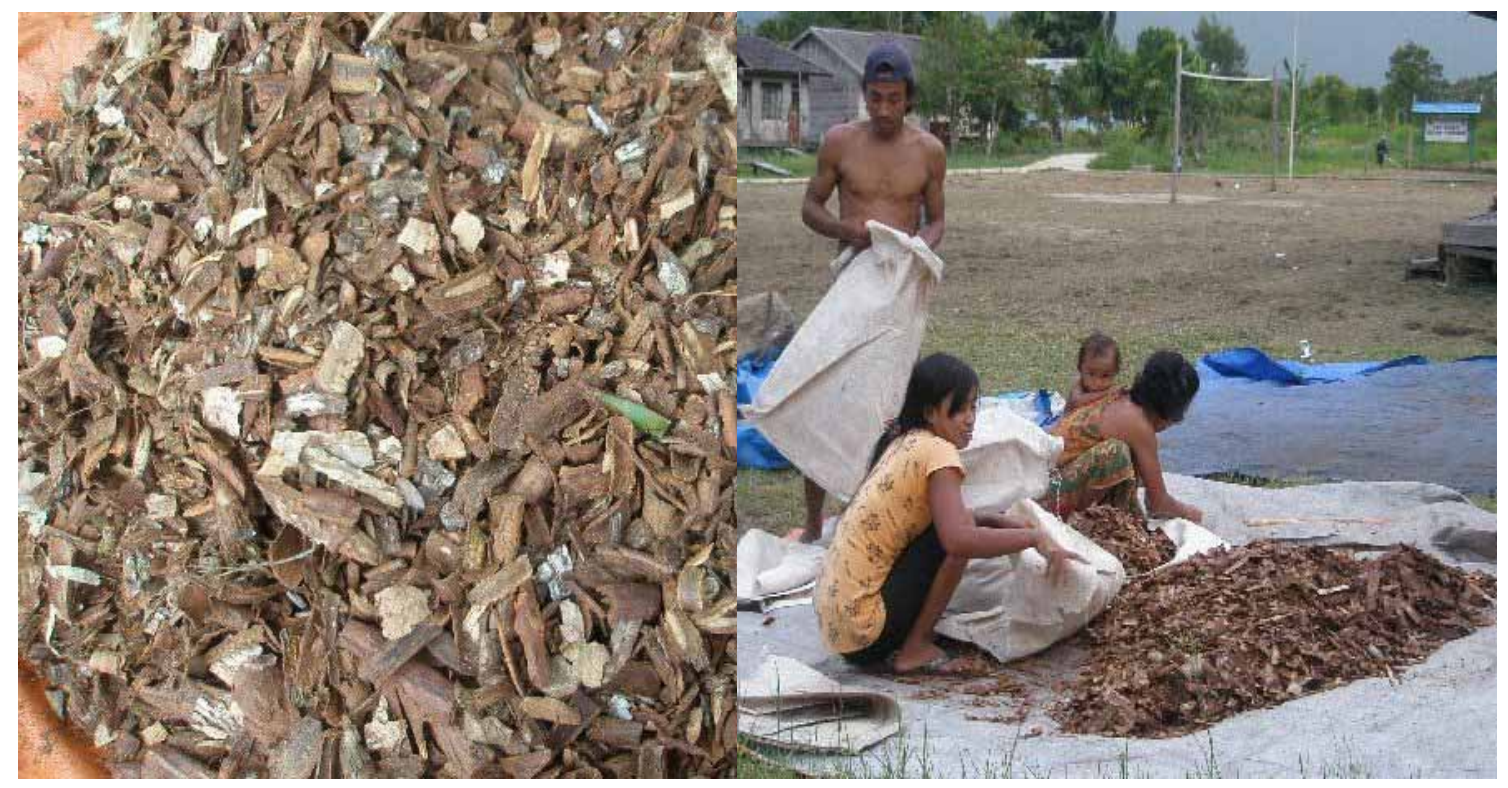

Figure 2. Drying of Gemor

The collection of gemor involved felling the big trees and removing the bark. Gemor bark could be sold fresh as well as dry. Dry bark fetched a higher price than fresh bark. In the past, only dry bark could be sold and it is only recently that both fresh and dry bark have been sold, probably reflecting resource depletion across the supply zone. In the past, big trees of gemor with a diameter of around $90 \mathrm{~cm}$ were available in the forest, producing around 5-7 quintal (1 quintal $=100 \mathrm{~kg}$ ) of dry bark. Now, gemor trees are limited to a diameter of around $5-15 \mathrm{~cm}$ that produces only around 10-20 kg of dry bark.

\subsubsection{Fishing}

Fishing provides a main source of income as well as local consumption. Initially, fishing was part of the daily life of most villagers but it has gained a more commercial purpose because of increasing law enforcement regarding illegal logging activities. Fishing thus became more important to villager livelihood as a source of cash income. This situation was supported by a better price for fish and an increase in the many traders who came to the villages to buy the catch.

Four types of fishing were identified in the study area.

\section{(i) Fishing in the river}

This commonly occurred in the Kapuas River or batang danum and in branches/upstream of the Kapuas river, such as in sungai Mantangai, sungai Ahas, sungai Muroi, sungai Kanjarau. In addition fishing also occurred further upstream in the Kapuas, and in the Saka, a very small stream with a total length of less than $2.5 \mathrm{~km}$.

The villagers catch fish throughout year. However, production in the rainy season was reported to be higher than in the dry season.

\section{(ii) Fishing in peat areas}

Several different locations provided fishing opportunities. 
Lakes (danau): The locals defined danau as a lowland area without vegetation and inundated with water throughout the year, especially during the rainy season. Usually, people caught fish in the lakes throughout the year.

Luwau : Luwau was described as an area of flood water that looked like a small lake with a diameter of less than $20 \mathrm{~m}$. A Luwau channeled to the river during the rainy season when the water table was high, so many fish could enter. However, during the dry season and the lowering of the water table, many fish became trapped and were easy to collect.

Baru/lutu: Baruh/lutu is a small pond that looks like a hole made after a large tree has been uprooted. During the rainy season when the rivers overflow, such holes are filled with water. During the dry season, farmers caught the trapped fish when the water table lowered.

Napu: Napu are ponds along the Kapuas river and become inundated with water during the rainy season when the river overflows. During the rainy season and at high tides, many fish congregated in the napu, so many people caught fish there.

Swamp forest: The swamp forest is inundated with water throughout most of the year. During the rainy season or at high tides, large numbers of fish can be found in this area.

\section{(iii) Fishing in canals}

A canal is an artificial channel filled with water. There are many canals in Block A that were established during the Mega Rice Project after 1996. Villagers caught fish in the canals, especially in the primary and secondary channels, throughout year.

\section{(iv) Beje}

There are two types of beje managed by the communities, namely beje natural (beje made from luwau or baruh) and artificial beje (a pond is dug out), which are owned privately. Beje are connected to the river, so during the rainy season when the water table rises, many fish enter the beje and are trapped when the water table lowers in the dry season.

There are more than 20 fish species caught, but some species such as baung (Mystus micracanthus), patin (Pangasius hypophthalmus), haruan (Ophiochepalus striatus), kakap (Lates calcalifer), toman (Channa micropeltes), and tapah (Wallago leeri) have high commercial value, so these fish are commonly sold by the villagers. Other species caught are generally only used for domestic consumption.

Figure 3 and 4 shows the qualitative trend in fish production over time. In general, fish production has declined over time in Block A and Block E; the yield of fish in the area has decreased over time. This is a reflection of the unsustainable way of fishing. Over-fishing due to large number of fishers and unselective fishing (no threshold on size) had slowly depleted the fish resources. In addition, the use of 'harmful' fishing practices, such as using poison (putas) and electricity had killed small (young) fish halting natural succession. A further factor was the impact of waste (mercury) from gold mining activities that have polluted the river. 


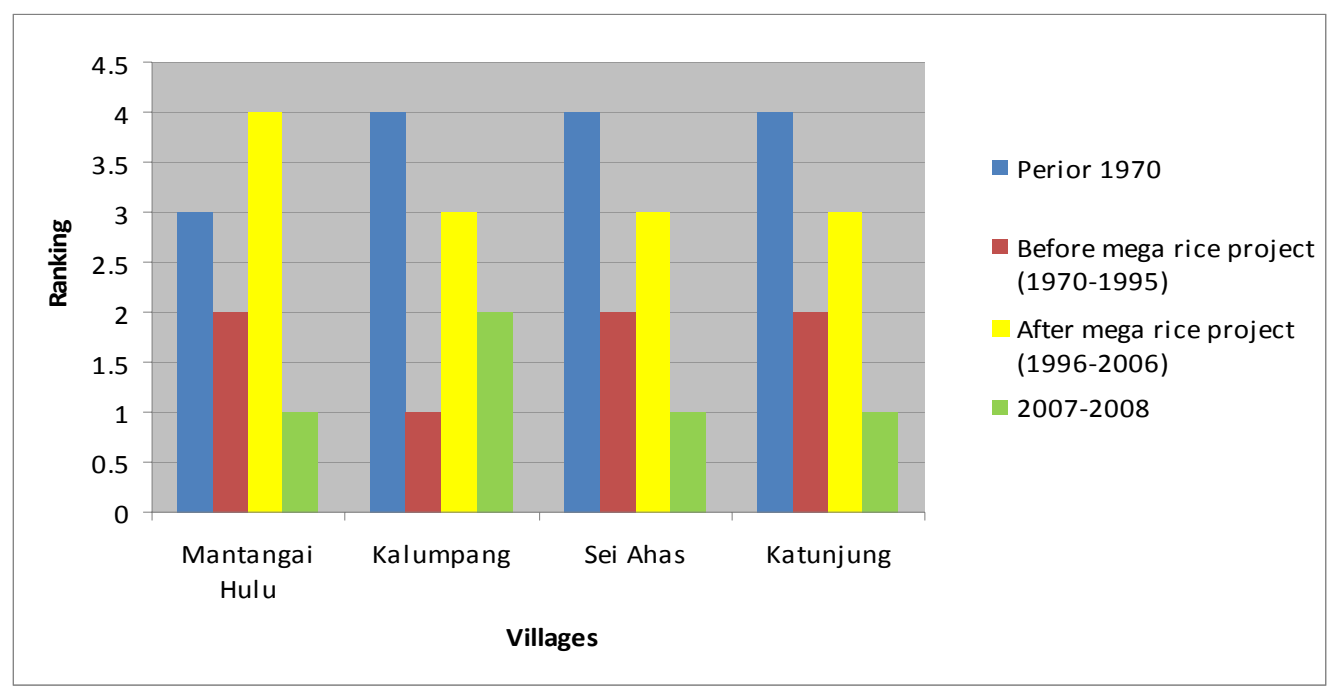

Figure 3. Qualitative trends in fish production over different periods in Block A

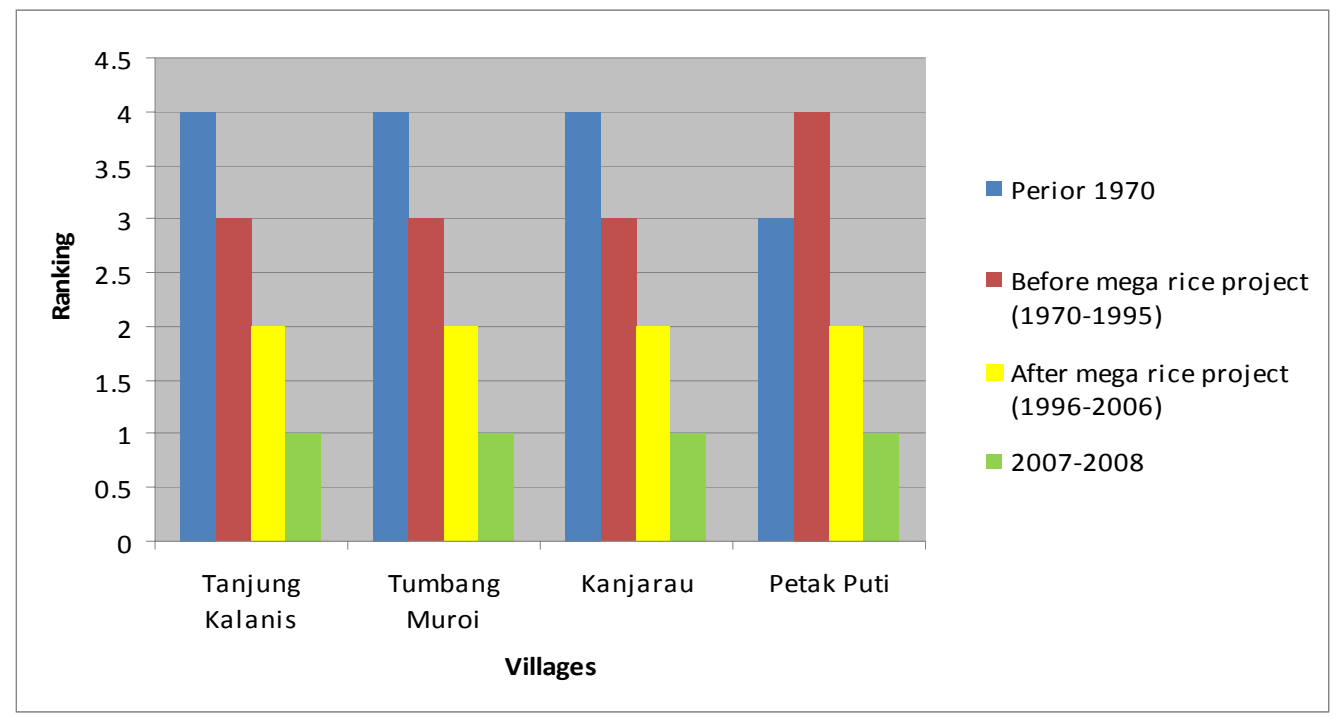

Figure 4. Qualitative trends in fish production over different periods in Block E

\subsubsection{Labor in Gold Mining}

Working in gold mining was also an important livelihood. People who worked in gold mining, migrated for a maximum of one year, mostly to Kecamatan(sub-districts) Mentangai and Kecamatan Timpa, two neighbouring sub-districts within Kabupaten (District) Kapuas. Gold miners normally sent home their money to their village while they were still working out of village (Tables 10 and 11).

Villagers started gold mining using spray machinery in the study area in the 1980's. The technique was adopted from similar activity in Palangkaraya. The current popular practice for gold mining along the river was to use suction machinery. Villagers were no longer attracted to gold mining inland using spray machinery. Most villagers became paid gold miners in a group. One group had a team of four laborers. The investors behind the gold mining activities 
by the villagers were gold traders from Balikpapan (the capital of East Kalimanta province). Gold miners sold their gold to these traders/investors. Farmers calculated the gold production based on the amount of fuel they used. They estimated that for 1 drum of fuel (approximately 200 1) they could get 8-9 gram of gold. The current price of gold was IDR 200000 per gram, while the price of fuel varied between IDR 600000 to IDR 1000000 per drum. Mercury was used in the gold mining process, polluting the Kapuas river. Intensive gold mining also caused bank collapses along the river, increasing turbidity and sedimentation in the river. The hazardous impact of gold mining to the environment and the health of the people was not fully understood by the villagers.

Table 10. Description of livelihood options for migrating residents in Block A villages.

\begin{tabular}{|c|c|c|c|}
\hline Village & Period out of village & Migrating location & $\begin{array}{c}\text { Amount of cash } \\
\text { dispatched IDR/month) }\end{array}$ \\
\hline Mantangai Hulu & 1-12 months & $\begin{array}{l}\text { Timpa, Kapuas } \\
\text { Tengah, Kapuas } \\
\text { Hulu }\end{array}$ & $200000-500000$ \\
\hline Kalumpang & 2 weeks -3 months & Muroi & $300000-500000$ \\
\hline Sei Ahas & $2-3$ months & Muroi & $200000-1000000$ \\
\hline Katunjung & $1-3$ months & $\begin{array}{l}\text { Muroi, Timpa, } \\
\text { Pujon (Barito) }\end{array}$ & $500000-1000000$ \\
\hline
\end{tabular}

Table 11. Description of livelihood options for migrating residents in Block E villages.

\begin{tabular}{|l|l|l|c|}
\hline \multicolumn{1}{|c|}{ Village } & $\begin{array}{c}\text { Period out of } \\
\text { village }\end{array}$ & Migrating location & $\begin{array}{c}\text { Amount of cash dispatched } \\
\text { (IDR/month) }\end{array}$ \\
\hline $\begin{array}{l}\text { Tanjung Kalanis } \\
\text { 2-6 months }\end{array}$ & Muroi & $300000-500000$ \\
\hline Kumbang Muroi & $1-2$ months & Village vicinity & $300000-1000000$ \\
\hline Kanjarau & $2-3$ months & $\begin{array}{l}\text { Timpa, Pujun, } \\
\text { Muroi }\end{array}$ & $500000-1000000$ \\
\hline Petak Puti & $1-3$ months & $\begin{array}{l}\text { Muroi, Pujun, } \\
\text { Timpa }\end{array}$ & $500000-700000$ \\
\hline
\end{tabular}

$I D R=$ Indonesian Rupiah 


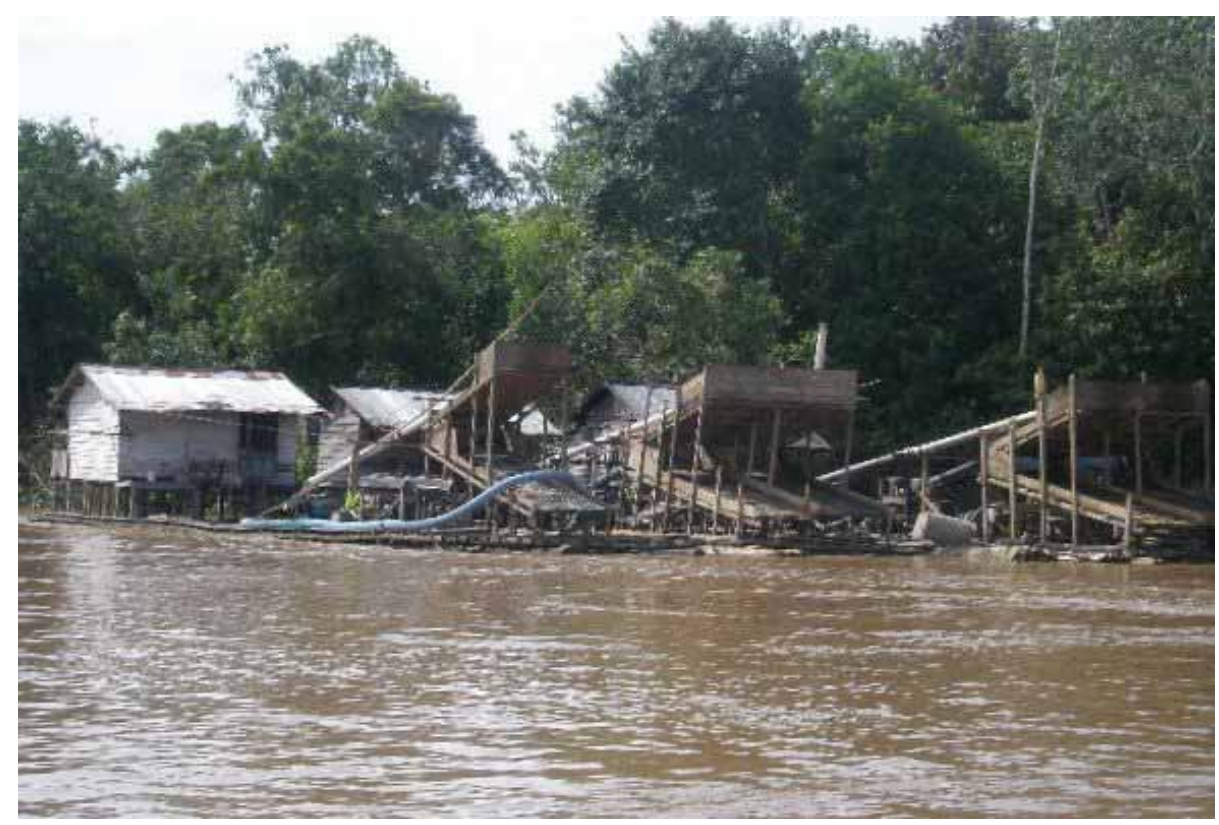

Figure 5. Floating Gold Mining in Kapuas river

\subsection{Relative importance of components of the livelihood portfolio}

A sample of villagers was used to qualitatively assess the relative importance of livelihood (top five values). There was a different pattern in the relative importance of livelihoods within the villages and between the blocks. In the villages of Mentangai Hulu and Katunjung (lower part of Block A), agriculture (rubber and swidden-rice cultivation) was more important than fishing and forest extraction. In Mentangai Hulu village, rubber was the most important source of livelihood followed by swidden-rice cultivation and fishing, with a small contribution from forest extraction and working in gold mining. Kalumpang village was similar to Mentangai Hulu, except that the extraction of rattan was important (ranked third).

In the middle of the lower part of the study area (Sei Ahas and Katunjung villages), both agriculture (rubber and paddy) and forest extraction were equally important sources of livelihood. Logging of timber was second most important in Sei Ahas village and gemor was the most important livelihood in Katunjung village. Rubber and rice were also important. In block E, contrary to the Block A results, the major livelihoods were fishing and forest extraction of gemor (Figures 6 and 7). 


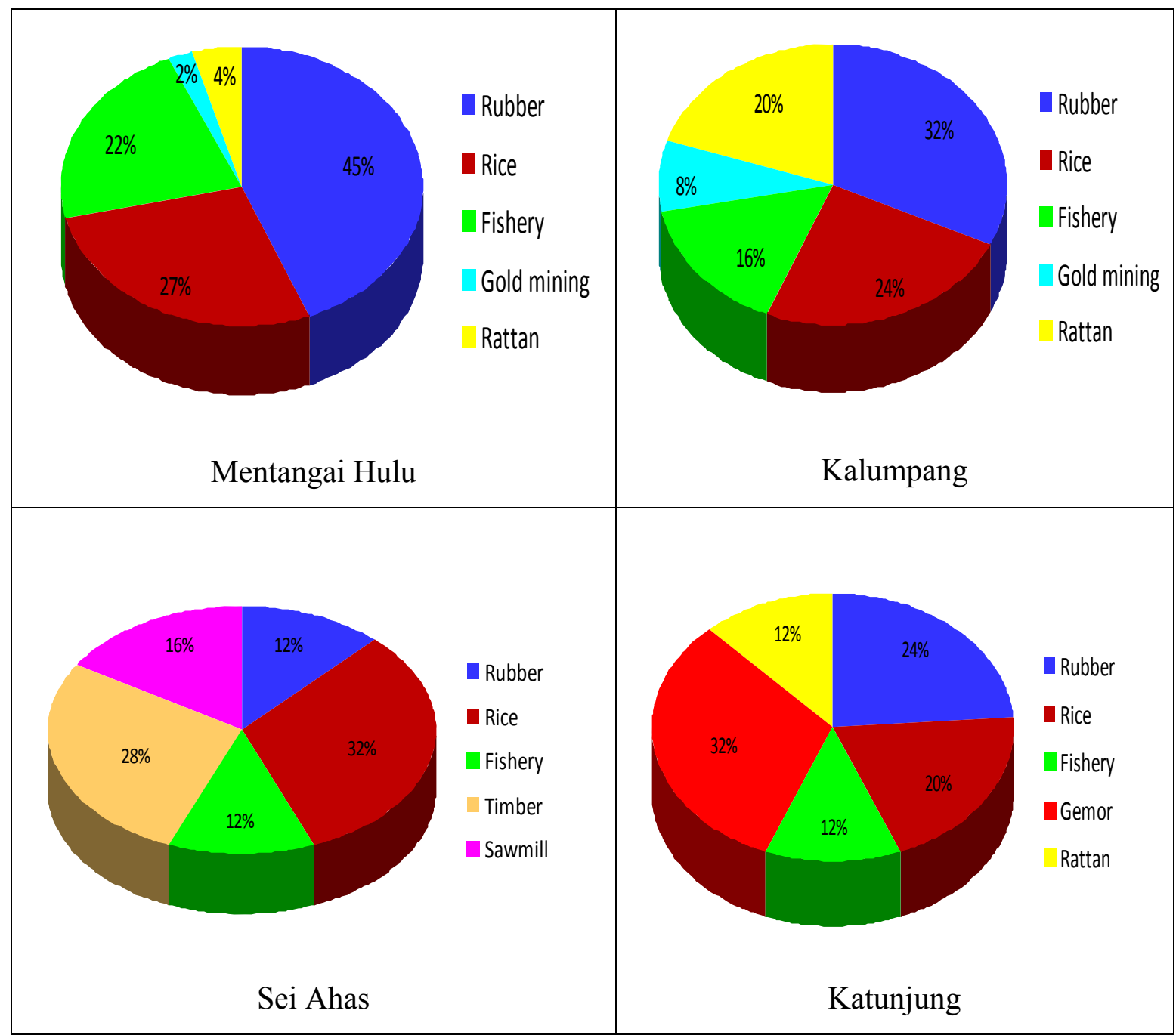

Figure 6. Top five components of livelihood strategies in Block A villages 


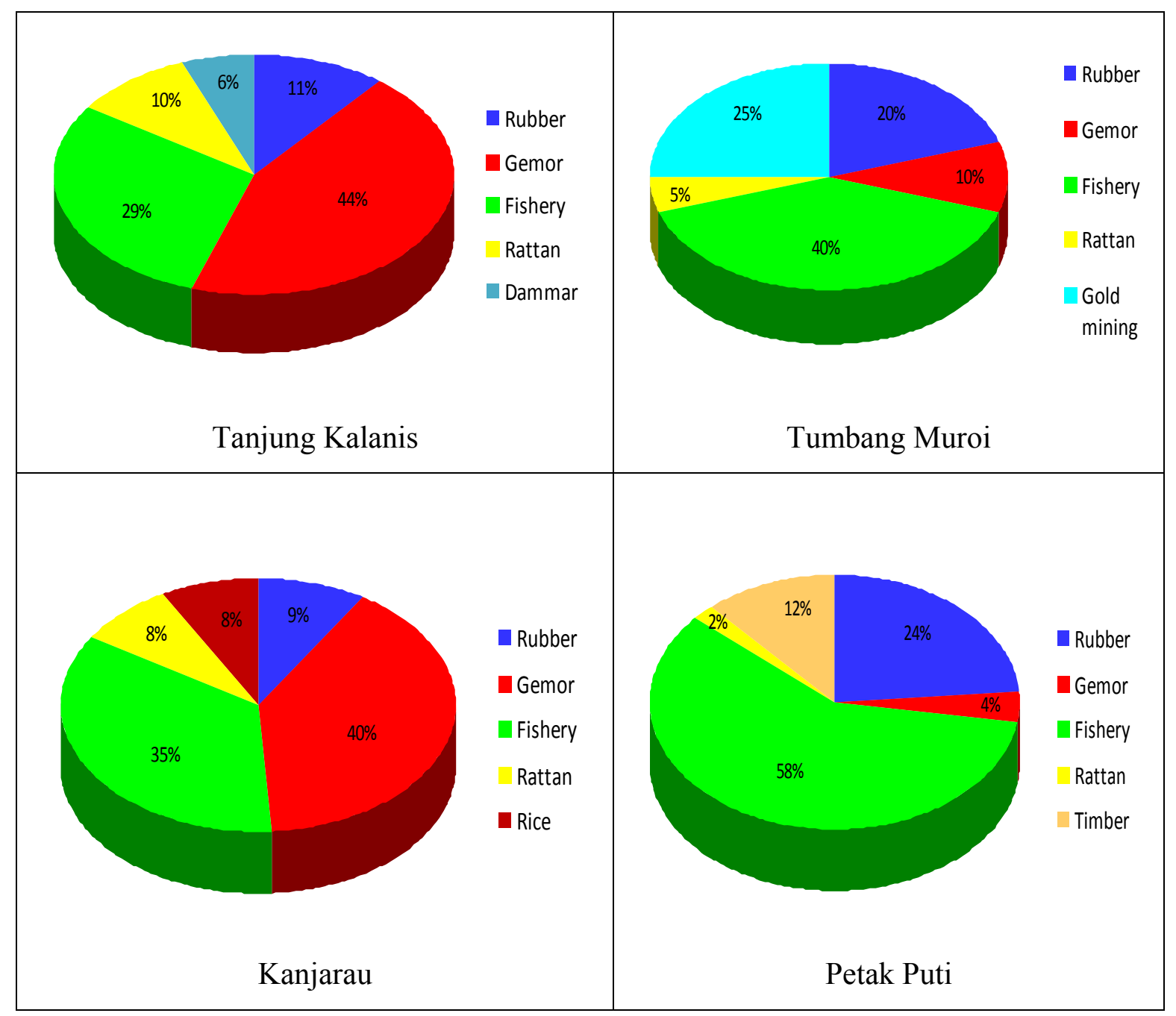

Figure 7. Top five components of livelihood strategies in Block E villages

\subsection{Change in the relative importance of livelihood source over time}

In this section the change in relative source of livelihood over time is analyzed using four time periods: prior to 1970, before the Mega Rice Project (1970-1995), after the Mega Rice Project (1996-2006), and 2007-2008. The time classification was draw based on policies changed that affected of local livelihoods. Those policies were (1). Policy on forest concessions in 1970's; (2). Mega rice project in 1995/1996; (3). Combating of illegal logging since 1995 and (4). Banning of using fire for land clearing since 2007.

There were six important sources of livelihood: swidden-rice cultivation, smallholder plantations, forest timber extraction, non-timber forest products, fishing and labor. Figures 6 and 7 show the relative importance of the source of livelihood for each village in Blocks A and $\mathrm{E}$, respectively. 


\subsubsection{Prior to 1970}

In the period prior to 1970 , local people were not yet logging timber for commercial purposes. Timber was used for their own consumption, such as for house construction and boats (klotok). Non-timber forest products such as rattan, dammar, jelutung, gaharu ramin, katiau, kalanis, ehang, nyatu and animals (snake, bird and deer) were very important sources of livelihood. Swidden-rice cultivation was practiced both in Block A and Block E. Fishing for local consumption was a very important source of livelihood. Smallholder plantations were not yet being actively developed.

\subsubsection{Before the Mega Rice Project (1970-1996)}

The relative importance of the means of livelihood changed dramatically in the period 19702006 before the Mega Rice Project, in association with the commencement of commercial logging. Large-scale commercial logging in Indonesia started in 1967, when the government of Indonesia took control of forest management in the country. They initiated a mechanism of concessions that allocated forest management to privately owned companies. The distribution of forest under the control of private logging companies made Indonesia the world's largest exporter of tropical timber, shipping nearly 300 million $\mathrm{m}^{3}$ to international markets during the 1970's (Barr, 2001). The timber concession companies: PT. Mangkatib Raya I, PT. Mangkatib Raya II, PT. Jayanti Jaya, PT. Sumber Alam and PT Sumber Usaha operated in the study area in the early 1970's logging commercial timber in the original mature high forests. The logging of commercial timber became the most important source of villager livelihood. Respondents said that in that period, villagers became rich from the logging. The non-timber forest products became less important.

\subsubsection{After the Mega Rice Project (1997-2006)}

After the Mega Rice Project, the relative importance of logging timber began to decline. Smallholder plantations (mostly rubber and rattan) and swidden-rice cultivation were very important in Block A, while in Block E, non-timber forest products and fishing were more important sources of livelihood. One exception was labor/working in gold mining that was important in Tumbang Muroi village in Block E.

\subsubsection{The current situation (>2007)}

After 2007, in the lower parts of the study area (Mentangai hulu and Kalumpang villages), smallholder plantations and swidden-rice cultivation became the most important sources of livelihood, followed by fishing. Timber and non-timber forest extraction were of lesser importance. In the middle part of the study area (Sei Ahas and Katunjung villages), the forest was still an important source of livelihood,especially for gemor.

In the upper streams of the area (Block E), livelihood from agriculture (rice and smallholder plantations) became less important, although there had been a tendency to develop rubber plantations in recent years. Non-timber forest products (gemor and rattan) and fishing were major sources of livelihood. 


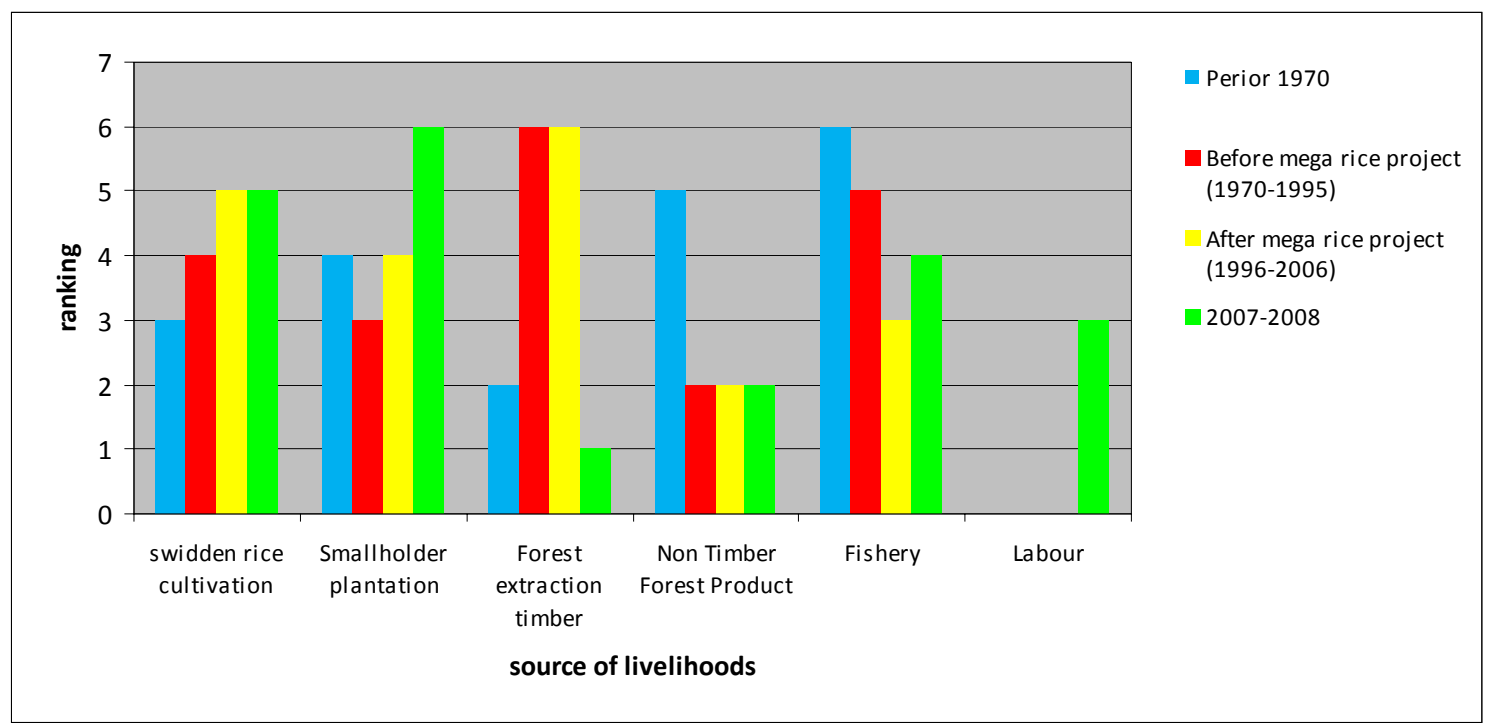

Figure 8. Importance ranking of livelihood components in Mantangai Hulu Block A.

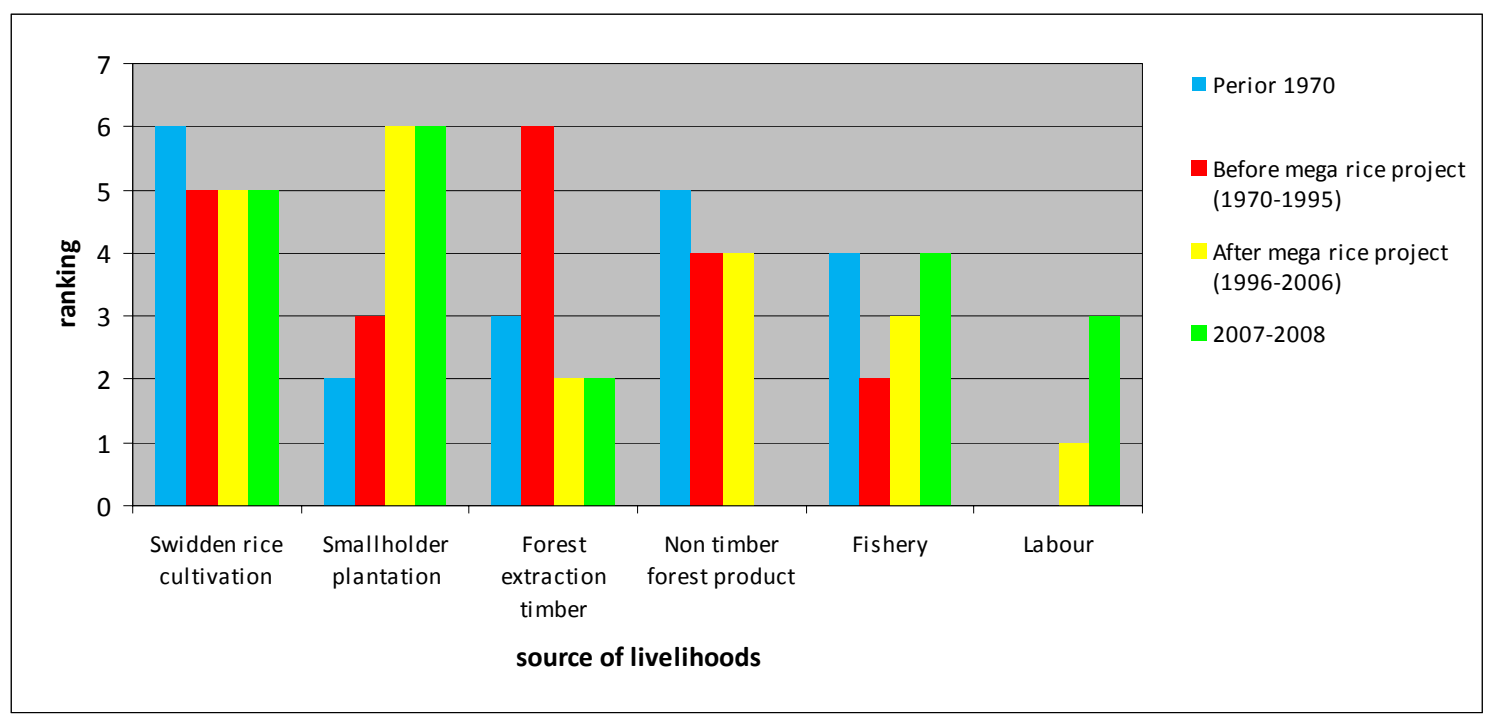

Figure 9. Importance ranking of livelihood components in Kalumpang (Block A) 


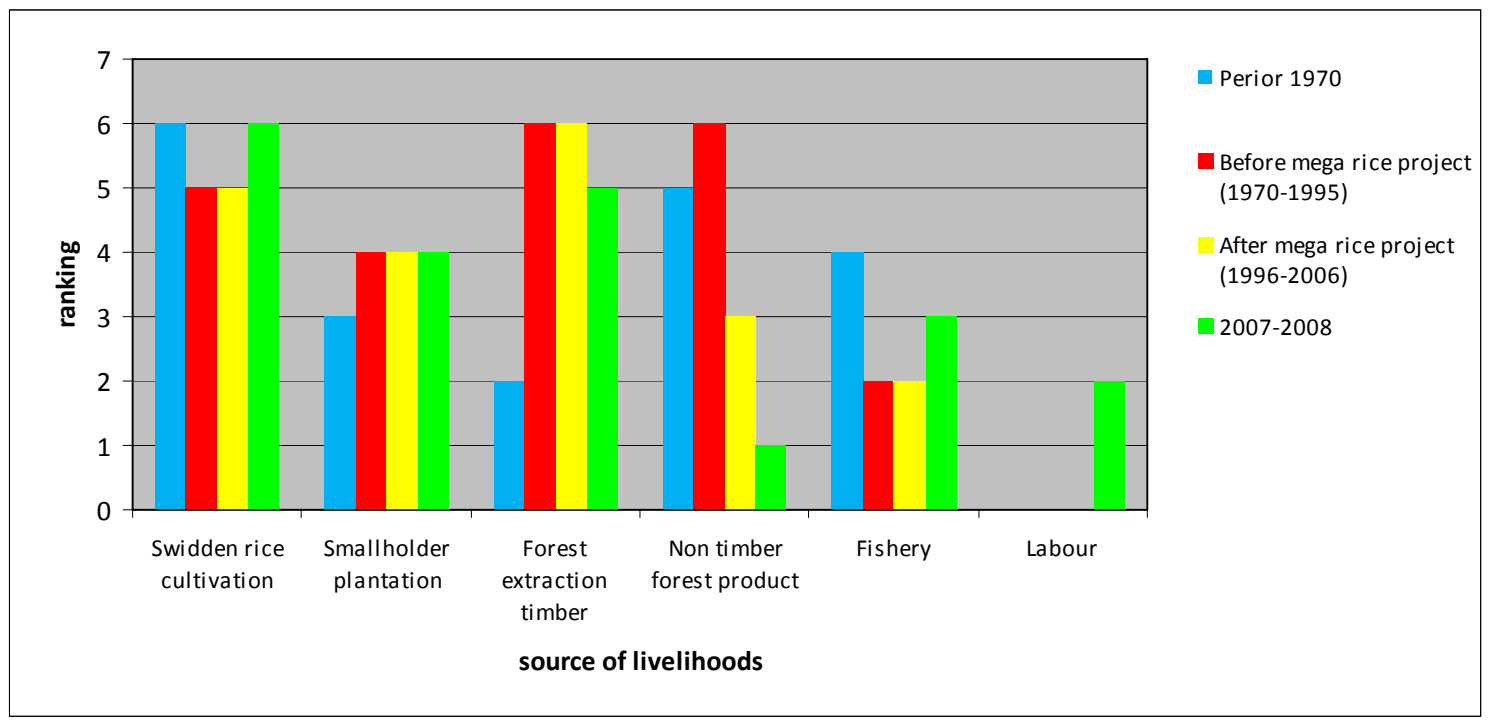

Figure 10. Importance ranking of livelihood components in Sei Ahas Block A.

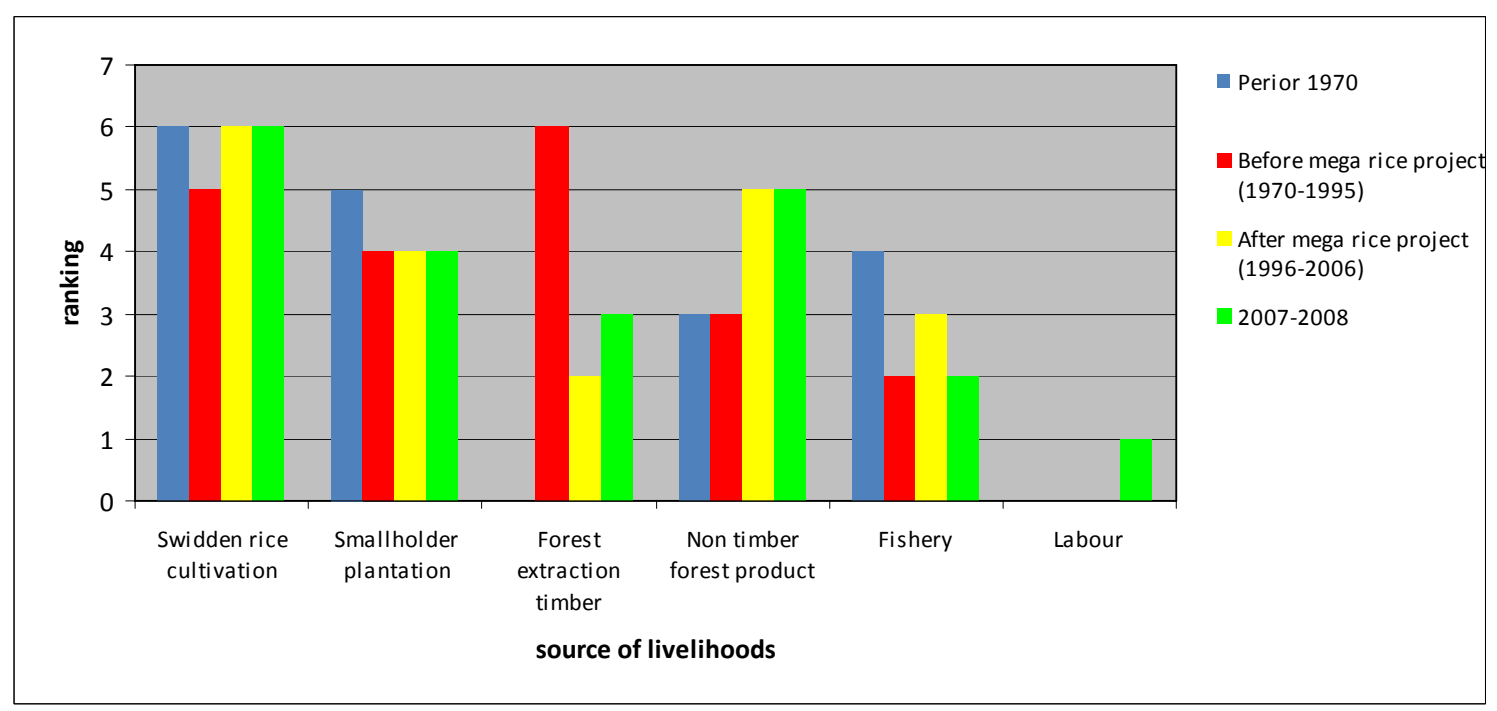

Figure 11. Importance ranking of livelihood components in Katunjung Block A. 


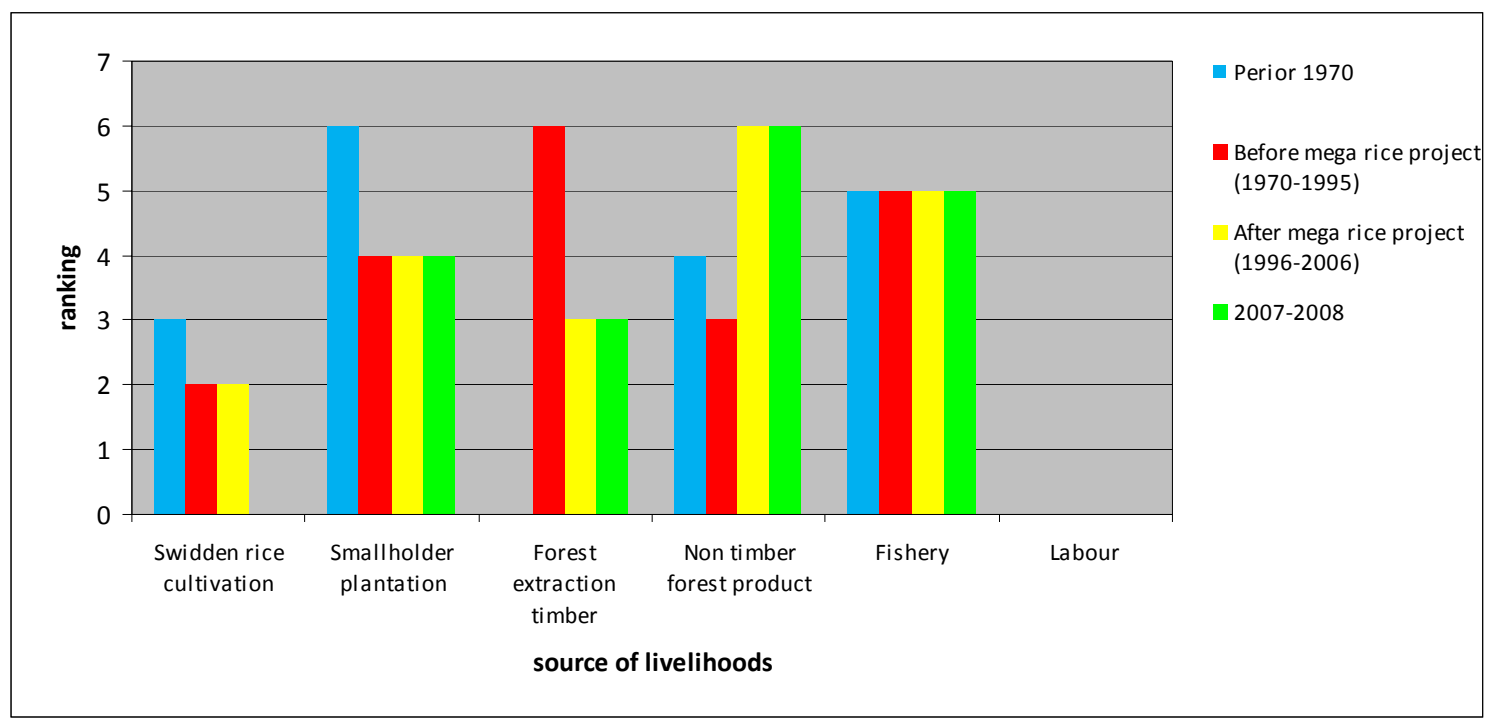

Figure 12. Importance ranking of livelihood components in Tanjung Kalanis Block E.

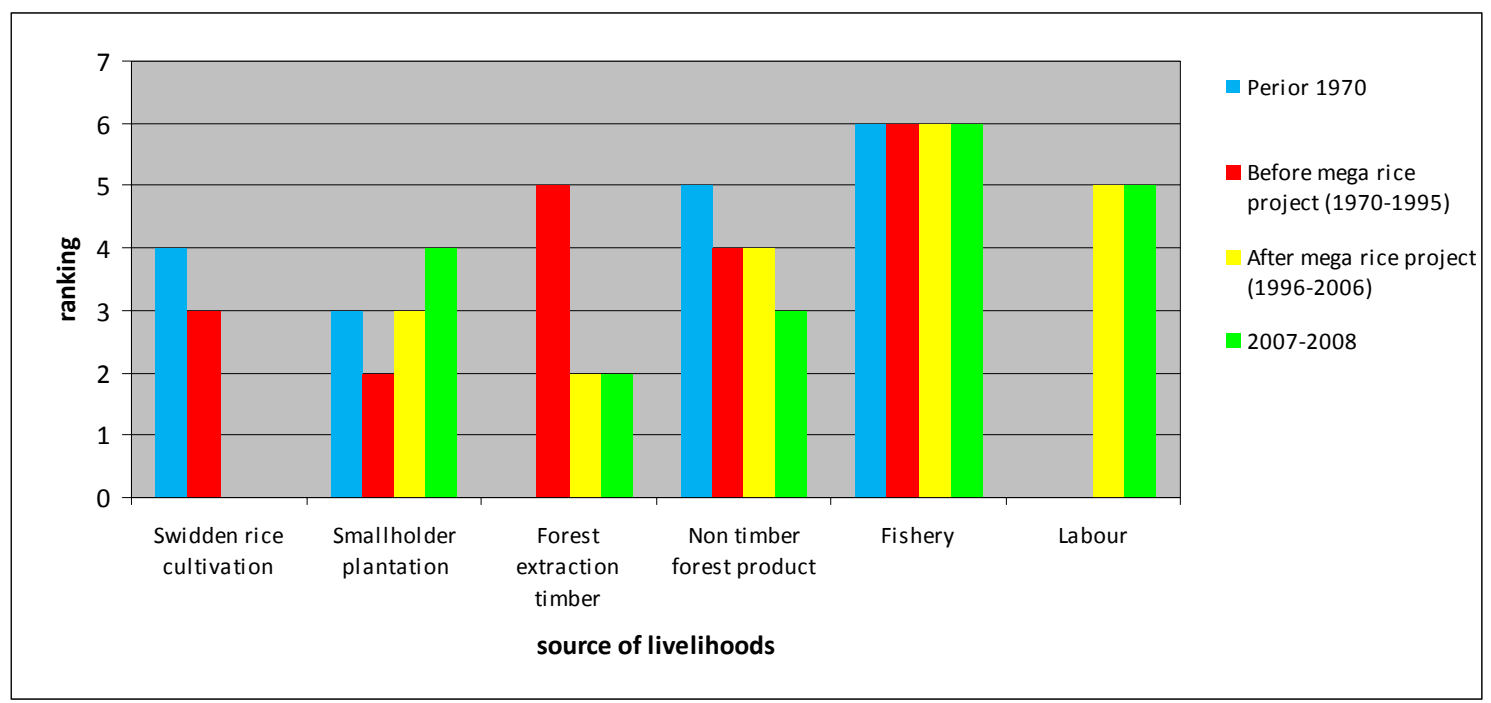

Figure 13. Importance ranking of livelihood components in Tumbang Muroi Block E. 


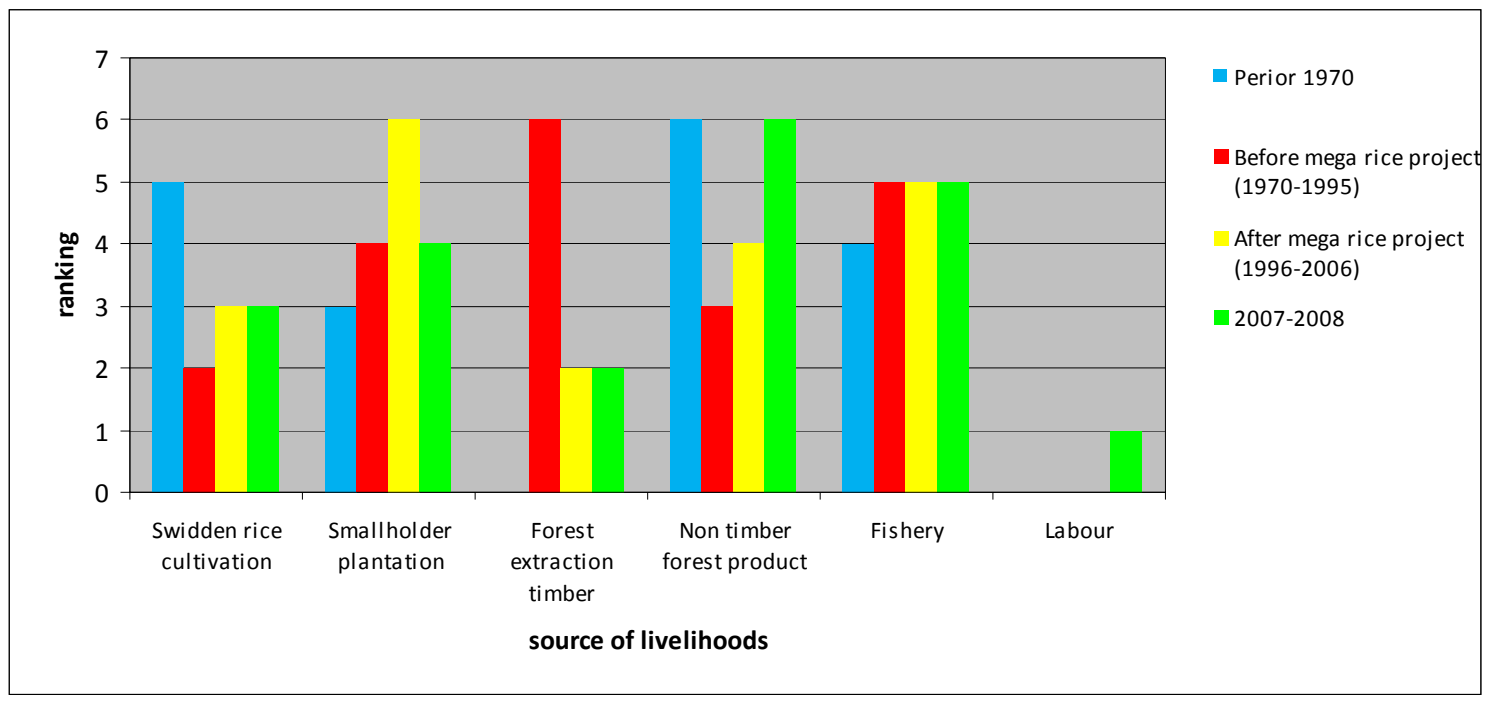

Figure 14. Importance ranking of livelihood components in Kanjarau Block E.

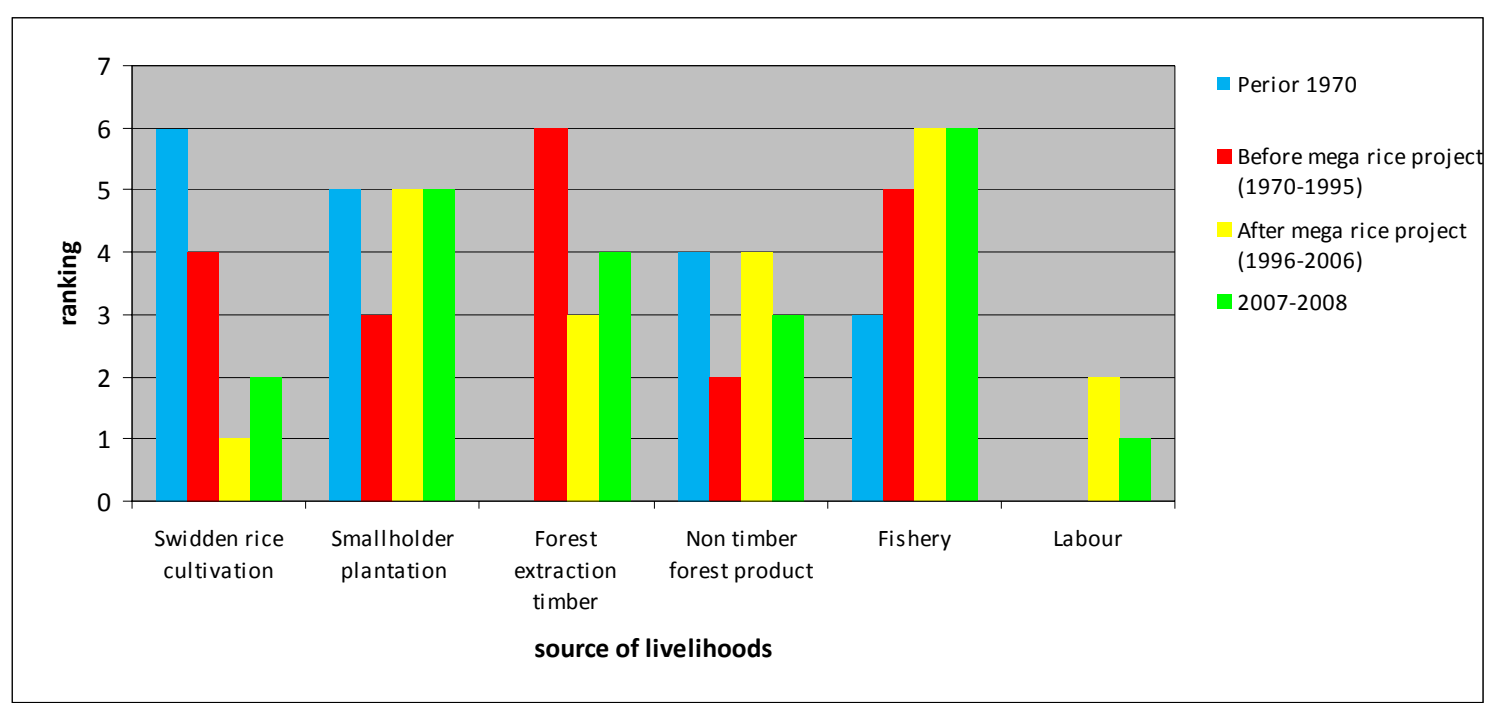

Figure 15. Importance ranking of livelihood components in Petak Puti Block E. 


\section{Poverty and equity}

\subsection{Poverty indicators: participatory assessment}

Using the participatory approach, villagers who participated in focus group discussions were asked to identify the indicators of poverty. Poverty indicators identified were:

(i) Do not have a permanent job

(ii) Do not have land

(iii) Income less than IDR 50000 per day per household

(iv) Housing:

- Quality of house made from low quality of timber

- Small size of house in corresponding to size of household

- Do not have house

(v) Unable to send children to school

(vi) Unable to buy clothing

(vii) Unable to buy medicine if sick

(viii) Do not have a boat

(ix) Eat less than three times a day

The poverty indicators discussed by the villagers were not only based on income, but ranged more widely including: education, health, jobs, and quality of the house. These indicators are similar to the components of the human development index (HDI). The HDI provides a composite measure of three dimensions of human development: living a long and healthy life (measured by life expectancy), being educated (measured by adult literacy and enrolment at the primary, secondary and tertiary levels) and having a decent standard of living (income). The HDI for Indonesia in 2005 was 0.728 , which gave the country a rank of 107 out of 177 countries. Life expectancy was 69.7 years, with the adult literacy rate (for age 15 and older) $90.4 \%$, and the combined primary, secondary and tertiary gross enrolment ratio was $68.2 \%$. (Human Development Index Report, 2008). From a sub-sample of 60 respondents, two poverty indicators were calculated (Table 12). The adult literacy rate in the study area was $98.7 \%$, being slightly higher than at the provincial and national levels. However, the school dropout rate for ages 7-12 years and ages 13-15 years were higher than the provincial and national figures. The school dropout rate for ages 13-15 year was very high (24\%). This indicated a problem in education at the junior high school level. It seems that the Program wajib belajar 9 tahun (the compulsory education program) in the study area had not been a success. 
Table 12. Poverty indicators in education.

\begin{tabular}{|c|c|c|c|}
\hline Indicators & Study Site & $\begin{array}{l}\text { Central Kalimantan } \\
\text { (2007) }\end{array}$ & National (2007) \\
\hline $\begin{array}{c}\text { Adult literacy rate (\%) } \\
\text { Ages } 15-55 \text { years }\end{array}$ & 98.7 & 98.05 & 88.07 \\
\hline $\begin{array}{c}\text { School Dropout }(\%) \text { : } \\
\text { Ages } 7-12 \text { years } \\
\text { Ages } 13-15 \text { years }\end{array}$ & $\begin{array}{r}3.0 \\
24.0\end{array}$ & $\begin{array}{l}0.81 \\
4.30\end{array}$ & $\begin{array}{l}0.67 \\
4.21\end{array}$ \\
\hline
\end{tabular}

Others poverty indicators are BLT (Bantuan Langsung Tunai) and Raskin (Bantuan Beras Untuk Keluarga Miskin) (Table 13). BLT represents the government's effort to anticipate the effect of the increase in fuel price on poor households. Under this program, poor households receive IDR 200000 per month. Raskin is also a government program for poverty alleviation. Under this program, poor households receive $20 \mathrm{~kg}$ rice/month. In the study area, however, rice from this program was distributed equally to all members of the village.

Table 13. Number of households receiving BLT and Raskin in 2008.

\begin{tabular}{|c|c|c|c|c|}
\hline \multirow[t]{2}{*}{ Village } & \multicolumn{2}{|c|}{ Raskin } & \multicolumn{2}{|c|}{ BLT } \\
\hline & $\begin{array}{c}\text { No. } \\
\text { Households }\end{array}$ & Percentage & $\begin{array}{c}\text { No. } \\
\text { Households }\end{array}$ & Percentage \\
\hline Mantangai Hulu & 178 & 35 & 178 & 35 \\
\hline Kalumpang & 64 & 22 & 87 & 23 \\
\hline Sei Ahas & 110 & 48 & 62 & 27 \\
\hline Katunjung & 149 & 25 & 138 & 23 \\
\hline Tanjung Kalanis & 110 & 100 & 0 & 0 \\
\hline Tumbang Muroi & 156 & 38 & 124 & 30 \\
\hline Kanjarau & 112 & 100 & 54 & 48 \\
\hline Petak Puti & 182 & 76 & 154 & 65 \\
\hline
\end{tabular}

\subsection{Expenditure analysis}

An expenditure survey was conducted in the study area using the Susenas (The National Socioeconomic Survey) questionnaire, so that the results could be compared to the Government/BPS data.

Table 14 shows the share of expenditure on food and non food items in the study area and at the provincial level. The share of expenditure on food is used as an indicator of poverty. Following Engel's Law, in a famous study using budget data for 153 Belgian families, Engel found that the lower a family's income, the greater was the proportion of their income that was spent on food.

There was not much difference between the monthly average expenditure per capita per month in Block A (IDR 330 598) and Block E (IDR 347 809) and it was slightly lower than the monthly average expenditure per capita per month at the provincial level in 2007 (IDR 363 845). The share of expenditure on food both in Block A and Block E was very high (75$79 \%)$; it was higher than at the provincial level in 2008 (65\%). Consequently, the share of expenditure on non food items was very low $(21-25 \%)$ and was lower than at the provincial level (35\%) (Table 14). 
The pattern of expenditure on food consumption between Block A and Block E was almost similar with a high share for cereals (17-26\%) and a lower share for meat (1\%), and eggs and milk (3\%). However, consumption of fish was high (12-13\%), as fishing was a major livelihood in the study area. Consumption of tobacco was high (8-12\%). Compared with the provincial level, the consumption of cereals in the study area was higher, consumption of meat, eggs and milk lower, consumption of fish higher and consumption of tobacco also higher.

The analysis of expenditure indicated that villagers in the study area were poorer than average at the provincial level.

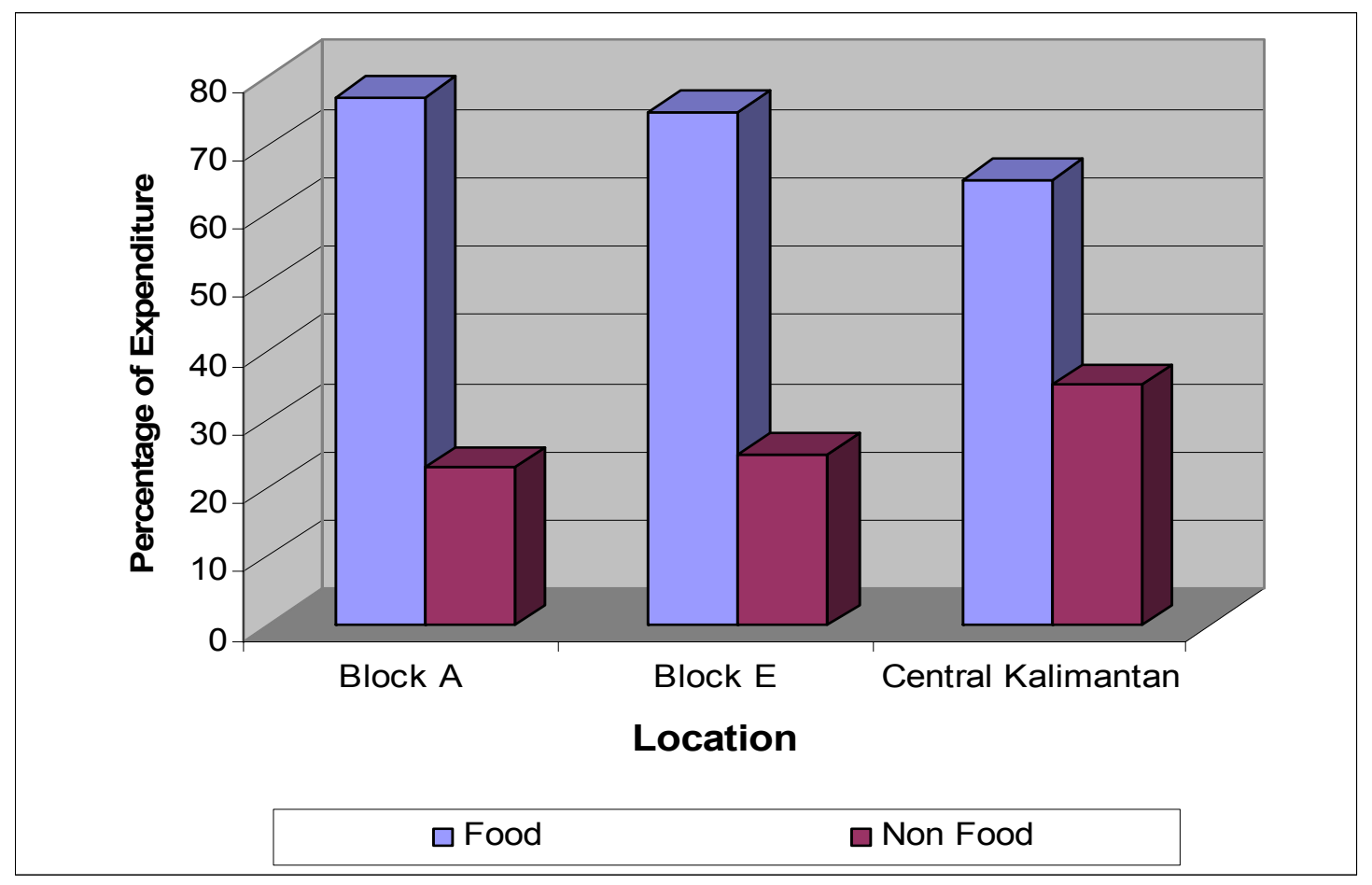

Figure 16. Household expenditure by commodity group (\%) 
Table 14. Monthly average expenditure per capita (IDR) by commodity group.

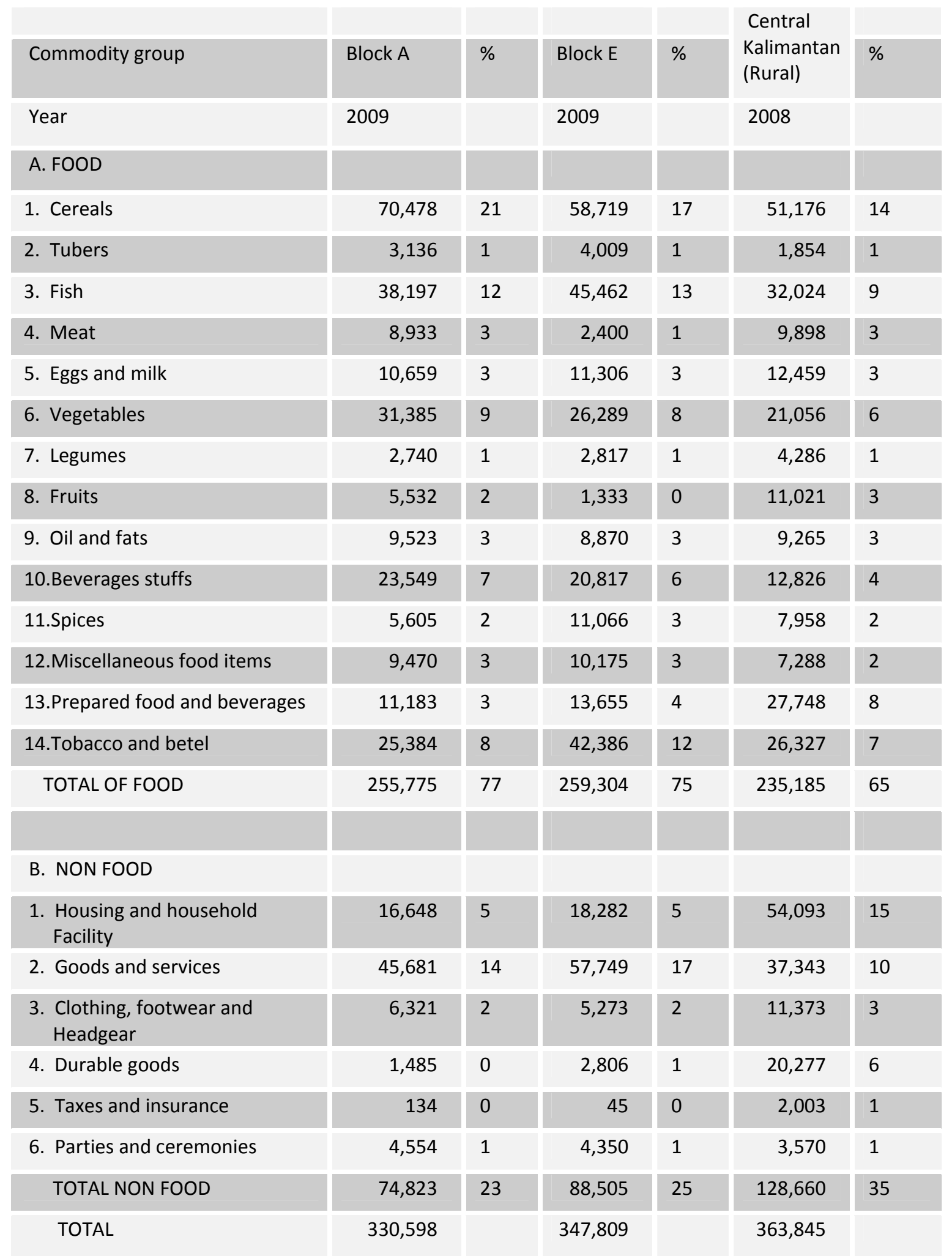

The "poverty line" in Indonesia is calculated based on the daily minimum requirement of 2 $100 \mathrm{kcal}$ per capita plus a non-food minimum requirement, for living, clothing, schooling, transportation, household necessities, and other basic individual needs. Data for calculating 
the poverty line came from the Socio Economic Survey (Susenas) that was carried out by BPS (the Statistic Bureau).

Table 15. Poverty line data and number of people below the poverty line for regions in Indonesia.

\begin{tabular}{|c|c|c|c|}
\hline Level & $\begin{array}{l}\text { Poverty line (expenditure } \\
\text { per capita/month) }\end{array}$ & $\begin{array}{c}\text { Population } \\
\text { below poverty } \\
\text { line } \\
(000)\end{array}$ & $\begin{array}{c}\text { Percentage of } \\
\text { population } \\
\text { below poverty } \\
\text { line (\%) }\end{array}$ \\
\hline $\begin{array}{lc}\text { National Level: } & 2007 \\
& 2008\end{array}$ & $\begin{array}{l}166,697 \\
182,636\end{array}$ & $\begin{array}{l}37,168 \\
34,960\end{array}$ & $\begin{array}{l}16.58 \\
15.42\end{array}$ \\
\hline $\begin{array}{r}\text { Central Kalimantan: } 2007 \\
2008\end{array}$ & $\begin{array}{l}162,266 \\
186,003\end{array}$ & $\begin{array}{l}210.3 \\
200.0\end{array}$ & $\begin{array}{l}9.38 \\
8.71\end{array}$ \\
\hline Kapuas District: & 125,410 & 36.8 & 9.30 \\
\hline $\begin{array}{l}\text { Study Area: } \\
\text { Block A and } E\end{array}$ & - & - & 8.33 \\
\hline
\end{tabular}

Data sources: 1) National, Provincial and district. Biro Pusat Statistik. 2007. Data dan Informasi Kemiskinan Tahun 2007 and http://kalteng.bps.go.

The poverty line at the national level in 2008 was IDR 182636 per capita per month. The number of people below the poverty line was 34.960 million or $15.42 \%$. The percentage of the population below the poverty line in $2008(15.42 \%)$ was less than in 2007 (16.58\%) (Table 15).

At the provincial level for Central Kalimantan, the poverty line in 2007 was IDR 186003 per capita per month. The percentage of the population below the poverty line was $8.71 \%$, lower than the national level. Compared to 2007, the number of people below the poverty line decreased by $5.9 \%$.

At the district level for Kapuas district, in 2007 the percentage of the population below the poverty line was $9.30 \%$, lower than the national and provincial levels.

Using the poverty line data for Central Kalimantan in 2008 (IDR 186003 per capita per month), the percentage of the population below the poverty line in the study area was estimated to be $8.33 \%$.

\subsection{Income analysis}

The calculation of income included the value of commodities consumed, with $95 \%$ of income from swidden-rice cultivation and $37 \%$ of income from fishing in Block A being consumable income. In Block E, $56 \%$ of income from swidden-rice cultivation and $13 \%$ of income from fishing made up the consumable income. Other sources of income, such as from smallholder plantations and forest extraction were mostly cash.

While the average total income per year per household in Block E was slightly higher than in Block A, the composition of income sources was very different. Agriculture was the major source of income in Block A, while forest extraction was the major source of income in Block E. 


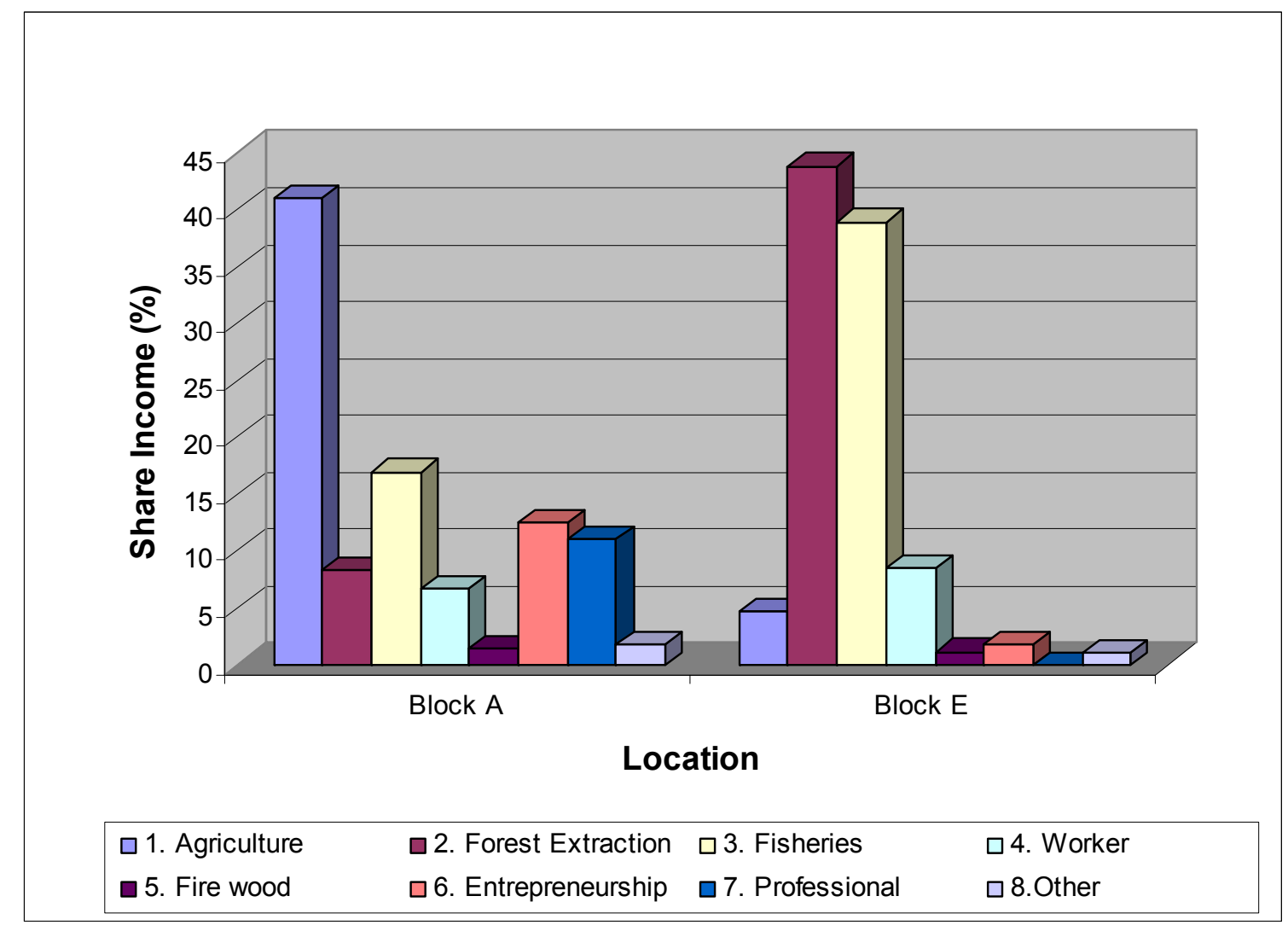

Figure 17. Household income by activity type (\%) 
In Block A, the highest source of income was from rubber (31\%), followed by fishing (17\%), entrepreneurial activities (12.6\%) and professional work (11.0\%). Swidden-rice cultivation was also important (9.0\%). Income from forest extraction was low (8.40\%) (Table 16).

Table 16. Sources of income in Block A and Block E in 2008.

\begin{tabular}{|c|c|c|c|c|c|c|}
\hline \multirow{3}{*}{ Sources of Income } & \multicolumn{4}{|c|}{ Income per Household } & \multicolumn{2}{|c|}{ Income per Capita } \\
\hline & \multicolumn{2}{|c|}{ Block A } & \multicolumn{2}{|c|}{ Block E } & \multirow{2}{*}{$\begin{array}{l}\text { Block A } \\
\text { Rupiah }\end{array}$} & \multirow{2}{*}{$\begin{array}{l}\text { Block E } \\
\text { Rupiah }\end{array}$} \\
\hline & Rupiah & $\%$ & Rupiah & $\%$ & & \\
\hline \multicolumn{7}{|l|}{ 1. Agriculture } \\
\hline Swidden-rice cultivation & $1,447,083$ & 9.0 & 73,500 & 0.4 & 364,811 & 16,705 \\
\hline Rubber plantation & $5,023,573$ & 31.1 & 899,680 & 4.3 & $1,266,447$ & 204,473 \\
\hline Rattan plantation & 162,167 & 1.0 & 11,000 & 0.1 & 40,882 & 2,500 \\
\hline \multicolumn{7}{|l|}{ 2. Forest Extraction } \\
\hline Timber & $1,071,333$ & 6.6 & $1,081,667$ & 5.2 & 270,084 & 245,833 \\
\hline Gemor & 215,200 & 1.3 & $7,413,167$ & 35.3 & 54,252 & $1,684,811$ \\
\hline Rattan & 70,500 & 0.4 & 704,000 & 3.4 & 17,773 & 160,000 \\
\hline 3. Fishing & $2,737,967$ & 17.0 & $8,173,533$ & 39.0 & 690,244 & $1,857,621$ \\
\hline \multicolumn{7}{|l|}{ 4. Worker (laborer) } \\
\hline Gold mining & 120,000 & 0.7 & $1,363,633$ & 6.5 & 30,252 & 309,917 \\
\hline Sawmill & 238,000 & 1.5 & - & 0.0 & 60,000 & 0 \\
\hline Other & 717,000 & 4.4 & 423,333 & 2.0 & 180,756 & 96,212 \\
\hline 5. Firewood & 238,000 & 1.5 & 242,667 & 1.2 & 60,000 & 55,152 \\
\hline 6. Entrepreneurship & $2,031,333$ & 12.6 & 388,333 & 1.9 & 512,101 & 88,258 \\
\hline 7. Professional & $1,781,333$ & 11.0 & - & 0.0 & 449,076 & 0 \\
\hline 8. Other & 294,133 & 1.8 & 207,950 & 1.0 & 74,151 & 47,261 \\
\hline 9. Total Income Per Year & $16,147,623$ & 100 & $\begin{array}{r}20,982,46 \\
3\end{array}$ & 100 & $4,070,829$ & $4,768,742$ \\
\hline 10. Income per day & & & & & 11,153 & 13,065 \\
\hline
\end{tabular}

In contrast, fishing (39\%) and gemor extraction (35.3\%) were the major sources of income in Block E, with their total income share being $74.3 \%$. This indicated a high dependency on open access to natural resources. Other sources of income from open access to natural resources were timber logging (5.2\%) and rattan extraction from the forest (3.4\%). Income from working in gold mining represented $6.5 \%$. Although there was a tendency for rubber plantation establishment in Block E, its contribution to income was relatively low (4.3\%), as was that from rattan gardens (3.4\%). Swidden-rice cultivation was not common, accounting for just $0.4 \%$. 
Daily income per capita of respondents in Block A was IDR 11153 (USD \$1.09) and in Block E was IDR 13065 (USD \$1.28), while the average family size ranged from 3.97 to 4.4 members at both sites. Using the international poverty line standard of USD \$1 a day, the percentage of respondents living below the international poverty line in Block A (53\%) was higher than in Block E (33\%).

\subsection{Equity analysis}

In order to analyze the equity of income, decomposition analysis was applied using the Gini coefficient that ranges from 0 (equal distribution of income) to 1 (total concentration of income). Gini decomposition is commonly applied in economic analysis (Alderman and Garcia, 1993) using the Gini decomposition formula that was developed by Fei, Ranis, and Kuo (1978) and Pyatt, Chen, and Fei (1980). (See Appendix 1).

The computation results of the decomposed Gini ratios for income are shown in Table 17. The overall Gini ratios for income in Block A (0.26) and Block E (0.22) were relatively small. This indicated that incomes in both areas were equally distributed.

Nonetheless, the income from fishing reduced the overall inequality of income distribution at both sites, as the concentration coefficients were less than unity. This suggests that the income from fishing was relatively equally distributed, making this income important in reducing poverty and increasing income equality. In addition, about $97 \%$ of respondents engaged in fishing.

Forest extraction reduced the inequality of income in Block A but it increased the inequality of income in Block E. Since less forest area was available in Block A, with additional forest far away and thus costly to access, not many villagers in Block A were interested in working in forest extraction. However, the forest was an important income source for poor people who had limited income opportunities. In contrast, the forest areas in Block E were more available. Gemor was an important and valuable forest product. About $35.5 \%$ of income in Block E came from gemor and about $57 \%$ of respondents collected gemor.

The coefficient concentration for smallholder plantations (0.95) was almost unity in Block A, thus the impact on inequality was not very clear. In Block E, smallholder plantations reduced income inequality but the share of income was low (4.34\%).

Income from growing rice was more evenly distributed at both sites. However, in Block E only $7 \%$ of respondents were growing rice that only produced a very small share of income $(0.35 \%)$. Thus, the impact analysis on income inequality in Block $\mathrm{E}$ was not relevant.

Working, especially in gold mining, made up a very important share of total income (6.7$8.5 \%$ ) and the concentration coefficient was lower than unity for both sites, which implied a distribution that was equal. It is important to note that for poor farmers selling their labor is a very important income source.

${ }^{4}$ Average exchange rate in June 2009 was USD \$1 = IDR 10215. 
Collecting firewood also reduced income inequality at both sites. About $93-97 \%$ of respondents were involved in collecting firewood that was all used for household consumption.

Non-farm income (entrepreneurship and professional work) was more unequally distributed in Block A. Income from entrepreneurship accounted for $12.58 \%$ and income from professional work was $11.03 \%$ of total income. Most non-farm income came from professional work requiring higher skills, higher education and large amounts of capital, such as teaching, government positions, trading, rubber and rattan collecting, and commissioners. Therefore, non-farm income widened the income disparities between individuals and households in the community. However, in Block E, there were no professional workers among the respondents. Non-farm income came from one type of entrepreneurship only, namely warung (small shops). The income share from non-farm income was very low (1.85\%). This suggests the use of non-farm income to decrease income inequality in Block $\mathrm{E}$ was low.

Table 17. Income inequality in Block A and Block E in 2008.

\begin{tabular}{|c|c|c|c|c|c|c|}
\hline \multirow{2}{*}{ Source of income } & \multicolumn{3}{|c|}{ Block A } & \multicolumn{3}{|c|}{ Block E } \\
\hline & $\begin{array}{l}\text { Income } \\
\text { Share }\end{array}$ & $\begin{array}{l}\text { Coefficient } \\
\text { Concentration }\end{array}$ & $\begin{array}{l}\text { Pseudo } \\
\text { Gini ratio }\end{array}$ & $\begin{array}{l}\text { Income } \\
\text { Share }\end{array}$ & $\begin{array}{l}\text { Coefficient } \\
\text { Concentration }\end{array}$ & $\begin{array}{l}\text { Pseudo } \\
\text { Gini ratio }\end{array}$ \\
\hline \multicolumn{7}{|l|}{ 1. Agriculture } \\
\hline $\begin{array}{l}\text { Swidden-rice } \\
\text { Cultivation }\end{array}$ & 8.96 & 0.82 & 0.21 & 0.35 & 1.52 & 0.34 \\
\hline Tree plantation & 32.11 & 0.95 & 0.24 & 4.34 & 0.28 & 0.06 \\
\hline 2. Forest Extraction & 8.40 & 0.22 & 0.06 & 43.84 & 1.79 & 0.40 \\
\hline 3. Fishing & 16.96 & 0.15 & 0.04 & 38.95 & 0.76 & 0.17 \\
\hline 4. Worker (laborer) & 6.66 & 0.84 & 0.22 & 8.52 & 0.87 & 0.19 \\
\hline 5. Firewood & 1.47 & 0.43 & 0.11 & 1.16 & 0.43 & 0.10 \\
\hline 6. Entrepreneurship & 12.58 & 3.38 & 0.87 & 1.85 & 0.37 & 0.08 \\
\hline 7. Professional & 11.03 & 2.19 & 0.56 & 0.00 & 0.00 & 0.00 \\
\hline 8. Other & 1.82 & 0.6 & 0.15 & 0.99 & 1.53 & 0.34 \\
\hline Total Income & & & 0.26 & & & 0.22 \\
\hline
\end{tabular}




\section{Role of women in natural resource management}

In the study area, the women's involvement in production activities was quite prominent. For example, in every village women were influential in making decisions on what type of plants to cultivate on agricultural land. However, there were differences in the level of involvement. In the villages of Block A, women had an equal say with the men in choosing commodities to plant, except in Desa Kalumpang where women had less influence. In Block E, women had less influence in the same decisions, except in Desa Karanjau where women had an equal say.

Table 18. Participation by women in deciding type of plants to cultivate in Block A villages.

\begin{tabular}{|l|c|c|}
\hline Village & Participation by women & Level of participation \\
\hline Mantangai Hulu & Yes & Equal to men \\
\hline Kalumpang & Yes & Less than men \\
\hline Sei Ahas & Yes & Equal to men \\
\hline Katunjung & Yes & Equal to men \\
\hline
\end{tabular}

Table 19. Participation by women in deciding type of plants to cultivate in Block $E$ villages.

\begin{tabular}{|l|c|c|}
\hline Village & Participation by women & Level of participation \\
\hline Tanjung Kalanis & Yes & Less than men \\
\hline Tumbang Muroi & Yes & Less than men \\
\hline Kanjarau & Yes & Equal to men \\
\hline Petak Puti & Yes & Less than men \\
\hline
\end{tabular}

Participation by women also extended to various livelihood options. In Block E, women's participation in livelihood activities was more pronounced than in Block A. In Block E, women were involved in 10 livelihood activities, particularly rubber tapping and fishing. In Block A women were only involved in eight activities including rubber tapping and swiddenrice cultivation. 


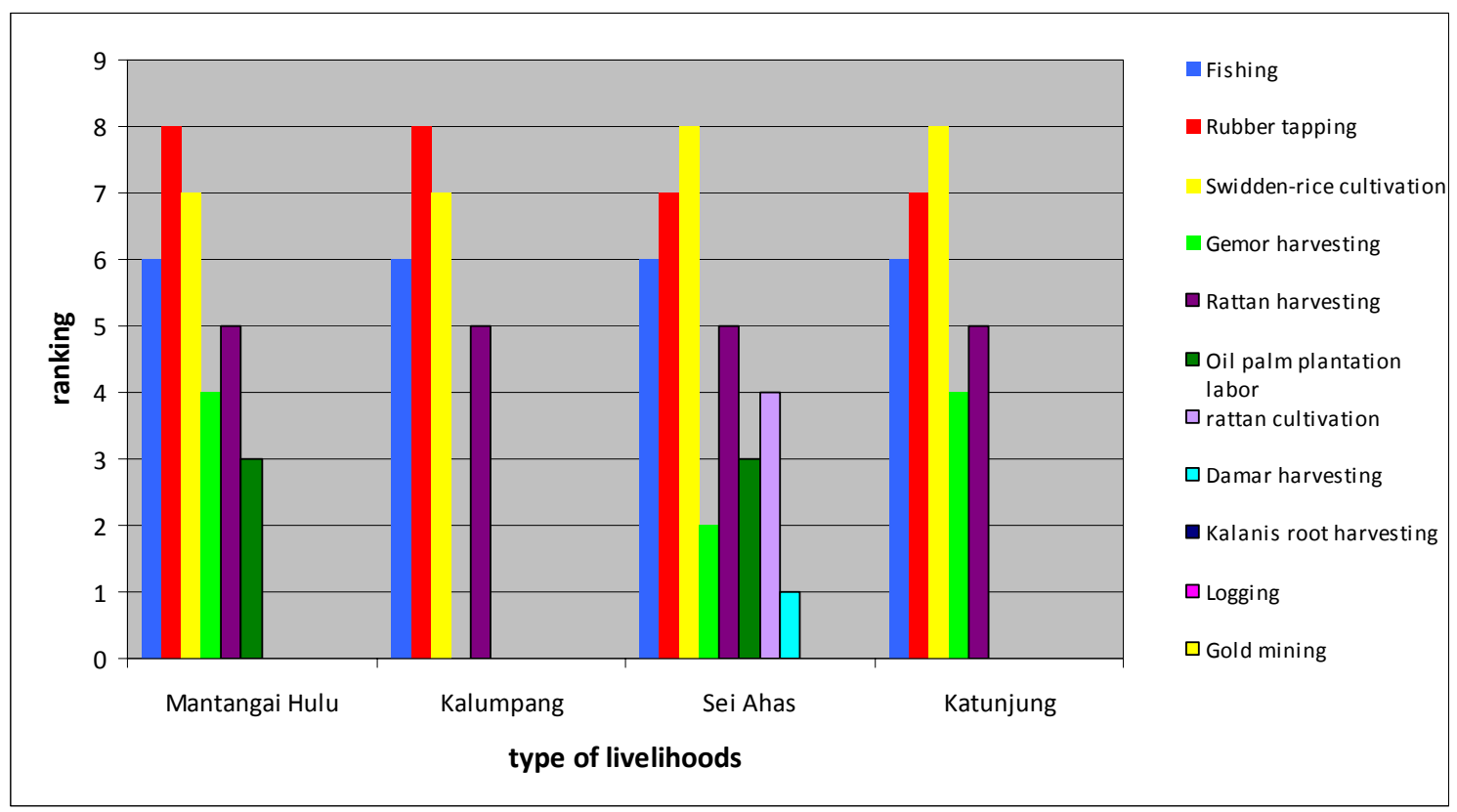

Figure 18. Participation by women in livelihood options of villages in Block A.

(The $\mathrm{Y}$ axis refers to ranking).

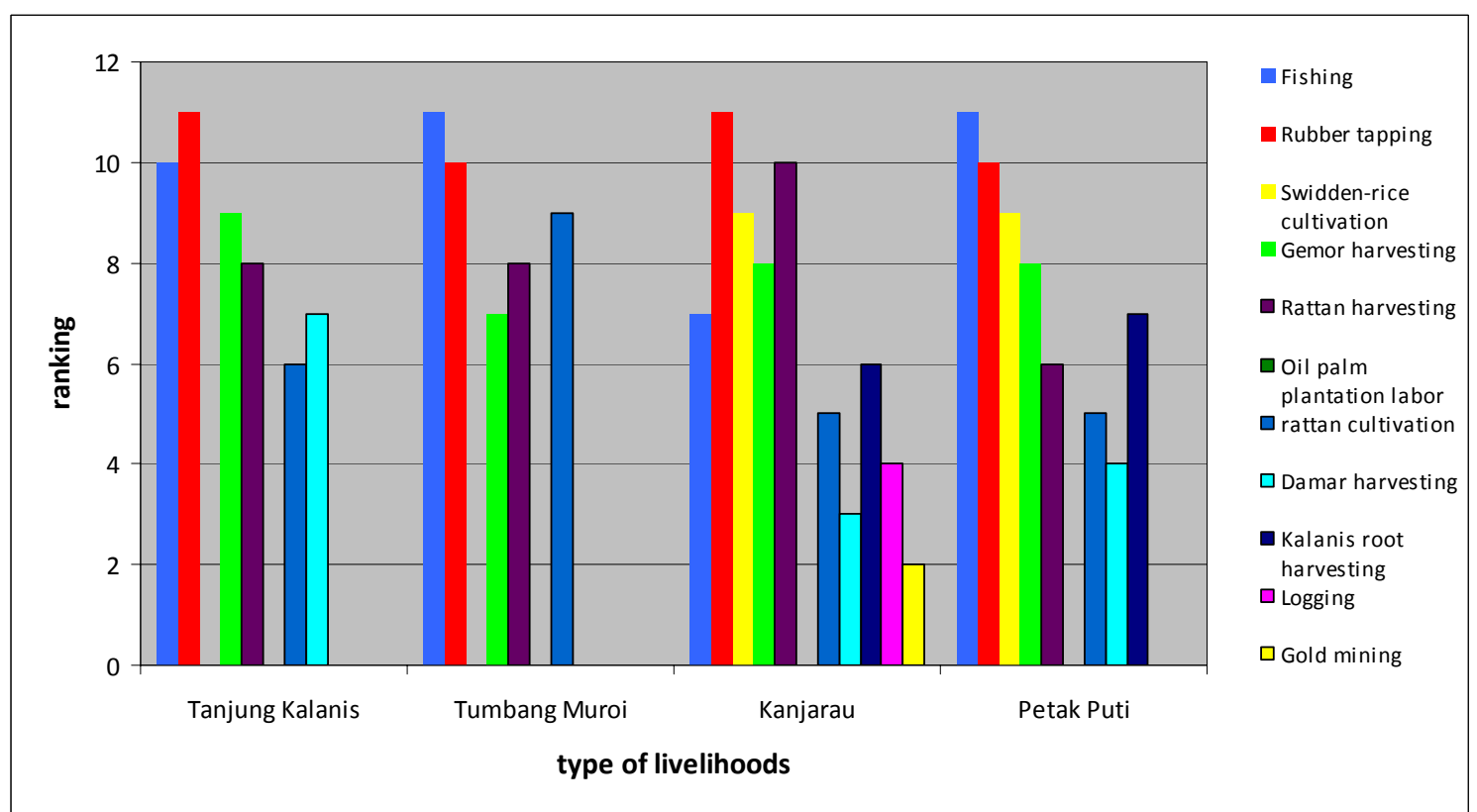

Figure 19. Participation by women in livelihood options in villages in Block E.

(The $\mathrm{Y}$ axis refers to ranking).

The of participation by women in livelihood activities varied. In some livelihood activities like fishing, rubber tapping, swidden-rice cultivation, rattan and kalanis root harvesting, the level of participation by women was higher than by men. Although in general women participated in livelihood activities less than men, they contributed substantially to household 
income. This contribution was often hidden. Household income was often seen as income solely acquired by men, rather than a joint effort.

Table 20. Participation by women in various livelihood options in Block A.

\begin{tabular}{|l|c|c|c|c|}
\hline \multicolumn{1}{|c|}{ Livelihood options } & \multicolumn{2}{c|}{ Participation by Women in Livelihood Options } \\
\hline & $\begin{array}{c}\text { Mantangai } \\
\text { Hulu }\end{array}$ & Kalumpang & Sei Ahas & Katunjung \\
\hline Fishing & $*$ & $*$ & $* * *$ & $* * *$ \\
\hline Rubber tapping & $* * *$ & $* *$ & $* *$ & $* *$ \\
\hline Swidden-rice cultivation & $*$ & $*$ & $* * *$ & $* *$ \\
\hline Gemor harvesting & $*$ & - & $*$ & $*$ \\
\hline Rattan harvesting & $*$ & $*$ & $* *$ & - \\
\hline Oil palm plantation labor & $* *$ & - & $*$ & - \\
\hline Rattan cultivation & - & - & $* *$ & - \\
\hline $\begin{array}{l}\text { Damar harvesting } \\
\text { Kalanis root harvesting }\end{array}$ & - & - & - & - \\
\hline Logging/carpentry & - & - & - & - \\
\hline Gold mining & - & - & - & - \\
\hline Note: $*$
\end{tabular}

Table 21. Participation by women in various livelihood options in Block E.

\begin{tabular}{|c|c|c|c|c|}
\hline \multirow[t]{2}{*}{ Livelihood options } & \multicolumn{4}{|c|}{ Participation by Women in Livelihood Options } \\
\hline & $\begin{array}{l}\text { Tanjung } \\
\text { Kalanis }\end{array}$ & $\begin{array}{c}\text { Tumbang } \\
\text { Muroi }\end{array}$ & Kanjarau & Petak Puti \\
\hline Fishing & $* *$ & $* *$ & $* * *$ & $* *$ \\
\hline Rubber tapping & $* * *$ & $*$ & $* * *$ & $*$ \\
\hline Swidden-rice cultivation & - & - & $* * *$ & $* * *$ \\
\hline Gemor harvesting & * & $*$ & $*$ & $*$ \\
\hline Rattan harvesting & $* * *$ & $* *$ & $* * *$ & $* * *$ \\
\hline Oil palm plantation labor & - & - & - & - \\
\hline Rattan cultivation & $*$ & $*$ & $*$ & $*$ \\
\hline Damar harvesting & $*$ & - & $*$ & $*$ \\
\hline Kalanis root harvesting & - & - & $* * *$ & $*$ \\
\hline Logging/carpentry & - & - & $*$ & - \\
\hline Gold mining & - & - & $*$ & - \\
\hline
\end{tabular}

Another important role played by women was in the marketing of products. According to respondents, women had a better bargaining position in transactions and greater market knowledge than men. 
Table 22. Participation by women in the sale of products in villages in Block A.

\begin{tabular}{|l|c|l|l|}
\hline \multicolumn{1}{|c|}{ Villages } & $\begin{array}{c}\text { Participation by } \\
\text { Women in the Sale } \\
\text { of Products }\end{array}$ & $\begin{array}{c}\text { Level of } \\
\text { Participation }\end{array}$ & \multicolumn{1}{|c|}{ Impact } \\
\hline Mantangai Hulu & Yes & More than men & Higher/better price \\
\hline Kalumpang & Yes & More than men & Higher/better price \\
\hline Sei Ahas & Yes & More than men & Higher/better price \\
\hline Katunjung & Yes & Equal to men & $\begin{array}{l}\text { None because product prices } \\
\text { are fixed }\end{array}$ \\
\hline
\end{tabular}

Table 23. Participation by women in the sale of products in villages in Block E.

\begin{tabular}{|l|l|l|l|}
\hline \multicolumn{1}{|c|}{ Villages } & $\begin{array}{c}\text { Participation by } \\
\text { Women in the Sale } \\
\text { of Products }\end{array}$ & $\begin{array}{c}\text { Level of } \\
\text { Participation }\end{array}$ & \multicolumn{1}{|c|}{ Impact } \\
\hline Tanjung Kalanis & Yes & More than men & Higher/better price \\
\hline Tumbang Muroi & Yes & More than men & Higher/better price \\
\hline Kanjarau & Yes & More than men & Higher/better price \\
\hline Petak Puti & Yes & More than men & Higher/better price \\
\hline
\end{tabular}




\section{Profitability analysis}

In this section, return to land (profitability) and return to labor (income) of rubber and swidden-rice cultivation were analyzed. Return to land (profitability) was defined as gross revenue minus the actual and imputed costs of hired and family labor, and current inputs. Return to labor (income) was defined as gross revenue minus paid-out costs. While profit was supposed to estimate returns to land and management effort and efficiency, the income also included returns from family labor. Although theoretically, profit is preferable as an indicator of efficiency, the measured profit may suffer from bias to the extent that the shadow prices of family labor were different from the observed wage rates.

\subsection{Swidden Rice Cultivation}

The average profit of all 20 swidden-rice cultivation was negative or zero, which indicated that swidden-rice cultivation was not profitable (table 24). In the study area, the practiced of swidden rice cultivation has declined over the year. However, swidden- rice cultivation was still important livelihood because of the importance of rice for food security. It was still attractive for some villagers since the return to family labor (income) was positive (IDR 24 038), although it was lower than the daily wage for agriculture (IDR 30 000.- per days). This finding was similar to the finding on the profitability of swidden rice cultivation in Sumatra (Suyanto et al 2001).

The swidden cultivation was very labor extensive, especially family labor, with less of using current capital. Labor cost take account $90 \%$ of total cost and the use of current input such as fertilizer and seed was very low. Fertilizer and pesticide applied $25 \%$ of plots and total cost of these current inputs was only $10 \%$ of total cost.

Labor use per hectare of swidden rice cultivation by activity and gender is shown in Table 25 . Several important observations can be made. First, labor use per hectare was low (63.4 person-days). Second, the proportion of female labor was about one-third, implying that both men worked more in swidden rice cultivation. There was, however, women worked primarily in harvesting, whereas men were engaged mostly in land preparation. The proportion of hired labor was very low (4.5\%) and exchange labor was $8.6 \%$ from total labor, which indicates that the labor market is not well developed in this area. 
Table 24. Gross revenue, production cost, residual Profit and Income of swidden-rice cultivation

\begin{tabular}{|l|r|}
\hline Total Cost (IDR) & $\mathbf{2 , 0 8 9 , 5 9 8}$ \\
\hline - Labor Cost (\%) & $\mathbf{9 0 \%}$ \\
\hline - Current Input (\%) & $\mathbf{1 0 \%}$ \\
\hline Gross Revenue (IDR) & $1,476,489$ \\
\hline Residual Profit (IDR) & $(613,109)$ \\
\hline Income (IDR) & $1,322,096$ \\
\hline Return to Family labor (IDR/person day) & 24,038 \\
\hline
\end{tabular}


Table 25. Labor use per ha for Paddy shifting cultivation by activities and gender

Activities
LABOR

\begin{tabular}{|c|c|c|c|c|c|c|c|c|c|c|c|c|}
\hline & \multicolumn{3}{|c|}{ Family labor } & \multicolumn{3}{|c|}{ Exchange labor } & \multicolumn{3}{|c|}{ Hire Labor } & \multicolumn{3}{|c|}{ Total } \\
\hline & $\begin{array}{c}\text { Men } \\
(\%)\end{array}$ & $\begin{array}{c}\text { Women } \\
(\%)\end{array}$ & $\begin{array}{c}\text { Person } \\
\text { working } \\
\text { day }\end{array}$ & $\begin{array}{c}\text { Men } \\
(\%)\end{array}$ & $\begin{array}{c}\text { Women } \\
\text { (\%) }\end{array}$ & $\begin{array}{c}\text { Person } \\
\text { Working } \\
\text { day }\end{array}$ & $\begin{array}{c}\text { Men } \\
(\%)\end{array}$ & $\begin{array}{c}\text { Women } \\
(\%)\end{array}$ & $\begin{array}{c}\text { Person } \\
\text { Working } \\
\text { day }\end{array}$ & $\begin{array}{c}\text { Men } \\
\text { (\%) }\end{array}$ & $\begin{array}{c}\text { Women } \\
(\%)\end{array}$ & $\begin{array}{c}\text { Person } \\
\text { Working } \\
\text { day }\end{array}$ \\
\hline Land preparation & 29.7 & 7.7 & 23.7 & 0.0 & 0.0 & 0.0 & 0.8 & 0.0 & 0.5 & 30.5 & 7.7 & 24.2 \\
\hline Planting & 3.7 & 1.9 & 3.5 & 3.6 & 2.9 & 4.1 & 0.7 & 1.4 & 1.3 & 8.0 & 6.1 & 9.0 \\
\hline Crop care & 10.4 & 3.9 & 9.1 & 0.0 & 0.0 & 0.0 & 0.0 & 0.8 & 0.5 & 10.4 & 4.7 & 9.6 \\
\hline Harvesting & 15.9 & 11.5 & 17.4 & 1.2 & 0.9 & 1.3 & 0.4 & 0.4 & 0.5 & 17.5 & 12.8 & 19.2 \\
\hline Post Harvesting & 1.7 & 0.6 & 1.4 & 0.0 & 0.0 & 0.0 & 0.0 & 0.0 & 0.0 & 1.7 & 0.6 & 1.4 \\
\hline Total & 61.4 & 25.6 & 55.1 & 4.8 & 3.8 & 5.4 & 1.9 & 2.6 & 2.8 & 68.0 & 32.0 & 63.4 \\
\hline
\end{tabular}




\subsection{Smallholder Rubber Plantation}

The sampled households had 115 plots of rubber plantations, of which 82 plots hectares were immature (tree aged below 10 years), 35 were mature and 8 were unproductive. The analysis undertaken in this report has excluded the unproductive rubber plantations.

Labor requirements of rubber production change dramatically as trees mature. Table 26 presents the statistics on labor use per hectare by activity, gender, and age of rubber trees compared. Several observations can be made. First, labor by men predominates in most rubber production activities. Second, labor used change over the years. Labor used was high in the first year; then they decline for several years when trees are immature. Labor used rise again when trees are old enough to be tapped with increases in harvesting labor. Third, family labor was very predominant in rubber production. The hire labor was almost none. High requirement of labor for establishment of rubber garden in the first year was fulfill by exchange labor among the community. The cost of family labor was imputed using the wage rate in this study area (IDR 30 000). Then we calculated the actual wage payments for hired labor, and actual costs of current inputs (seeds, seedlings, and chemical inputs for latex coagulation). Then we estimated actual paid-out costs and total production costs including the imputed costs of family labor. The average price of slab was IDR 3455 per $\mathrm{kg}$. The yield per hectare was $1926 \mathrm{~kg}$ (slab).

The total cost in the first year was high as a cost for establishment, in which consist of $61 \%$ of labor cost and 39\% of current input cost. The total cost has decline during the immature period. Then it was inclined again in the mature period. Profit was negative for the first ten years. Most trees, if not all, began to produce latex in the teen year, and consequently both the profit, as well as income, turns positive. The profit per hectare was IDR 3.3 million and income per hectare was IDR 6.4 million.

Since rubber trees are established and managed primarily by family labor, the income from mature trees was high close to the total revenue. Income or return to family labor for mature trees was IDR 65365 , in which higher than the wage rate for agriculture in this site (table 27). 
Table 26. Labor used per hectare of smallholder rubber by activities and age of trees in study site

\begin{tabular}{|c|c|c|c|}
\hline \multirow[t]{2}{*}{ ACTIVITIES } & \multicolumn{3}{|c|}{ Age of Trees } \\
\hline & 1 Year & 2-10 Year & $>10$ Year \\
\hline \multicolumn{4}{|l|}{ Land Preparation } \\
\hline Person working day & 12.03 & 0 & 0 \\
\hline - Man (\%) & 98 & 0 & 0 \\
\hline - Woman (\%) & 2 & 0 & 0 \\
\hline - Family labor (\%) & 79 & 0 & 0 \\
\hline - Exchange labor (\%) & 21 & 0 & 0 \\
\hline - Hire labor (\%) & 0 & 0 & 0 \\
\hline \multicolumn{4}{|l|}{ Planting } \\
\hline Person working day & 16.2 & 0.6 & 0 \\
\hline - Man (\%) & 84 & 83 & 0 \\
\hline - Woman (\%) & 16 & 17 & 0 \\
\hline - Family labor (\%) & 95 & 100 & 0 \\
\hline - Exchange labor (\%) & 5 & 0 & 0 \\
\hline - Hire labor (\%) & 0 & 0 & 0 \\
\hline \multicolumn{4}{|l|}{ Crop Care } \\
\hline Person working day & 23.51 & 25.2 & 6.8 \\
\hline - Man (\%) & 100 & 93 & 85 \\
\hline - Woman (\%) & 0 & 7 & 15 \\
\hline - Family labor (\%) & 55 & 84 & 100 \\
\hline - Exchange labor (\%) & 45 & 16 & 0 \\
\hline - Hire labor (\%) & 0 & 0 & 0 \\
\hline \multicolumn{4}{|l|}{ Harvesting } \\
\hline Person working day & 0 & 0 & 92.6 \\
\hline - Man (\%) & 0 & 0 & 78 \\
\hline - Woman (\%) & 0 & 0 & 22 \\
\hline - Family labor (\%) & 0 & 0 & 98 \\
\hline - Exchange labor (\%) & 0 & 0 & 0 \\
\hline - Hire labor (\%) & 0 & 0 & 2 \\
\hline \multicolumn{4}{|l|}{ Total } \\
\hline Person working day & 51.74 & 25.8 & 99.4 \\
\hline - Man (\%) & 95 & 93 & 78 \\
\hline - Woman (\%) & 5 & 7 & 22 \\
\hline - Family labor (\%) & 73 & 84 & 98 \\
\hline - Exchange labor (\%) & 27 & 6 & 0 \\
\hline - Hire labor (\%) & 0 & 0 & 2 \\
\hline
\end{tabular}


Table 27. Gross Revenue, Production Cost, Profit and income of Smallholder Rubber in Study Site

\begin{tabular}{|c|c|c|c|}
\hline & \multicolumn{3}{|c|}{ Age of Trees } \\
\hline & $<1$ Year & 1-10 Year & $>10$ Year \\
\hline Total Cost (Rupiah) & $2,528,062$ & 801,628 & $3,353,464$ \\
\hline - Labor Cost (\%) & 61 & 94 & 91 \\
\hline - Current Input (\%) & 39 & 6 & 9 \\
\hline Gross Revenue (Rupiah) & - & - & $6,656,874$ \\
\hline Residual Profit (Rupiah) & $(2,528,062)$ & $(913,427)$ & $3,303,410$ \\
\hline Income (Rupiah) & $(975,701)$ & $(40,856)$ & $6,367,353$ \\
\hline Income per Family Labor & & & 65,365 \\
\hline
\end{tabular}

\subsection{Opportunity Cost of Emission Reduction based on Profitability of Smallholder Rubber on Peat Land}

If peat lands are managed to minimize emissions, the direct costs (and benefits) of interventions such as blocking of canals and drains are accompanied by 'opportunity costs' of foregone or reduced agricultural production. Voluntary participation by land managers in schemes to reduce emissions require benefits beyond 'offset' for the opportunity cost of foregone peat land use. From an economic perspective, the costs of alternative ('sustainable') peat land management thus include the profitability of the (legal) agricultural production systems with the highest benefit (expressed as returns to land and/or labour). In the target KFCP area, this probably is smallholder rubber production.

Based on 107 plots of smallholder rubber from the baseline survey, we calculated the profitability in relation to age of trees as:

$$
\text { Profit }=\alpha+\beta_{1} \text { Age of trees }+\beta_{2} \text { Age of trees }{ }^{2}+\varepsilon
$$


Table 28. Regression of profit function of smallholder rubber in KFCP site

\begin{tabular}{|c|c|c|}
\hline & \multicolumn{2}{|c|}{ Profit (IDR 000) } \\
\hline & Coef & Std. Err \\
\hline$\alpha$ Constanta & $-2,350$ & 382,2 \\
\hline$\beta_{1}$ effect of age of Trees & $388,7^{* * *}$ & 51,4 \\
\hline$B_{2}$ effect of age of Trees ${ }^{2}$ & $-5,8 * * *$ & 1.1 \\
\hline $\mathrm{R}^{2}(\%)$ & 42 & \\
\hline $\mathrm{N}$ & 107 & \\
\hline Max Age of Trees (year) & 33 & \\
\hline
\end{tabular}

Note: *** significantly different from 'no effect' at $1 \%$ level

Judging from the regression coefficients, the peak of profitability is reached at a tree age of 33 years. If plantations are renewed at that age, life-cycle profitability (economic efficiency) is highest. For further analysis, we calculated the net present value of smallholder rubber over a 30 year production cycle, with an annual discount rate of $11 \%$.

Table 29. Opportunity Cost of smallholder rubber in 2009

\begin{tabular}{|l|l|l|}
\hline & Unit & Value \\
\hline $\begin{array}{l}\text { Net Present Value (NPV) per ha for } 30 \text { year } \\
\text { (discounted) }\end{array}$ & USD \$ /ha & 842 \\
\hline $\begin{array}{l}\mathrm{CO}_{2} \text { emitted due to shallow peatland drainage for } 30 \\
\text { year }\end{array}$ & Ton / ha & 810 \\
\hline $\begin{array}{l}\text { Opportunity cost (discounted) of avoiding } \mathrm{CO}_{2} \\
\text { emission }\end{array}$ & $\begin{array}{l}\text { USD \$/ t } \\
\mathrm{CO}_{2}\end{array}$ & 1.04 \\
\hline
\end{tabular}

Note: exchange rate in June 2009 was USD \$ 1=IDR 10215

The opportunity cost of smallholder rubber production relative to the emissions caused was USD \$ 1.04 per ton $\mathrm{CO}_{2}$ emitted. This opportunity cost of smallholder rubber can be interpreted as the cost or the price of avoiding one ton $\mathrm{CO}_{2}$ emission by not planting rubber and associated shallow drainage of the peat.

Revenue from carbon credits will be an attractive alternative from an economic perspective if it is higher than the opportunity cost plus transaction cost. The transaction costs include all administrative costs needed for the project from the start of the project idea until the handover of the credits. These include costs of the preparation of the project design document, the establishment of the monitoring strategy, monitoring and verification by independent third parties and the costs of the guidance of the validation and certification process are referred to as transaction costs. 
The comparison of opportunity costs of smallholder rubber with carbon markets depends on the mode of payment. The revenue may vary significantly if payment is done upfront, every year or at the end of the project. Table provides the real carbon price if the current price of carbon is USD \$ 5 and the duration of the project is 30 years.

Table 30. Real carbon prices

\begin{tabular}{|l|l|l|}
\hline Mode of Payment & $\begin{array}{l}\text { Real Price of Carbon per ton } \\
\mathrm{CO}_{2}\end{array}$ & $\begin{array}{l}\text { Ratio of payments to } \\
\text { opportunity costs }\end{array}$ \\
\hline Payment up front & 5.0 & 4.8 \\
\hline $\begin{array}{l}\text { Payment on a yearly basis } \\
\text { (discounted by 11\%) }\end{array}$ & 1.45 & 1.4 \\
\hline $\begin{array}{l}\text { Payment at end of the } \\
\text { project (discounted by 11\%) }\end{array}$ & 0.25 & 0.24 \\
\hline
\end{tabular}

Up-front payment: Without taking account of the transaction costs of carbon projects, if the mode of payment is up front, the price of carbon USD $\$ 5$ per ton $\mathrm{CO}_{2}$ is very attractive compared to the profitability of smallholder rubber.

Payment on a yearly basis: If the current carbon price is USD $\$ 5$ per ton $\mathrm{CO}_{2}$, the real price of carbon, assuming payment on a yearly basis, is USD $\$ 1.45$ per ton $\mathrm{CO}_{2}$. The carbon price is higher than the profit of smallholder rubber (USD $\$ 1.04$ per ton $\mathrm{CO}_{2}$ ), but there may be valid concerns over the long-term implementation of such payments.

Payment is at the end of the project: The carbon market is not attractive since the real price of carbon is lower than the opportunity cost of smallholder rubber.

In this analysis we used the carbon emitted from smallholder rubber on peatland is 27 ton $\mathrm{CO}_{2} /$ ha/year (Fahmudin Agus et al 2008). However, a recent study in peatlands in Aceh by a $\mathrm{PhD}$ candidate at IPB casted doubt on the current estimates that relate emissions directly to drainage depth $\left(1 \mathrm{t} \mathrm{CO} 2 / \mathrm{ha} / \mathrm{yr}\right.$ per $\mathrm{cm}$ of drain depth). If both methane and $\mathrm{CO}_{2}$ emissions are taken into account, any drainage (even that in affected peatland forest) probably is a cause of high emissions. For the AUSAID project the start of serious measurements in this area can no longer be postponed.

\subsection{Gemor extraction}

In the past, big trees of gemor with a diameter of around $90 \mathrm{~cm}$ were available in the forest, producing around 5-7 quintal ( 1 quintal $=100 \mathrm{~kg})$ of dry bark. Now, gemor trees are limited to a diameter of around $5-15 \mathrm{~cm}$ that produces only around $10-20 \mathrm{~kg}$ of dry bark.

Every villager had free access to harvest gemor in the forest. No local ownership existed for gemor trees. Farmers usually went to the forest for 7-14 days to harvest the bark. Non-labor cost approximately IDR 525 000/person for food, levy to enter tatah and gasoline for 13 person-days in the forest. In one trip a farmer could harvest $430 \mathrm{~kg}$ of gemor bark. The current price for dry gemor in study site was IDR $4000 \mathrm{Kg}^{-1}$. The price for dry gemor in area close to palangkalaraya was $6500 / \mathrm{kg}$ (Kompas, July 13,2009). The return to labor was high 
(IDR 89 179). It was higher than the daily wage for agriculture (IDR 30 000), even it was higher than the return to labor for smallholder rubber (IDR 65 365) (table 28).

However, villagers did not feel confident about the future of gemor harvesting. This was based on the difficulties they encountered when carrying out gemor harvesting in the forest, such as:

(i) Trees were increasingly farther away from their settlements and more difficult to reach.

(ii) Gemor trees were difficult to find and those that they could find were small. Farmers would harvest gemor of any size, thus there was no chance for a tree to reach a large diameter.

(iv) High competition, as more and more farmers were embarking on gemor harvesting.

(v) Forest fire and over harvesting threatened the growth of gemor trees.

Table 31. Revenue, cost and return to labor of gemor collection

\begin{tabular}{|l|r|}
\hline Total Gemor collection (Kg dry Bark) & 430 \\
\hline Price (IDR Kg ${ }^{-1}$ ) & 4,000 \\
\hline Revenue (IDR) & $1,720,000$ \\
\hline Cost (IDR) & 525,000 \\
\hline Levy to enter tatah (IDR) & 108,333 \\
\hline Meal (IDR) & 316,667 \\
\hline Gasoline (IDR) & 100,000 \\
\hline Income (IDR) & $1,195,000$ \\
\hline Labor use (person-day) & 13.4 \\
\hline Return to labor (IDR) & 89,179 \\
\hline
\end{tabular}




\section{Role of fire in the livelihoods of villagers}

\subsection{Fire in peat soils}

Fire in peat soils has recurred frequently in Block A since 1997, when the peat areas were opened up for the Mega Rice Project. According to the local people, forest and agricultural land on peat soils that existed in the village vicinity, were very susceptible to fire during the long dry season. In 1997, a fire that started in the forest and on abandoned land spread and ravaged the productive rubber systems owned by villagers in Block $\mathrm{A}$, causing great economic loss. A similar event occurred in 2005/2006 in Block E. In addition to economic loss, fires also caused smoke haze that hampered village activities and affected people's health (particularly eye and respiratory problems, including breathing difficulties and coughing). Smoke haze also affected transportation systems due to limited visibility that increased the risk of accidents.

However, according to the locals, preventing or tackling fires was very difficult. When fire events occurred, the locals prevented the fire from spreading to their land by creating an open area/ditch $1.8 \mathrm{~m}$ wide around their land to act as a firebreak. The ditch was meant to be deep enough so that ground water seepage surfaced. If the fire managed to spread onto their land, they tried to put out the fire using tree branches or water (in buckets). These efforts often failed as there were insufficient villagers to prevent the fire spreading, let alone extinguish it.

In most villages, local regulations regarding fire only had sanctions applying when the use of fire spread to neighboring land. However, Desa Katunjung had begun to develop Village Regulations $($ PERDES $=$ Peraturan Desa $)$, but they had not yet been implemented as they were waiting on approval from the Kabupaten level. In some villages, such as Mantangai Hulu, Kalumpang, Sei Ahas, and Katunjung, fire teams (Regu Pemadam Kebakaran = RPK) or community groups for fire management (Kelompok Masyarakat Pengendali Kebakaran = $\mathrm{KMPK}^{5}$ ) had already been established. In these villages the community/villagers had been urged to inform the RPK, village head and local authorities when they planned to open up land by the use of fire.

Table 29 and 30 show details of fire events that have occurred in peat soils in Blocks A and E.

\footnotetext{
${ }^{5}$ Several RPKs (Regu Pemadam Kebakaran = Fire Extinguishing Team ) were formed in cooperation with the CARE organization. An RPK consisted of a team of 15-21 people who had been trained in fire prevention and management, including how to put out a fire. Each team had one spray unit. The KMPK (Kelompok Masyarakat Pengendali Kebakaran Hutan = Community Group for Forest Fire Management) had a similar function to an RPK. KMPK were formed by the government with 9-10 people in one team. Each one also had one spray unit.
} 
Table 32. Large-scale fire events in peat soils in Block A.

\begin{tabular}{|c|c|c|c|c|c|}
\hline $\begin{array}{l}\text { Village/ } \\
\text { Hamlet }\end{array}$ & Year & Burned areas & Causal factors & $\begin{array}{l}\text { Impact (Problems } \\
\text { caused) }\end{array}$ & Fire control \\
\hline $\begin{array}{l}\text { Mantangai } \\
\text { Hulu }\end{array}$ & 1997 & $\begin{array}{l}\text { Rubber Garden, } \\
\text { Grasses and } \\
\text { Bush Fallow, } \\
\text { Dryland } \\
\text { Agricultural } \\
\text { Areas, Forest }\end{array}$ & Anthropogenic ${ }^{6}$ & $\begin{array}{l}\text { Health } \\
\text { Transportation } \\
\text { Working problems } \\
\text { Partial loss of } \\
\text { rubber garden }\end{array}$ & None \\
\hline Kalumpang & 1997 & $\begin{array}{l}\text { Rubber Garden, } \\
\text { Grasses and } \\
\text { Bush Fallow, } \\
\text { Dryland } \\
\text { Agricultural } \\
\text { Areas }\end{array}$ & Anthropogenic & $\begin{array}{l}\text { Health } \\
\text { Transportation } \\
\text { Working problems } \\
\text { Several rubber } \\
\text { gardens destroyed }\end{array}$ & None \\
\hline Sei Ahas & $\begin{array}{l}1997, \\
2006\end{array}$ & $\begin{array}{l}\text { Rubber Garden, } \\
\text { Grasses and } \\
\text { Bush Fallow, } \\
\text { Forest }\end{array}$ & Anthropogenic & $\begin{array}{l}\text { Health } \\
\text { Transportation } \\
\text { Working problems } \\
\text { Several rubber } \\
\text { gardens destroyed }\end{array}$ & None \\
\hline Katunjung & 1997 & $\begin{array}{l}\text { Rubber Garden, } \\
\text { Grasses and } \\
\text { Bush Fallow, } \\
\text { Forest }\end{array}$ & Anthropogenic & $\begin{array}{l}\text { Health } \\
\text { Transportation } \\
\text { Working problems } \\
\text { Several rubber } \\
\text { gardens destroyed }\end{array}$ & $\begin{array}{l}\text { Villagers put } \\
\text { out fire using } \\
\text { buckets }\end{array}$ \\
\hline
\end{tabular}

Table 33. Large-scale fire events in peat soils in Block E.

\begin{tabular}{|l|l|l|l|l|l|}
\hline Village/Hamlet & Year & $\begin{array}{l}\text { Burned } \\
\text { areas }\end{array}$ & Causal factors & \multicolumn{1}{|c|}{ Impact } & \multicolumn{1}{|c|}{$\begin{array}{c}\text { Fire } \\
\text { control }\end{array}$} \\
\hline Tanjung Kalanis & 2006 & $\begin{array}{l}\text { Rubber } \\
\text { Garden, } \\
\text { Grasses and } \\
\text { Bush } \\
\text { Fallow, } \\
\text { Forest }\end{array}$ & Anthropogenic & $\begin{array}{l}\text { Health } \\
\text { Transportation } \\
\text { Work problems } \\
\text { Several rubber } \\
\text { gardens destroyed }\end{array}$ & None \\
\hline Tumbang Muroi & 2005 & Forest & Natural causes & & None \\
\hline Kanjarau & 2002 & Forest & Anthropogenic & $\begin{array}{l}\text { Health } \\
\text { Transportation } \\
\text { Work problems }\end{array}$ & $\begin{array}{l}\text { Health } \\
\text { Transportation } \\
\text { Work problems }\end{array}$ \\
\hline Petak Puti & 2005 & Forest & Anthropogenic & $\begin{array}{l}\text { Health } \\
\text { Transportation } \\
\text { Work problems }\end{array}$ & None \\
\hline
\end{tabular}

$6 \quad$ It was suspected that the fire was caused by the carelessness of unidentified people, such as throwing away un-stubbed cigarettes, the uncontrolled opening up of land and the use of fire for fishing.

${ }^{7}$ According to villagers, during the dry season, the friction from dry tree branches moving in the wind started fires. 


\subsection{Fire on mineral soils}

In Block A, most fire events occurring on mineral soils originated from fires spreading from peat soils. In Block E, all fire events were anthropogenic, except in Desa Petak Puti where a fire was not anthropogenically caused (table 32 and 33). In mineral soils, fire events rarely occurred, as farmers usually had these areas under intensive management for agriculture and they practiced careful use of fire for opening up their land including the use of fire corridors and guards during land opening operations.

As with fires in peat soils, fires in mineral soils also affected the health and working activities of the villagers as well as transportation in the area. Some farmers also had lost their rubber gardens through such fires. No specific fire management activity was practiced. Farmers did their best to prevent fires from spreading by building fire corridors around burning areas and building wells as sources of water to extinguish the fire.

Table 34. Fire events in mineral soils in Block A.

\begin{tabular}{|c|c|c|c|c|c|}
\hline $\begin{array}{c}\text { Village / } \\
\text { Hamlet }\end{array}$ & Year & Burned areas & $\begin{array}{l}\text { Causal } \\
\text { factors }\end{array}$ & Impact & Fire control \\
\hline $\begin{array}{l}\text { Mantangai } \\
\text { Hulu }\end{array}$ & 1997 & $\begin{array}{l}\text { Rubber Garden, } \\
\text { Grasses And } \\
\text { Bush Fallow, } \\
\text { Dryland } \\
\text { Agriculture } \\
\text { Areas }\end{array}$ & $\begin{array}{l}\text { Spreading } \\
\text { from fire in } \\
\text { peat soils }\end{array}$ & $\begin{array}{l}\text { Several rubber } \\
\text { gardens destroyed } \\
\text { Health problems } \\
\text { Transportation } \\
\text { problems } \\
\text { Work problems }\end{array}$ & None \\
\hline Kalumpang & 1997 & $\begin{array}{l}\text { Rubber Garden, } \\
\text { Grasses and } \\
\text { Bush Fallow, } \\
\text { Dryland } \\
\text { Agriculture } \\
\text { Areas }\end{array}$ & $\begin{array}{l}\text { Spreading } \\
\text { from fire in } \\
\text { peat soils }\end{array}$ & $\begin{array}{l}\text { Several rubber } \\
\text { gardens destroyed } \\
\text { Health problems } \\
\text { Transportation } \\
\text { problems } \\
\text { Work problems }\end{array}$ & None \\
\hline Sei Ahas & $\begin{array}{l}\text { 1997, } \\
2006\end{array}$ & $\begin{array}{l}\text { Rubber Garden, } \\
\text { Grasses and } \\
\text { Bush Fallow }\end{array}$ & $\begin{array}{l}\text { Spreading } \\
\text { from fire in } \\
\text { peat soils }\end{array}$ & $\begin{array}{l}\text { Several rubber } \\
\text { gardens destroyed } \\
\text { Health problems } \\
\text { Transportation } \\
\text { problems } \\
\text { Work problems }\end{array}$ & None \\
\hline Katunjung & 2007 & $\begin{array}{l}\text { Rubber Garden, } \\
\text { Grasses and } \\
\text { Bush Fallow, } \\
\text { Dryland } \\
\text { Agriculture } \\
\text { Areas }\end{array}$ & $\begin{array}{l}\text { Spreading } \\
\text { from fire in } \\
\text { peat soils }\end{array}$ & $\begin{array}{l}\text { Several rubber } \\
\text { gardens destroyed } \\
\text { Health problems } \\
\text { Transportation } \\
\text { problems } \\
\text { Work problems }\end{array}$ & $\begin{array}{l}\text { Villagers put } \\
\text { out fire using } \\
\text { buckets }\end{array}$ \\
\hline
\end{tabular}


Table 35. Fire events in mineral soils if Block E.

\begin{tabular}{|c|c|c|c|c|c|}
\hline $\begin{array}{c}\text { Village / } \\
\text { Hamlet }\end{array}$ & Year & $\begin{array}{c}\text { Burned } \\
\text { areas }\end{array}$ & Causal factors & Impact & Fire control \\
\hline $\begin{array}{l}\text { Tanjung } \\
\text { Kalanis }\end{array}$ & $\left.2007^{*}\right)$ & $\begin{array}{l}\text { Rubber } \\
\text { Garden, } \\
\text { Grasses and } \\
\text { Bush Fallow }\end{array}$ & Anthropogenic & $\begin{array}{l}\text { Several rubber } \\
\text { gardens } \\
\text { destroyed }\end{array}$ & None \\
\hline $\begin{array}{l}\text { Tumbang } \\
\text { Muroi }\end{array}$ & $2005^{*}$ & $\begin{array}{l}\text { Rubber } \\
\text { And Rattan } \\
\text { Garden, } \\
\text { Grasses and } \\
\text { Bush Fallow }\end{array}$ & Anthropogenic & $\begin{array}{l}\text { Several rubber } \\
\text { gardens } \\
\text { destroyed }\end{array}$ & $\begin{array}{l}\text { Villagers } \\
\text { tried to put } \\
\text { out fire }\end{array}$ \\
\hline Kanjarau & 2007 & $\begin{array}{l}\text { Rubber } \\
\text { And Rayyan } \\
\text { Garden, } \\
\text { Grasses and } \\
\text { Bush Fallow }\end{array}$ & Anthropogenic & $\begin{array}{l}\text { Several rubber } \\
\text { and rattan } \\
\text { gardens } \\
\text { destroyed } \\
\text { Health problems } \\
\text { Transportation } \\
\text { problems } \\
\text { Work problems }\end{array}$ & None \\
\hline Petak Puti & 2005 & $\begin{array}{l}\text { Rubber } \\
\text { And Rattan } \\
\text { Garden, } \\
\text { Grasses and } \\
\text { Bush Fallow }\end{array}$ & $\begin{array}{l}\text { Spreading out } \\
\text { from fire on } \\
\text { peat soils }\end{array}$ & $\begin{array}{l}\text { Several rubber } \\
\text { and rattan } \\
\text { gardens } \\
\text { destroyed } \\
\text { Health problems } \\
\text { Transportation } \\
\text { problems } \\
\text { Work problems }\end{array}$ & \\
\hline
\end{tabular}

\subsection{Regulations for the use of fire in land clearing activities}

Villagers in Blocks $\mathrm{A}$ and $\mathrm{E}$ knew that there was a regulation on the use of fire for land clearing. However, their understanding of the regulation's contents varied. Some mentioned that the regulation prohibited the use of fire, while some others said that the regulation contained a procedure to obtain permission prior to land clearing. This lack of understanding showed that the land clearing regulations have not been successfully promulgated among villagers

Farmers were still using slash and burn techniques to open up their land. They said they did not know a cheaper or more practical way to open up land. They also felt that they did not need permission to do anything on their own land, except to inform their neighbors, so they could help in the activity and prevent the fire from spreading. Some farmers had tried to use slashing only, without burning, but the trees failed to grow and required more fertilizer.

In managing fire, farmers followed traditional rules/local laws inherited from their elders on sanctions/penalties when the fire spread to neighbouring land. Penalties differed between villages, but there was a common procedure to calculate the amount. The main factor 
considered was rubber trees; their age, the price of latex and the number of years the rubber trees would still have been productive. Based on these three components, a productive burnt rubber tree could cost from IDR 100000 up to IDR 150 000. If the rubber tree was still young (not yet productive), the penalty was based on the amount of investment (cost of planting and maintenance), with a cost of about IDR 50000 to IDR $75000 /$ tree. The penalty could also be based on the cost of a rubber garden. Information on past incidences suggested that the penalties had been based on a 'gentlemen's agreement', rather than on the the method in the regulation. In some cases, when the 'guilty' farmer was poor or still a member of a family, no sanction/penalty took place.

Farmers were divided in terms of their views towards government prohibition on the use of fire for land clearing. Some agreed, because fire could spread to other gardens and these were valuable assets and thus needed to be protected. Some were opposed, unless new, inexpensive, practical methods to clear land could be found that would fertilize the soils in similar way as the slash and burn method.

\subsection{Local participation in preventing and tackling fires}

Most villagers said they would help to put out a fire if it occurred on someone's land to prevent it from spreading to other areas. They also felt that helping others was a responsibility as a member of the community and being a part of the one big family. However, a few felt reluctant to help and get involved as they feared they would be blamed for starting the fire.

On the other hand, if the fire occurred in the forest, most villagers said they would not help to extinguish the fire. This was largely because the forest was often too far from the settlement, so it would be costly to get there using a boat (requiring gasoline for the engine) and time consuming (interrupting other daily activities). In addition to this, villagers also felt that even if they did help, they would not be able to put out a fire in the forest or grassland, as the fire would be too large to extinguish with their existing tools.

Villager participation in fire management was dependent on the distance from their settlement to the fire location. Moreover, since RPK and KMPK existed, villagers felt that the fire teams were more capable of extinguishing a fire because they had been trained to do so. In reality, the RPK and KMPK hardly functioned independently as they did not have any operational budget. At the time of the survey, the RPK and KMPK had only functioned when villagers sought their help to oversee land clearing where the villagers had covered their operational costs including buying gasoline.

\subsection{Local activities using fire}

There were three main uses of fire by locals: to open up dryland agricultural plots, to open up rubber plots and for fishing. Slash and burn activity to open up land normally took place at the end of dry season, so the plot was ready for planting at the start of the rainy season. Fishing also was often carried out during the dry season, at baruh/lutu' and luwau by burning plants and bushes. These three activities potentially could cause fire events. 


\section{The drainage system}

In the study areas, three types of man-made ditch were found that functioned as drainage systems: (i) canals, (ii) handil and (iii) tatah (table 34 and 35).

\section{(i) Canals}

Canals were found in the Mega Rice Project with four levels (primary, secondary, tertiary, and quaternary). The canals were established to drain water from peat areas so that the land could be cultivated. The existence of canals made it easier to manage the outflow of the water through a system of small reservoirs and water gates. Nowadays, on the ex Mega Rice Project areas, farmers have established rubber plantations, so they no longer use the canals as drainage systems, but rather as an effective transportation route to access their plantations. According to farmers, fire events had increased since the areas were opened up and canals were built. The establishment of canals had dried out the peat areas making them more prone to fire events.

\section{(ii) Handil}

A handil is a ditch that has been built voluntarily by locals as a drainage system in addition to providing transportation to support their agricultural activities (for annual crops as well as tree-based systems). Traditional use of handil as part as agricultural management was only found in the villlages of Block A that had been in existence since before 1970. According to the locals, the idea to establish handil arose when they could not find any more available land close to the river; all land had already been opened up and was owned by others. Consequently, farmers formed a group to establish handil so that they could open up land for cultivation that was far away from their settlement. Most handil were built from the end of $s a k a^{8}$ together (Handap hapakat) with prior agreement on land allotment based on the number of people in a group. Each handil group had a chairman who coordinated and organized agricultural activities (e.g. deciding on planting time and which types to plant) as well as the maintenance of the handil. The chairman was supported by a land chairman who was responsible for coordinating land allocation. The handil committee rotated through generations. One of the most important rules in the handil was that if one farmer stopped cultivating his land for three consecutive years, the land would be taken by the chairman and given to a new farmer who was willing to join the group with the approval of the other members.

\section{(iii) Tatah}

A Tatah is a ditch that originally functioned to connect the river with forest areas, making it easy to access timber in the forests. Recently, with the dimunition of timber harvesting in the forests, tatah have been used to access non-timber forest products such as gemor, rattan and damar resin.

The tradition of managing tatah started from the time when communities conducted logging activities, probably around 1960 for the communities in Block A and around 1980 for

\footnotetext{
${ }^{8} \mathrm{~A}$ saka is a river tributary with length less than $2.5 \mathrm{~km}$.
} 
communities in Block E. Tatah could be established by a group or individually. Tatah established by a group were owned communally by its members and levies earned from the use of the tatah were split evenly among members. A tatah that was established individually was usually built by hiring laborers. A tatah was generally $1 \mathrm{~m}$ wide, $1 \mathrm{~m}$ deep and could be more than $10 \mathrm{~km}$ long. Whoever transported non-timber forest products using a particular tatah had to pay a levy of $10 \%$ of the products. In some villages, the levy is IDR 25000 per quintal for gemor. To access forest, a person could open up a new branch of a tatah from an existing one after obtaining permission from its owner. A similar levy would apply when the new branch tatah owner passed the original tatah. If the new branch were no longer maintained or used, the owner of originating tatah could acquire it. Even though the tatah no longer function collectively as a drainage system, ecologically their existence alters the hydrological structure of the peat forest. Tatah will accelerate the drying out of peat soils during the dry season, making them more susceptible to forest fire. In this context, the tatah play an important role in the drainage system of peat soils. To access the peat forest, in shallow as well as deep peat, communities in Blocks A and E still use tatah. They provide an important transportation system for village communities to access forest resources (both timber and non-timber) on peat and mineral soils. Therefore, the communities opposed the blockage of tatah and demanded compensation if that happened. The community strongly felt that blockage of tatahs would result in the loss of their livelihood options to harvest nontimber forest products. Nevertheless, they could accept the construction of water gates and changes to make the tatahs into small reservoir systems, which the community could still use to access forest. Similarly, the community also opposed any program that planned to block any handil. According to locals, blockage of handils would cause difficulties in accessing their agricultural land and their land would be flooded, resulting in reduced crop production. Arguments against blocking canals are consistent with the findings by Vam Beukeing et al., 2008.

Table 36. Types and number of drainage systems in villages in Block A.

\begin{tabular}{|l|l|c|c|l|}
\hline \multicolumn{1}{|c|}{ Village } & Drainage type & Number & $\begin{array}{c}\text { Number of } \\
\text { blocked drains }\end{array}$ & \multicolumn{1}{|c|}{ Management systems } \\
\hline Mantangai Hulu & Canal & 23 & 2 & None \\
& Handil & 0 & 0 & Group \\
& Tatah & 2 & 0 & Individual \\
\hline Kalumpang & Canal & 15 & 1 & None \\
& Handil & 11 & 0 & Group \\
\hline Sei Ahas & Tatah & 15 & 0 & Individual and group \\
& Canal & 28 & 2 & None \\
\hline Katunjung & Handil & 2 & 0 & Personal \\
& Tatah & 50 & 0 & Personal \\
\hline & Canal & 9 & 6 & None \\
& Handil & 4 & 0 & Group \\
& Tatah & 8 & 0 & Individual \\
\hline
\end{tabular}


Table 37. Types and number of drainage systems in villages in Block E.

\begin{tabular}{|c|c|c|c|c|}
\hline Village & Drainage type & Number & $\begin{array}{c}\text { Number of } \\
\text { blocked drainage }\end{array}$ & Management systems \\
\hline \multirow[t]{3}{*}{ Tanjung Kalanis } & Canal & 0 & - & - \\
\hline & Handil & 0 & - & - \\
\hline & Tatah & 14 & 0 & Personal and group \\
\hline \multirow[t]{3}{*}{ Tumbang Muroi } & Canal & 0 & - & - \\
\hline & Handil & 0 & - & - \\
\hline & Tatah & 0 & - & - \\
\hline \multirow[t]{3}{*}{ Kanjarau } & Canal & 0 & - & - \\
\hline & Handil & 0 & - & - \\
\hline & Tatah & 0 & - & - \\
\hline \multirow[t]{3}{*}{ Petak Puti } & Canal & 0 & - & - \\
\hline & Handil & 0 & - & - \\
\hline & Tatah & 3 & 0 & Personal \\
\hline
\end{tabular}




\section{Opportunities and challenges for emission reduction}

Currently, the area is a source of large (although poorly quantified) $\mathrm{CO}_{2}$ emissions due to 1) accelerated decomposition of the peat after drainage and (locally) fertilization, 2) fire used for land clearing and periodically becoming a wildfire that is out of control. The fire risk is enhanced under dry conditions and drainage of the swamps thus affects both emission pathways: gradual oxidation and episodic fires. Combined the $\mathrm{C}$ losses on peat soils can be easily 10 times higher than from forests on mineral soils.

Emission reduction strategies therefore need to deal with the hydrological integrity of the peatdome and deal with drainage. The deep drainage channels of the mega-rice program need to be closed as a first step (ongoing efforts), as its impacts can reach across the dome as a whole. The more superficial drainage of handil and tatah type canals probably does not extend beyond the village scale, but reducing their local impacts is still a priority for emission reduction. As these canals provide a transport function that is important for local livelihoods as well as drain the peat, water management systems for the canals that allow transport but reduce drainage are needed. Avoiding dry conditions in the canals actually is important for the transport function as well as the objective of reducing drainage, so some new solutions may be found.

The area still contains considerable areas of forest that have been logged-over, are depleted in high-value timber species such as ramin and are used for gemor exploitation, but otherwise still retain important biodiversity (incl. Orang-utan, esp. In the areas closer to the river where nutrient supply from the river has supported fruit trees) and about half of the original forest $\mathrm{C}$ stock. Protecting the aboveground biomass in these forests and allowing forest regeneration will increase terrestrial $\mathrm{C}$ stock, just as it does on mineral soils.

A major challenge for effective emission reduction in the area is the need for an integrated approach across the peat dome, while the riparian edges of the dome are in the traditional sphere of influence of the villages and temporary settlements. They claim historic rights of used that are not respected in existing forest classification schemes. The RATA study provides further detail on these claims and the steps needed to make progress on the issue. Voluntary approaches to canal management are needed that recognize the opportunity costs for local livelihoods. Given the imporatance of fisheries in the local livelihoods, especially for the poorer households, interactions between canal management and fish production need to be considered. The levels of financial compensation needed to achieve canal management on an outcome-basis ("no new canals + modification of existing ones to reduce their drainage effects'), shall be a priority topic for REDD implementation in the area.

Beyond the drainage issue, landscape level management to control fires to reduce emissions also need attention, as the village institutions and scope for fire control are effective close by the village, but not further out in the landscape. Such efforts, beyond providing employment opportunities, will benefit the local livelihood systems as the smoke episodes are very unhealthy and may affect forest productivity (phenological data of the orang-utan research 
station suggest low levels of forest fruit production half a year after the last smoke/haze episode).

The initial ideas for the KFCP also include reforestation or tree planting in degraded peat area in block A, as third component beyond drainage reduction and fire control. The types of trees to be planted will need to take the livelihood strategies into account, as well the specific objectives of $\mathrm{C}$ storage. Tree $\mathrm{C}$ sequestration rates will be small relative to drainage and fire effects, so the interactions with those two processes can be important. Among the local tree resources, Gemor appears a logical candidate for planting and more intensive management. The study tree-based land use option will provide further analysis of this opportunity.

The livelihood data have revealed that a relatively large fraction of the population is poor and has few resources to invest and little opportunity to take risk. Villagers' response to initial canal blocking efforts have been negative and new options need to be discussed at local level and/or stimulated by outcome-based rules and incentives, rather than prescriptions of activities. 


\section{Appendix 1}

The Gini Index Formula

The Gini decomposition formula (Equation 1) was developed by Fei, Ranis, and Kuo (1978).

$$
\mathrm{G}(\mathrm{Y})=\Sigma \text { si } \mathrm{R}(\mathrm{Y}, \mathrm{Yi}) \mathrm{G}(\mathrm{Yi})
$$

where: $G(Y)=$ Gini ratio of total income,

$\mathrm{Yi}=$ income from the $i^{\text {th }}$ source of income,

$\mathrm{si}=$ share of the $\mathrm{i}^{\text {th }}$ source of income,

$\mathrm{R}(\mathrm{Y}, \mathrm{Yi})=$ the rank correlation ratio,

$\mathrm{G}(\mathrm{Yi})=$ Gini ratio of the $\mathrm{i}^{\text {th }}$ source of income .

$\mathrm{R}(\mathrm{Y}, \mathrm{Yi})$ is the rank correlation ratio expressed as Equation 2:

$\mathrm{R}(\mathrm{Y}, \mathrm{Yi})=\operatorname{Cov}\{\mathrm{Yi}, \mathrm{r}(\mathrm{Y})\} / \operatorname{Cov}\{\mathrm{Yi}, \mathrm{r}(\mathrm{Yi})\}$

where: $r(Y)=$ ranking of households in terms of total income,

$(\mathrm{Yi})=$ ranking of the $i^{\text {th }}$ source of income.

Moreover, Alderman and Gracia (1993) elucidated the decomposition of the Gini coefficient (Equation 3):

$$
\begin{aligned}
& \mathrm{gi}=\mathrm{R}(\mathrm{Y}, \mathrm{Yi}) \mathrm{G}(\mathrm{Yi})\} / \mathrm{G}(\mathrm{Y}) \\
& \sum \text { si gi }=1
\end{aligned}
$$

where: $g i=$ the relative concentration coefficient of the $i^{\text {th }}$ source in overall inequality.

To assess whether the $\mathrm{i}^{\text {th }}$ source of income is increasing-inequity or inequality-decreasing, we compare whether the relative concentration coefficient (gi) is greater or less than unity. 


\section{Appendix II}

Sketch map of Kalumpang village in block A

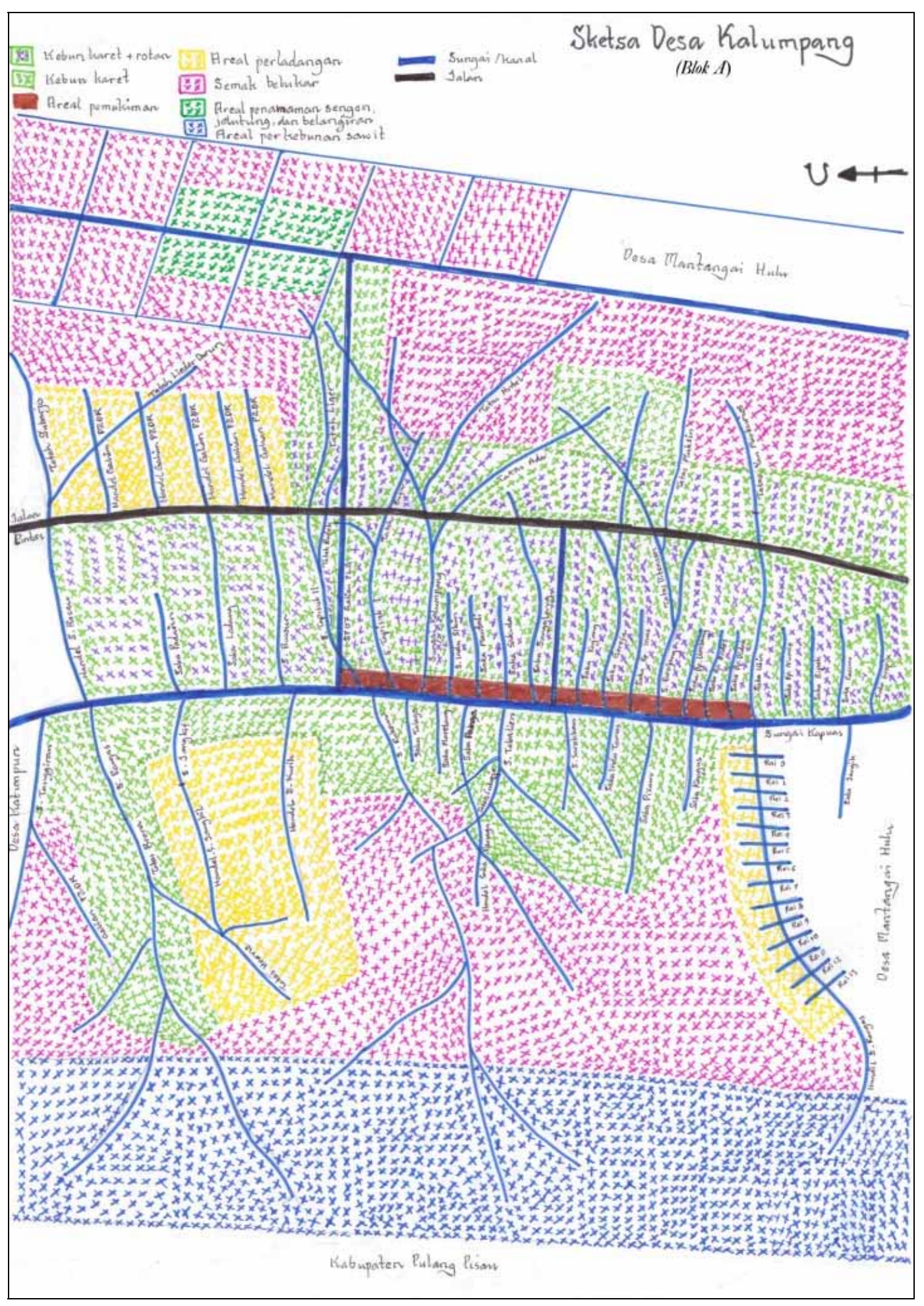




\section{Appendix III}

Sketch map of Tumbang Muroi village in block E

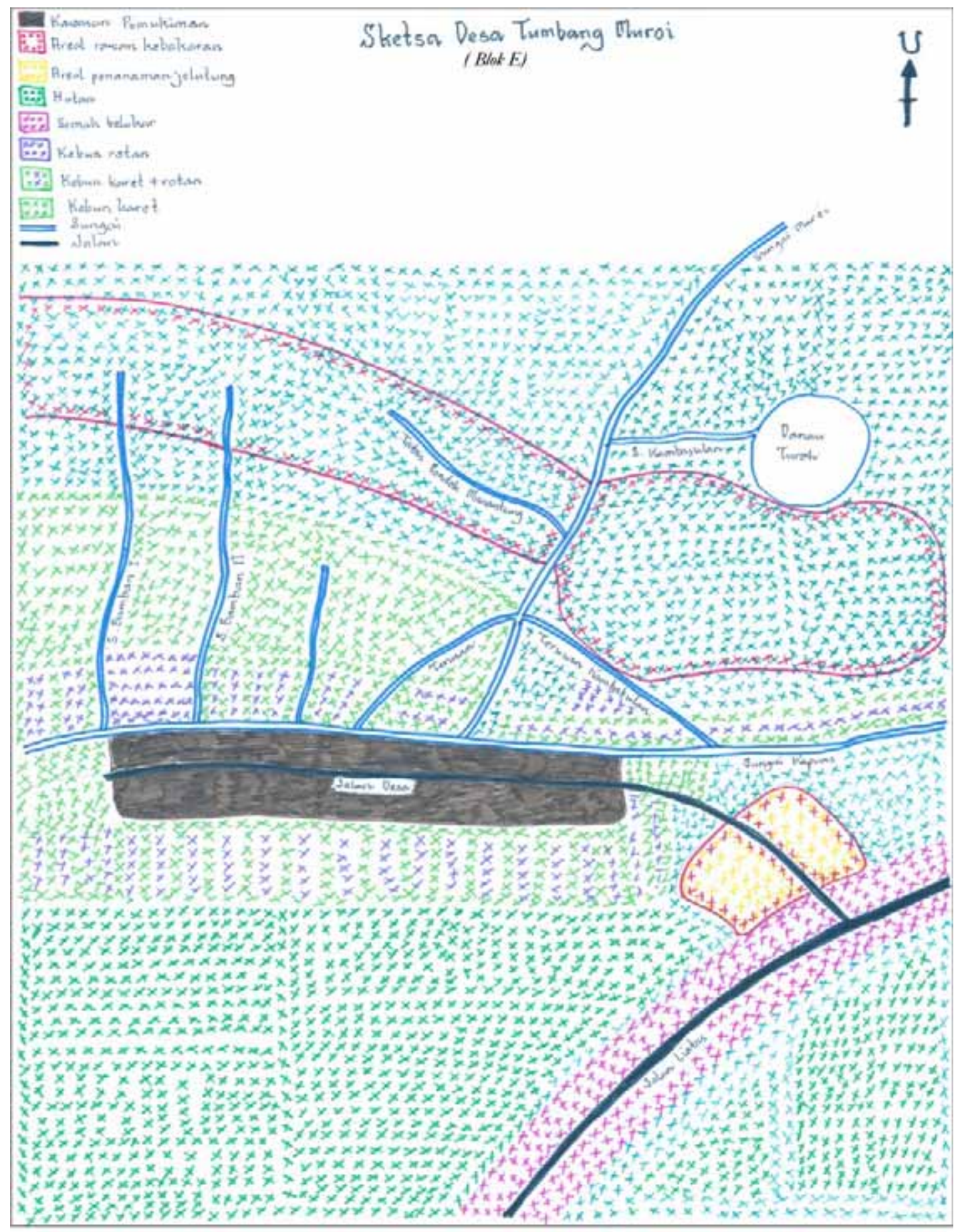




\section{References}

Agus, Fahmuddin., Wahyunto and Meine van Noordwijk. 2007. ASSUMPTIONS IN CARBON STOCKS AND CO2 EMISSIONS FROM PEATLAND. Power Point Presentation in one day seminar on "Avoided Deforestation and Carbon Emissions with Sustainable Benefits (ADSB) in Indonesia's Forest Mosaics and Peatlands" ICRAF, 20 November 2007.

Badan Pusat Statistik. 2008. Data dan Infromasi Kemiskinan Tahun 2007 Buku 1: provinsi. BPS Jakarta-Indonesia

Badan Pusat Statistik. 2008. Data dan Infromasi Kemiskinan Tahun 2007 Buku 2: Kabupaten/Kota. BPS Jakarta-Indonesia

Badan Pusat Statistik Kalimantan Tengah. 2009. http://kalteng.bps.go.id/

Barr, C. 2001. Banking on Sustainability: Structural Adjustment and Forestry Reform in PostSuharto Indonesia. Macroeconomics for Sustainable Development Program Office, WWF, Washington DC. 140pp.

de Jong, W. 1994. Recreating the Forest: Successful Examples of Ethno-Conservation among Land-Dayaks in Central West Kalimantan. In: International Symposium on Management of Tropical Forests in Southeast Asia, Oslo.

Dove, M. R. 1993. Smallholder Rubber and Swidden Agriculture in Borneo: A Sustainable Adaptation to The Ecology and Economy of The Tropical Forest. Economic Botany 47 (2):136-147.

Fei, J.C.H., G. Ranis and S.W.Y.Kuo. 1978. Growth and family distribution of income by factor component. Quarterly Journal of Economics 92:17-53.

Gouyan, Anne; de Foresta, Hubert, and Levang, Patrice. 1993. "Does Jungle Rubber Deserve its Name? An Analysis of Rubber Agroforestry Systems in Southeast Sumatra." Agroforestry Systems 22 (1993): 181-206.

Kompas. 2009. Hasil Hutan Marak, Pencarian Gemor Saat kemarau. 13 Juli 2009.

Suyanto S, Tomich TP and Otsuka K. 2001. Land tenure and farm management efficiency: the case of smallholder rubber production in customary land areas of Sumatra. Agroforestry Systems. 52(2):P. 145-160.

UNDP. 2009. Human Development Report 2007/2008 Indonesia. http://hdrstats.undp.org/countries/country_fact_sheets/cty_fs_IDN.html

Van Beukering P.J.H., Schaafsma M., Davies O. \& Oskolokaite I., 2008. The economic value of peatland resources within the Central Kalimantan Peatland Project in Indonesia. Palangkaraya, unpublished report

Van Noordwijk M, Elok Mulyoutami, Niken Sakuntaladewi, Fahmuddin Agus. 2008. Swiddens in Transition: Shifted Perceptions on Shifting Cultivators in Indonesia. ICRAF

Zulnely and Martono, D. 2003. The Possible Utilization of Gemor (Alseodaphne sp.) Bark as Material for the Manufacture of Anti Mosquito Agent. 


\section{WORKING PAPERS IN THIS SERIES}

\section{5}

1. Agroforestry in the drylands of eastern Africa: a call to action

2. Biodiversity conservation through agroforestry: managing tree species diversity within a network of community-based, nongovernmental, governmental and research organizations in western Kenya.

3. Invasion of prosopis juliflora and local livelihoods: Case study from the Lake Baringo area of Kenya

4. Leadership for change in farmers organizations: Training report: Ridar Hotel, Kampala, 29th March to 2nd April 2005.

5. Domestication des espèces agroforestières au Sahel : situation actuelle et perspectives

6. Relevé des données de biodiversité ligneuse: Manuel du projet biodiversité des parcs agroforestiers au Sahel

7. Improved land management in the Lake Victoria Basin: TransVic Project's draft report.

8. Livelihood capital, strategies and outcomes in the Taita hills of Kenya

9. Les espèces ligneuses et leurs usages: Les préférences des paysans dans le Cercle de Ségou, au Mali

10. La biodiversité des espèces ligneuses: Diversité arborée et unités de gestion du terroir dans le Cercle de Ségou, au Mali

11. Bird diversity and land use on the slopes of Mt. Kilimanjaro and the adjacent plains, Tanzania

12. Water, women and local social organization in the Western Kenya Highlands

13. Highlights of ongoing research of the World Agroforestry Centre in Indonesia

14. Prospects of adoption of tree-based systems in a rural landscape and its likely impacts on carbon stocks and farmers' welfare: The FALLOW Model Application in Muara Sungkai, Lampung, Sumatra, in a 'Clean Development Mechanism' context

15. Equipping integrated natural resource managers for healthy agroforestry landscapes.

16. Are they competing or compensating on farm? Status of indigenous and exotic tree species in a wide range of agro-ecological zones of Eastern and Central Kenya, surrounding Mt. Kenya.

17. Agro-biodiversity and CGIAR tree and forest science: approaches and examples from Sumatra.

18. Improving land management in eastern and southern Africa: A review of polices.

19. Farm and household economic study of Kecamatan Nanggung, Kabupaten Bogor, Indonesia: A socio-economic base line study of agroforestry innovations and livelihood enhancement.

20. Lessons from eastern Africa's unsustainable charcoal business.

21. Evolution of RELMA's approaches to land management: Lessons from two decades of research and development in eastern and southern Africa

22. Participatory watershed management: Lessons from RELMA's work with farmers in eastern Africa.

23. Strengthening farmers' organizations: The experience of RELMA and ULAMP. 
24. Promoting rainwater harvesting in eastern and southern Africa.

25. The role of livestock in integrated land management.

26. Status of carbon sequestration projects in Africa: Potential benefits and challenges to scaling up.

27. Social and Environmental Trade-Offs in Tree Species Selection: A Methodology for Identifying Niche Incompatibilities in Agroforestry [Appears as AHI Working Paper no. 9]

28. Managing tradeoffs in agroforestry: From conflict to collaboration in natural resource management. [Appears as AHI Working Paper no. 10]

29. Essai d'analyse de la prise en compte des systemes agroforestiers pa les legislations forestieres au Sahel: Cas du Burkina Faso, du Mali, du Niger et du Senegal.

30. Etat de la recherche agroforestière au Rwanda etude bibliographique, période 19872003

31. Science and technological innovations for improving soil fertility and management in Africa: A report for NEPAD's Science and Technology Forum.

32. Compensation and rewards for environmental services.

33. Latin American regional workshop report compensation.

34 Asia regional workshop on compensation ecosystem services.

35 Report of African regional workshop on compensation ecosystem services.

36 Exploring the inter-linkages among and between compensation and rewards for ecosystem services CRES and human well-being

37 Criteria and indicators for environmental service compensation and reward mechanisms: realistic, voluntary, conditional and pro-poor

38 The conditions for effective mechanisms of compensation and rewards for environmental services.

39 Organization and governance for fostering Pro-Poor Compensation for Environmental Services.

40 How important are different types of compensation and reward mechanisms shaping poverty and ecosystem services across Africa, Asia \& Latin America over the Next two decades?

41. Risk mitigation in contract farming: The case of poultry, cotton, woodfuel and cereals in East Africa.

42. The RELMA savings and credit experiences: Sowing the seed of sustainability

43. Yatich J., Policy and institutional context for NRM in Kenya: Challenges and opportunities for Landcare.

44. Nina-Nina Adoung Nasional di So! Field test of rapid land tenure assessment (RATA) in the Batang Toru Watershed, North Sumatera.

45. Is Hutan Tanaman Rakyat a new paradigm in community based tree planting in Indonesia?

46. Socio-Economic aspects of brackish water aquaculture (Tambak) production in Nanggroe Aceh Darrusalam.

47. Farmer livelihoods in the humid forest and moist savannah zones of Cameroon.

48. Domestication, genre et vulnérabilité : Participation des femmes, des Jeunes et des catégories les plus pauvres à la domestication des arbres agroforestiers au Cameroun. 
49. Land tenure and management in the districts around Mt Elgon: An assessment presented to the Mt Elgon ecosystem conservation programme.

50. The production and marketing of leaf meal from fodder shrubs in Tanga, Tanzania: A pro-poor enterprise for improving livestock productivity.

51. Buyers Perspective on Environmental Services (ES) and Commoditization as an approach to liberate ES markets in the Philippines.

52. Towards Towards community-driven conservation in southwest China: Reconciling state and local perceptions.

53. Biofuels in China: An Analysis of the Opportunities and Challenges of Jatropha curcas in Southwest China.

54. Jatropha curcas biodiesel production in Kenya: Economics and potential value chain development for smallholder farmers

55. Livelihoods and Forest Resources in Aceh and Nias for a Sustainable Forest Resource Management and Economic Progress.

56. Agroforestry on the interface of Orangutan Conservation and Sustainable Livelihoods in Batang Toru, North Sumatra.

57. Assessing Hydrological Situation of Kapuas Hulu Basin, Kapuas Hulu Regency, West Kalimantan.

58. Assessing the Hydrological Situation of Talau Watershed, Belu Regency, East Nusa Tenggara.

59. Kajian Kondisi Hidrologis DAS Talau, Kabupaten Belu, Nusa Tenggara Timur.

60. Kajian Kondisi Hidrologis DAS Kapuas Hulu, Kabupaten Kapuas Hulu, Kalimantan Barat.

61. Lessons learned from community capacity building activities to support agroforest as sustainable economic alternatives in Batang Toru orang utan habitat conservation program (Martini, Endri et al.)

62. Mainstreaming Climate Change in the Philippines.

63. A Conjoint Analysis of Farmer Preferences for Community Forestry Contracts in the Sumber Jaya Watershed, Indonesia.

64. The Highlands: A shower water tower in a changing climate and changing Asia.

65. Eco-Certification: Can It Deliver Conservation and Development in the Tropics?

66. Designing ecological and biodiversity sampling strategies. Towards mainstreaming climate change in grassland management.

67. Participatory Poverty and Livelihood Assessment Report, Kalahan, Nueva Vizcaya, the Philippines

68. An Assessment of the Potential for Carbon Finance in Rangelands

69. ECA Trade-offs Among Ecosystem Services in the Lake Victoria Basin.

70. Le business plan d'une petite entreprise rurale de production et de commercialisation des plants des arbres locaux. Cas de quatre pépinières rurales au Cameroun.

71. Les unités de transformation des produits forestiers non ligneux alimentaires au Cameroun. Diagnostic technique et stratégie de développement Honoré Tabuna et Ingratia Kayitavu.

72. Les exportateurs camerounais de safou (Dacryodes edulis) sur le marché sous régional et international. Profil, fonctionnement et stratégies de développement.

73. Impact of the Southeast Asian Network for Agroforestry Education (SEANAFE) on agroforestry education capacity. 
74. Setting landscape conservation targets and promoting them through compatible land use in the Philippines.

75. Review of methods for researching multistrata systems.

76. Study on economical viability of Jatropha curcas L. plantations in Northern Tanzania Assessing farmers' prospects via cost-benefit analysis

77. Cooperation in Agroforestry between Ministry of Forestry of Indonesia and International Center for Research in Agroforestry

78. "China's bioenergy future. an analysis through the Lens if Yunnan Province

79. Land tenure and agricultural productivity in Africa: A comparative analysis of the economics literature and recent policy strategies and reforms

80. Boundary organizations, objects and agents: linking knowledge with action in agroforestry watersheds

81. Reducing emissions from deforestation and forest degradation (REDD) in Indonesia: options and challenges for fair and efficient payment distribution mechanisms

82. Mainstreaming Climate Change into Agricultural Education: Challenges and Perspectives.

83. Challenging Conventional mindsets and disconnects in Conservation: the emerging role of eco-agriculture in Kenya's Landscape Mosaics.

84. Lesson learned RATA garut dan bengkunat: suatu upaya membedah kebijakan pelepasan kawasan hutan dan redistribusi tanah bekas kawasan hutan.

85. The emergence of forest land redistribution in Indonesia.

86. Commercial opportunities for fruit in Malawi.

87. Status of fruit production processing and marketing in Malawi.

88. Fraud in tree science.

89. Trees on farm: analysis of global extent and geographical patterns of agroforestry

90. The springs of Nyando: water, social organization and livelihoods in Western Kenya.

91. Building cpacity toward region-wide curriculum and teaching materials development in agroforestry education in Southeast Asia.

92. Overview of Biomass Energy Technology in Rural Yunnan.

93. A Pro-Growth Pathway for Reducing Net GHG Emissions in China 

The World Agroforestry Centre is an autonomous, non-profit research organization whose vision is a rural transformation in the developing world where smallholder households strategically increase their use of trees in agricultural landscapes to improve their food security, nutrition, income, health, shelter, energy resources and environmental sustainability. The Centre generates science-base knowledge about the diverse role that trees play in agricultural landscapes, and uses its research to advance policies and practices that benefit the poor and the environment.

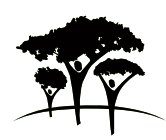

United Nations Avenue, Gigiri - PO Box 30677 - 00100 Nairobi, Kenya Tel: +254207224000 or via USA +1 6508336645 Fax: +254207224001 or via USA +16508336646 Southeast Asia Regional Programme - Sindang Barang, Bogor 16680 PO Box161 Bogor 16001, Indonesia

Tel: +62 251625415 - Fax: +62 251625416

www.worldagroforestry.org 